\section{To: (Receiving Organization)}

Distribution

5. Proj./Prog./Dept./Div.:

8. Originator Remarks:

For approval and release

11. Receiver Remarks:
3. From: (Originating Organization)

G. T. MacLean

6. Design Authority/Design Agent/Cog. Engr.:
4. Related EDT No.:

NA

7. Purchase Order No:

NA

9. Equip./Component No::

NA

10. System/BIdg./Facility:

NA

12. Major Assm. Dwg. No.:

NA

13. Permit/Permit Application No.:

NA

14. Required Response Date:

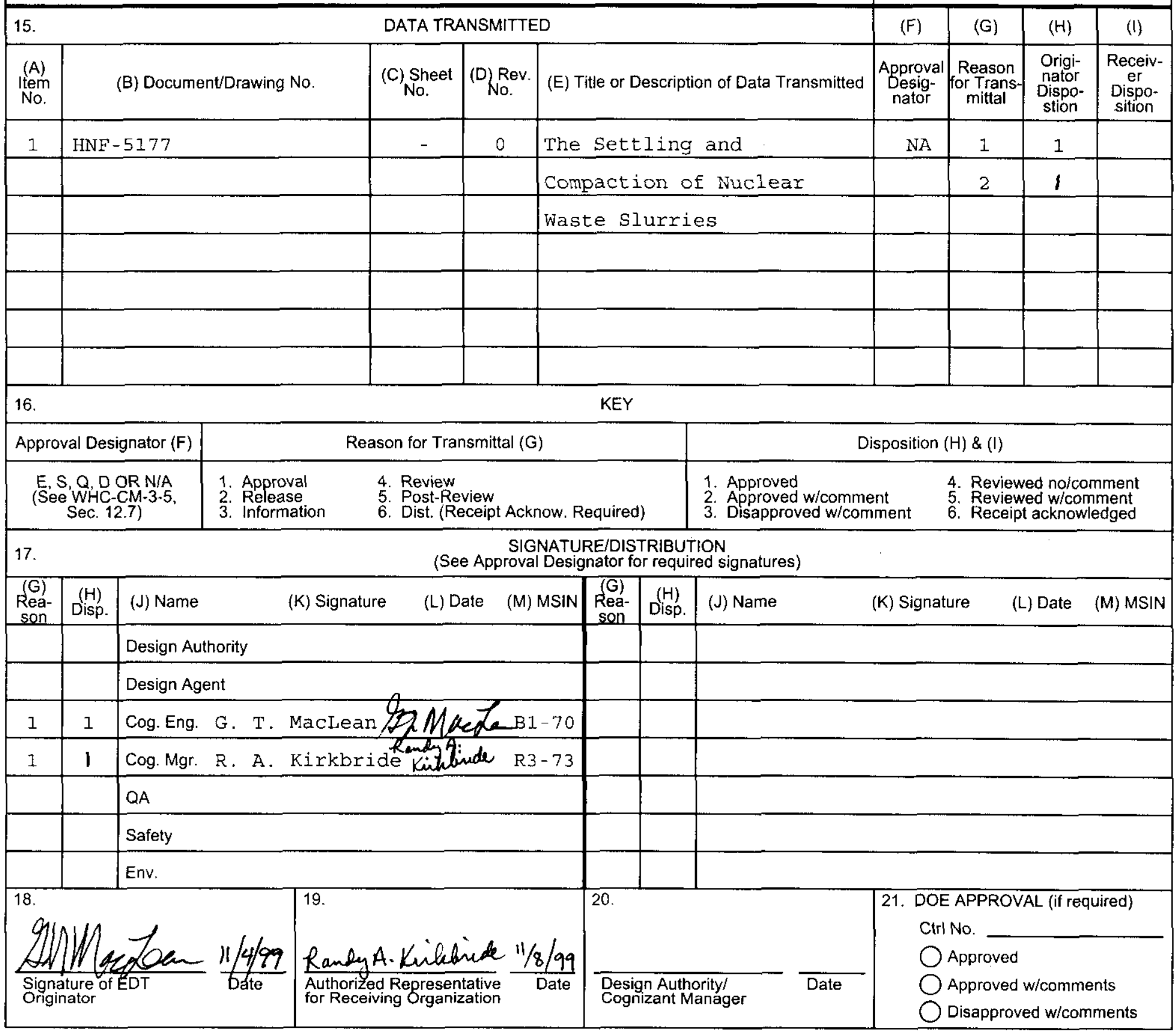




\title{
The Settling and Compaction of Nuclear Waste Slurries
}

\section{G. T. MacLean}

Fluor Daniel Northwest, Richland, WA 99352

Richland, WA 99352

U.S. Department of Energy Contract DE-AC06-96RL.13200

\begin{tabular}{|c|c|c|c|}
\hline EDT/ECN: & 625294 & UC: $\quad N A$ & \\
\hline $\begin{array}{l}\text { Org Code: } \\
\text { B\&R Code: }\end{array}$ & SF8C0 & $\begin{array}{l}\text { Charge Code: } \\
\text { Total Pages: }\end{array}$ & $106436 / A$ A20 faH $H L M O 3 i 1$ \\
\hline
\end{tabular}

Key Words: Sludge, Slurry, Settling, Compaction, Consolidation, Metal Hydroxide, Nuclear Waste, Modeling

\begin{abstract}
The setting and compaction of simulated and real nuclear waste slurries were extensively studied. Experiments were carried out with simulated wastes at laboratory and large-scale sizes, and the results compared. A model of settling was derived and a method developed to correlate and scale-up settling data for different slurries and vessel sizes.
\end{abstract}

TRADEMARK DISCLAIMER. Reference herein to any specific commercial product, process, or service by trade name, trademark, manufacturer, or otherwise, does not necessarily constitute or imply its endorsement, recommendation, or favoring by the United States Government or any agency thereof or its contractors or subcontractors.

Printed in the United States of America. To obtain copies of this document, contact: Document Control Services, P.O. Box 950, Mailstop H6-08, Richland WA 99352, Phone (509) 372-2420; Fax (509) 376-4989.
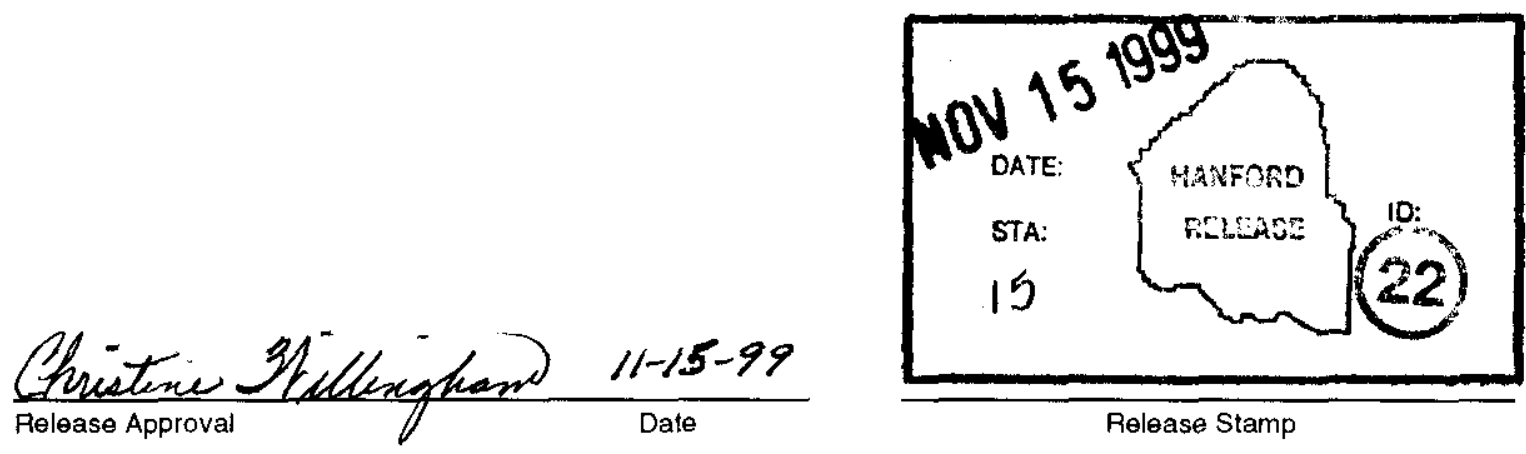

Approved For Public Release 


\title{
The Settling and Compaction of Nuclear Waste Slurries
}

October 1999

\author{
G. T. MacLean \\ Fluor Daniel Northwest \\ Richland, Washington
}

Prepared for

Numatec Hanford Corporation

Richland, Washington 
HNF-5177, Rev. 0

Blank Page 


\section{TABLE OF CONTENTS}

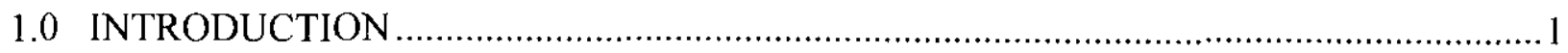

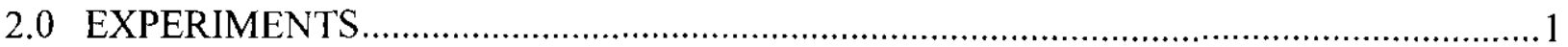

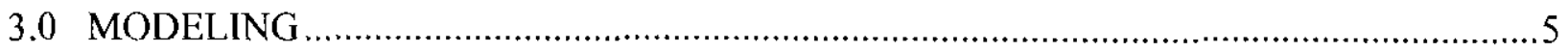

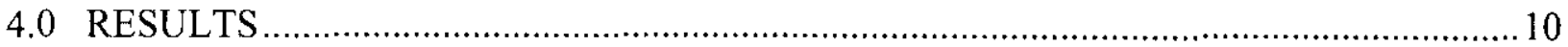

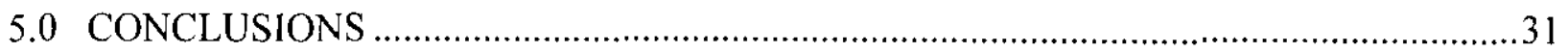

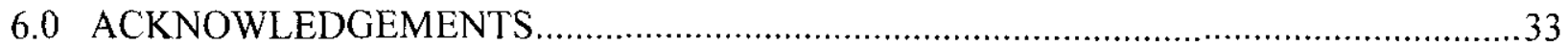

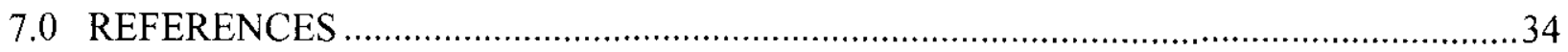

Appendix A Simulated Waste Settling Tests ........................................................ A-1

Appendix B Tank Waste Settling Tests ................................................................. B-1

Pacific Northwest National Laboratory Miniplant

Appendix C Tank Waste Settling Tests ...................................................................... C-1

Pacific Northwest National Laboratory Small Scale 


\section{List of Figures}

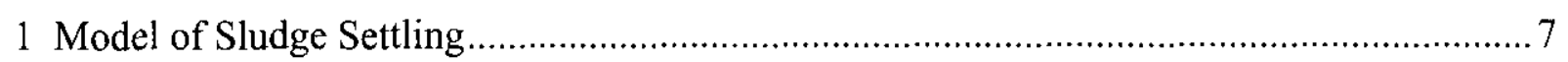

2 Sludge Settling - Diluted $\mathrm{Al}(\mathrm{OH})_{3}-\mathrm{Fe}_{3}(\mathrm{OH})_{3}$ Slurry ....................................................... 11

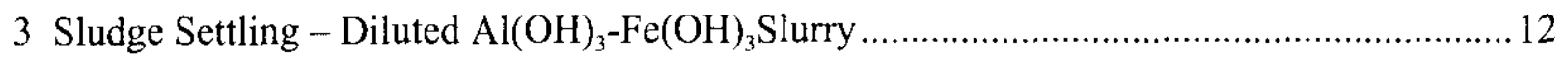

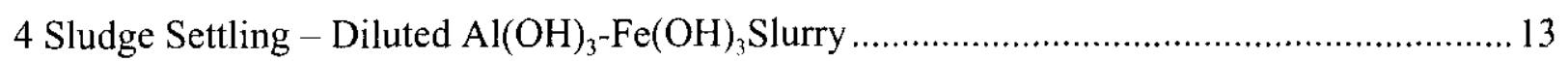

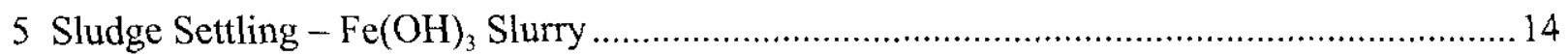

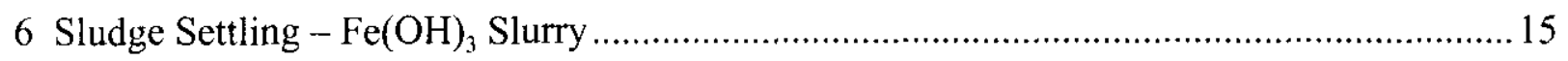

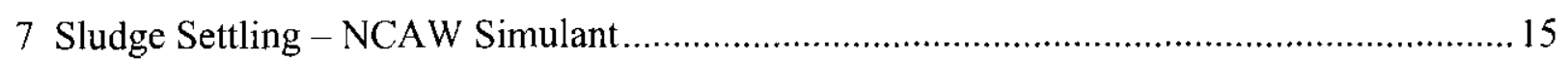

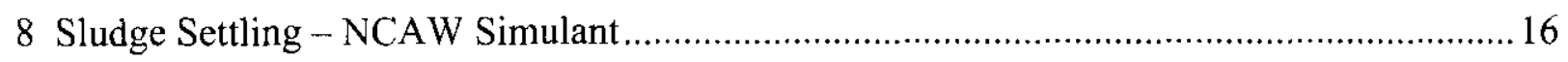

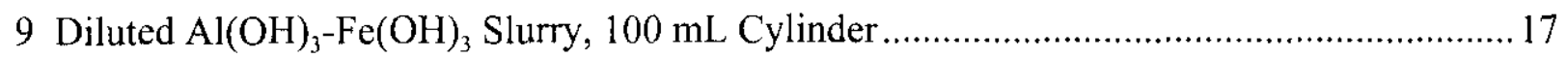

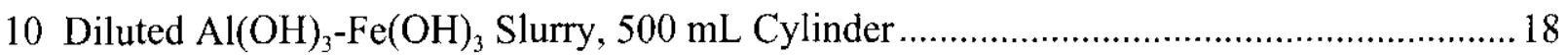

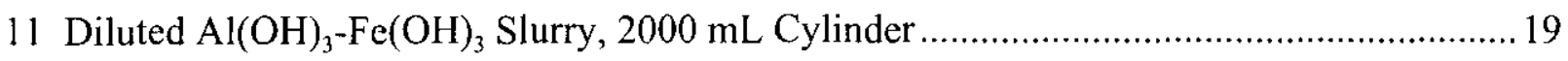

12 Diluted $\mathrm{Al}(\mathrm{OH})_{3}-\mathrm{Fe}(\mathrm{OH})_{3}$ Slurry, $30 \mathrm{Ft}$. Column ......................................................... 19

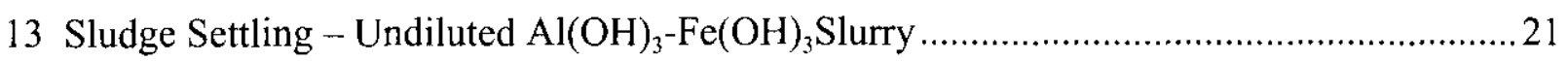

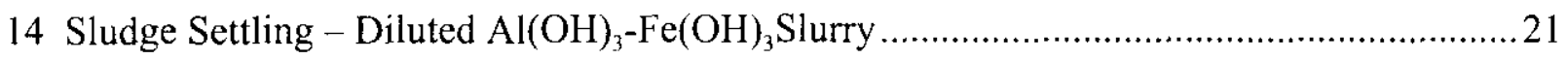

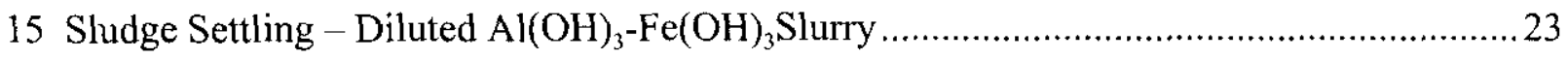

16 Dimensionless Settling Curve - Diluted $\mathrm{Al}(\mathrm{OH})_{3}-\mathrm{Fe}(\mathrm{OH})_{3}$ Slurry ...................................24

17 Dimensionless Settling Curve - Diluted $\mathrm{Al}(\mathrm{OH})_{3}-\mathrm{Fe}(\mathrm{OH})_{3}$ Slurry ...................................2

18 Sludge Concentration - Undiluted $\mathrm{Al}(\mathrm{OH})_{3}-\mathrm{Fe}(\mathrm{OH})_{3}$ Slurry ..........................................2

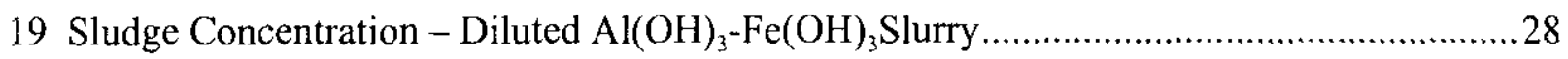

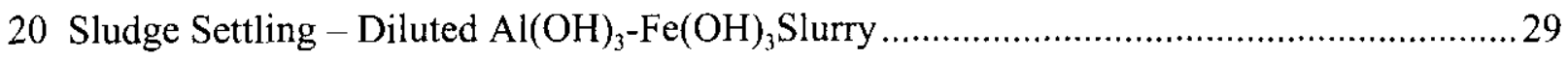

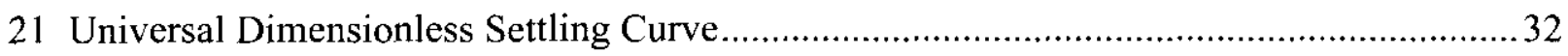

(from $30 \mathrm{ft}$. diluted $\mathrm{Al}(\mathrm{OH})_{3}-\mathrm{Fe}(\mathrm{OH})_{3}$ slurry test) 
HNF-5177, Rev. 0

\section{List of Tables}

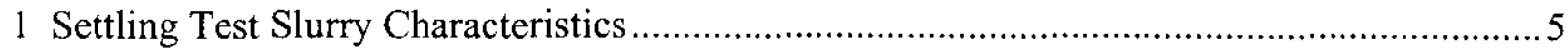

2 Maximum Settling Velocities of Real and Simulated Wastes ………....................................30 
HNF-5177, Rev. 0

\section{Blank Page}


HNF-5177, Rev. 0

\section{THE SETTLING AND COMPACTION OF NUCLEAR WASTE SLURRIES}

\subsection{INTRODUCTION}

The settling and compaction characteristics of slurries are important physical phenomena in the retrieving, processing, and transferring of nuclear wastes stored in underground tanks. It is important to be able to predict the height of the slurry-supernatant interface layer as a function of time as it settles. It is also important to be able to predict the insoluble solids concentration of the sludge, so the relationship between sludge level and total amount of insoluble solids can be determined. Considerable data exists from short-term experiments with simulated and real waste sludges at the laboratory scale, but there are no data for long settling times or at the scale of the U. S. Department of Energy nuclear waste storage tanks. Most of these tanks can contain up to 30 feet of waste.

The work reported here included experimental settling and compaction studies and modeling of the sludge settling process. In order to be able to scale laboratory data to full tank height, experiments were conducted with simulated waste slurries at both laboratory and full tank depth scales. The tests were continued for about nine months so that the long-term compaction phenomena could be observed. Data from these tests and previous tests by other investigators with real and simulated waste were analyzed to answer the following questions:

1. What is the effect of vessel size and geometry on the settling phenomena?

2. Does the thickness of the sludge layer during the compaction stage affect the rate or final extent of compaction?

3. Does the particle concentration at the bottom of the vessel increase more rapidly than the average slurry layer concentration?

4. How do the settling phenomena vary from one waste to another?

In order to facilitate scale-up, a sludge-settling model was developed and used for correlating settling test results.

\subsection{EXPERIMENTS}

Laboratory scale experiments were conducted in $100 \mathrm{~mL}, 500 \mathrm{~mL}$, and $2 \mathrm{~L}$ graduated cylinders with several different waste simulant slurries. Full tank depth experiments were conducted in 32 $\mathrm{ft}$. high columns that contained $30 \mathrm{ft}$. of slurry. A one-ft. in diameter by $32-\mathrm{ft}$. high column was constructed in Bldg. 305, and later a 32-ft. by 10 -inch diameter column was constructed in Bldg. 306E, both on the U. S. Department of Energy Hanford Site. A picture of the Bldg. 306 column and slurry mixing tank is shown on the next page. The lower portion of the column, which extended through the floor into a lower room, is not shown. 
HNF-5177, Rev. 0

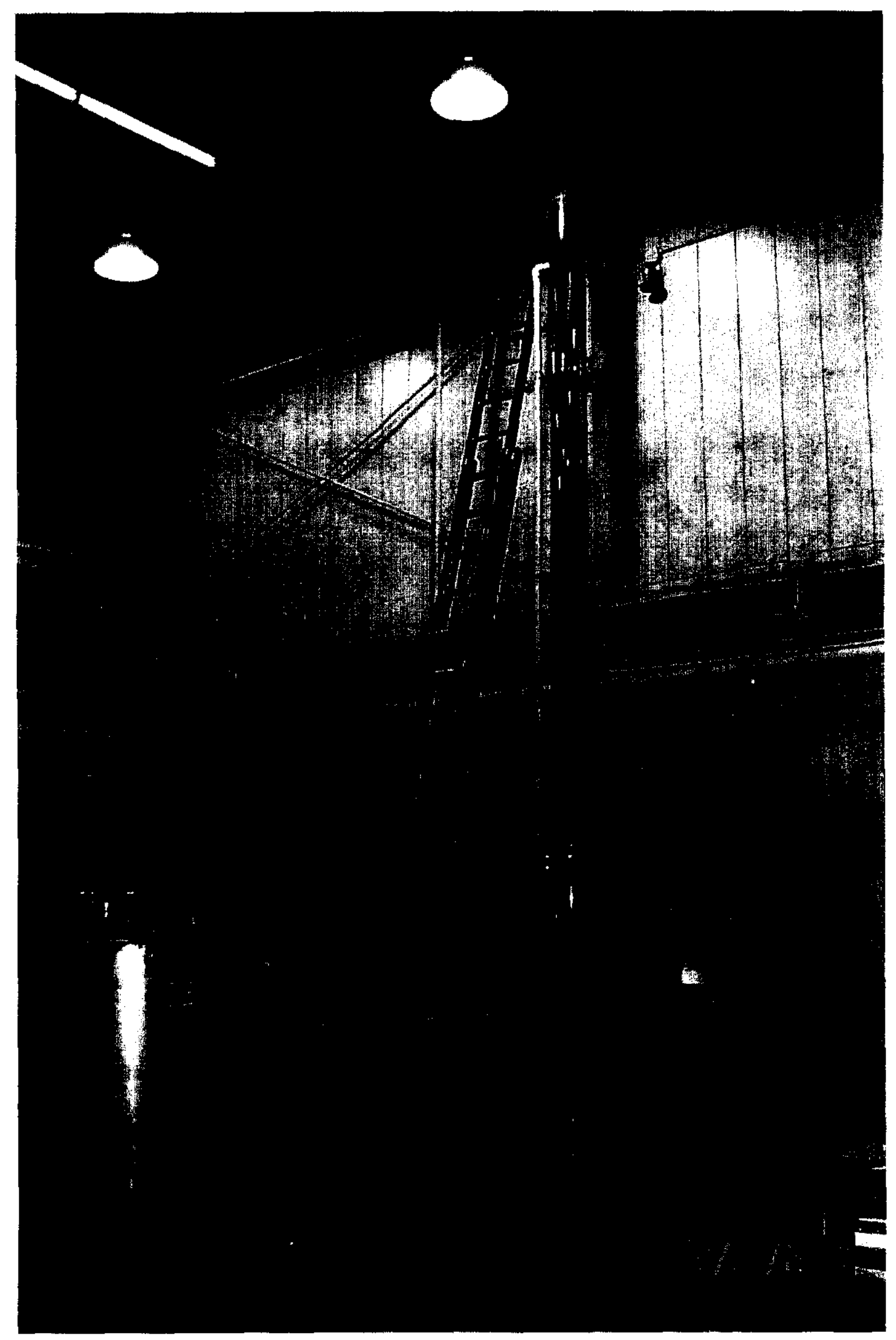


The first full height column was made of flanged four-foot sections of clear polyvinyl chloride (PVC), while the second column was made of two sections of clear polyacrylate plastic. Both columns allowed viewing of the slurry-supernatant interface level and the physical appearance of the slurry and liquid. Also, both columns had the same Ohmart nuclear density gauge mounted about six inches from the bottom of the inside of the column. This gauge was calibrated at the factory for the Bldg. 305 column and for slurries containing ferric hydroxide in 6 percent sodium nitrate solution.

In the first full height test, conducted in Bldg. 305, a slurry that had been used for testing a sludge interface analyzer instrument was used. Two thousand gallons of this slurry was made by dissolving hydrated ferric nitrate in water, then raising the $\mathrm{pH}$ to about 12 by adding $50 \mathrm{wt} . \%$ sodium hydroxide. Some of the water came from a lime slurry, and therefore contained some dissolved calcium and magnesium. The properties of the slurry used in the test were as follows:

$\begin{array}{lc}\text { Slurry Total Dried Solids } & 6.4 \mathrm{wt} \% \\ \text { Solution Total Dissolved Solids } & 5.8 \mathrm{wt} \% \\ \text { Dried Insoluble Solids (calculated) } & .63 \mathrm{wt} \% \\ \text { Dried Insoluble Solids (filtered) } & .43 \mathrm{wt} \%\end{array}$

The insoluble solids value was calculated from the total and dissolved solids values, which in turn were determined in an automatic infrared drying apparatus. The insoluble solids value by filtration was determined gravimetrically by vacuum filtering a sample through a $.45 \mu \mathrm{m}$ poresize filter, washing with water once, and then drying at $105^{\circ} \mathrm{C}$. This slurry is referred to as the $\mathrm{Fe}(\mathrm{OH})_{3}$ slurry.

For the second and third tests, conducted in Bldg. 306E, 200 gallons of slurry was made up by dissolving equal moles of hydrated ferric nitrate and hydrated aluminum nitrate in water, then adding $50 \mathrm{wt} \% \%$ sodium hydroxide until a $\mathrm{pH}$ of about 12 was reached. The composition of the base slurry used in these test was as follows:

$\begin{array}{ll}\mathrm{Fe}(\mathrm{OH})_{3} & 4.46 \mathrm{wt} . \% \\ \mathrm{Al}(\mathrm{OH})_{3} & 3.25 \mathrm{wt} \% \\ \mathrm{NaNO}_{3} & 21.2 \mathrm{wt} \% \\ \text { Slurry Total Dried Solids (measured) } & 30.5 \mathrm{wt} \% \\ \text { Solution Total Dissolved Solids (measured) } & 24.9 \mathrm{wt} \% \\ \text { Dried Insoluble Solids (calculated) } & 7.46 \mathrm{wt} \% \\ \text { Solution Density } & 1.175 \mathrm{~g} / \mathrm{L} \\ \text { Slurry Density } & 1.20 \mathrm{~g} / \mathrm{L}\end{array}$

The chemical concentrations are based on the measured amount of chemicals used to make up the slurry, while the total and dissolved solids are the results of analyses performed as described above for the Bldg. 305 slurry. For the second full-scale test, the above slurry was used as mixed. For the third test, the slurry was diluted with sodium nitrate solution to give a slurry with the same liquid total dissolved solids but with an insoluble solids concentration equal to about 
$50 \%$ of the undiluted slurry. These slurries are referred to as the undiluted and diluted $\mathrm{Al}(\mathrm{OH})_{3^{-}}$ $\mathrm{Fe}(\mathrm{OH})_{3}$ slurries.

Four simulants were used in the laboratory bench scale testing: the three mentioned above and a Neutralized Current Acid Waste (NCAW) simulant. This slurry was synthesized to simulant the NCAW (sometimes referred to as "aging waste") produced by the PUREX process for recovering uranium and plutonium from irradiated uranium fuel. ${ }^{1}$ The approximate composition of this slurry is shown below:

$\begin{array}{ll}\mathrm{NaNO} 3 & 14 \mathrm{G} / \mathrm{L} \\ \mathrm{Al}\left(\mathrm{NO}_{3}\right)_{3} \cdot 9 \mathrm{H}_{2} \mathrm{O} & 240 \mathrm{G} / \mathrm{L} \\ \mathrm{Fe}\left(\mathrm{NO}_{3}\right)_{3} \cdot 9 \mathrm{H}_{2} \mathrm{O} & 33 \mathrm{G} / \mathrm{L} \\ \mathrm{Fe}_{2}\left(\mathrm{SO}_{4}\right)_{3} \cdot 9 \mathrm{H}_{2} \mathrm{O} & 24 \mathrm{G} / \mathrm{L} \\ \mathrm{Cr}_{2}\left(\mathrm{NO}_{3}\right)_{3} \cdot 9 \mathrm{H}_{2} \mathrm{O} & 5 \mathrm{G} / \mathrm{L} \\ \mathrm{SiO}_{2} & .5 \mathrm{G} / \mathrm{L} \\ \mathrm{Ni}\left(\mathrm{NO}_{3}\right)_{2} \cdot 6 \mathrm{H}_{2} \mathrm{O} & 19 \mathrm{G} / \mathrm{L} \\ \mathrm{ZrO}\left(\mathrm{NO}_{3}\right)_{2} & 1.2 \mathrm{G} / \mathrm{L} \\ \mathrm{K}_{2} \mathrm{CO}_{3} & 8.3 \mathrm{G} / \mathrm{L}\end{array}$

In addition to the above chemicals, $\mathrm{HNO}_{3}, \mathrm{H}_{2} \mathrm{SO}_{4}, \mathrm{HF}, \mathrm{NaOH}$, and sucrose solutions were added to adjust $\mathrm{pH}$, composition, and denitrate the solution during the preparation of the simulant.

The volume \% centrifuged sludge, the weight $\%$ water in the slurry, supernatant liquid, and centrifuged liquid, and the supernatant liquid density of the four slurries were measured. The volume of sludge was determined by centrifuging $50 \mathrm{~mL}$ of well-mixed slurry sample at the slowest speed $(500 \mathrm{rpm})$ until no more change in sludge volume was observed. This was done to approximate the ultimate settled sludge volume condition. The volume \% sludge was obtained by dividing the volume of the centrifuged sludge by the total volume of the centrifuged sludge and liquid $(50 \mathrm{~mL})$.

The weight percent water was determined with an automatic instrument that heats about a 5 gram sample slowly up to $120^{\circ} \mathrm{C}$, then maintains this temperature until a steady weight is obtained. The densities were measured at $22^{\circ} \mathrm{C}$. The results of the analyses for all the slurries are shown in Table 1 . The results for the undiluted $\mathrm{Al}(\mathrm{OH})_{3}-\mathrm{Fe}(\mathrm{OH})_{3}$ are slightly different than previously shown; the former were measured at the beginning of the testing, and the latter almost two years later at the end of the testing. 
HNF-5177, Rev. 0

Table 1

Settling Test Slurry Characteristics

\begin{tabular}{|l|c|c|c|c|}
\hline \multicolumn{1}{|c|}{$\begin{array}{c}\text { Property } \\
\text { Measured }\end{array}$} & $\begin{array}{c}\text { NCAW Simulant } \\
\text { Slurry }\end{array}$ & $\mathrm{Fe}(\mathrm{OH})_{3}$ Slurry & $\begin{array}{c}\text { Undiluted } \\
\mathrm{Fe}(\mathrm{OH})_{3} / \mathrm{Al}(\mathrm{OH})_{3} \\
\text { Slurry }\end{array}$ & $\begin{array}{c}\text { Diluted Fe(OH) } \\
\mathrm{Al}(\mathrm{OH})_{3} \text { Slurry }\end{array}$ \\
\hline $\begin{array}{l}\text { Cent. Sludge, } \\
\text { vol.\% }\end{array}$ & $15 \%$ & $26 \%$ & $31 \%$ & $18 \%$ \\
\hline $\begin{array}{l}\text { Water in Slurry, } \\
\text { wt.\% }\end{array}$ & $64.1 \%$ & $91.5 \%$ & $68.9 \%$ & $71.7 \%$ \\
\hline $\begin{array}{l}\text { Water in Super. } \\
\text { Liquid, wt.\% }\end{array}$ & $71.5 \%$ & $93.6 \%$ & $75.3 \%$ & $75.1 \%$ \\
\hline $\begin{array}{l}\text { Water in Cent. } \\
\text { Liquid, wt.\% }\end{array}$ & - & $93.3 \%$ & $73.0 \%$ & $73.3 \%$ \\
\hline $\begin{array}{l}\text { Liquid Density, } \\
\text { grams/liter }\end{array}$ & 1230 & 1044 & 1174 & 1175 \\
\hline $\begin{array}{l}\text { Insoluble Solids, } \\
\text { wt.\% (calculated) }\end{array}$ & $11.5 \%$ & $2.1 \%$ & $7.1 \%$ & $4.7 \%$ \\
\hline
\end{tabular}

The insoluble solids concentrations were calculated using the wt. \% water in supernatant liquid values and the following formula:

$$
w t . \% \text { insoluble solids }=100\left(\frac{w t . \% \text { water in solution }- \text { wt. } \% \text { water in slurry }}{w t . \% \text { water in slurry }}\right)
$$

The above formula was derived from the formula below by substituting variables:

$$
w t . \% \text { insoluble solids }=w t . \% \text { total solids }-w t . \% \text { dissolved solids }\left(\frac{w t . o f \text { solution }}{w t . o f \text { slurry }}\right)
$$

The variation in measured \% water in supernatant liquid and centrifuged liquid indicate the measurements or method may not be very accurate. Since the wt. \% insoluble solids is calculated from the difference in two wt. \% water measurements, this result may be even less accurate. The value for insoluble solids concentration in the NCAW simulant does not agree well with previous measurements of the same slurry. ${ }^{2}$ In the previous work, the insoluble solids concentration was measured by filtration to be about $4 \mathrm{wt}$. \%. Although it is not certain that the slurry concentration was the same in both studies, it was not expected to be much different. It is best to make three determinations of each property, and average the results, as is generally recommended in analysis of wastewater. ${ }^{3}$

\subsection{MODELING}

Considerable time and effort has been expended at the Hanford site and other locations studying the settling behavior of storage tank wastes and simulants of waste. However, the data has been presented as settling curves which do not lend themselves to scale-up or comparison. An 
important goal of this work was to develop a method and the necessary data for scaling laboratory settling test results to tank scale. Presented here is the derivation of a continuity equation that describes settling behavior and the derivation of dimensionless parameters that characterize the settling phenomena. A standard way of plotting and fitting settling data is recommended so that it can be used for scale-up or comparison with data from different investigators.

A macroscopic continuity (conservation of mass) equation to describe settling can be derived by making a mass balance across an infinitely thin horizontal slice through a constant cross section area vessel. This derivation is valid for beakers, graduated cylinders, columns, and tanks of any size, as long as:

1. The vessel cross section area doesn't change with height

2. Gravitational force is the only external force acting on the particles

3. The vessel sides are parallel to the gravitational force vector

As shown in Fig. 1, a control volume can be defined as the cross section area times a small axial distance. The mass balance for this control volume is:

$$
\text { accumulation }=\text { mass in }- \text { mass out }
$$

or in mathematical terms,

$$
\mathrm{A} \frac{\Delta \mathrm{z} \Delta \mathrm{c}}{\Delta \mathrm{t}}=(\mathrm{vAc})_{\text {in }}-(\mathrm{vAc})_{\text {out }}
$$

in which $\quad \mathrm{A}=$ vessel cross section area

$\mathrm{Z}=$ distance from bottom of vessel

$\mathrm{c}=$ particle volumetric concentration averaged across the cross section

$\mathrm{t}=$ time since commencement of settling

$\mathrm{v}=$ particle velocity averaged across the cross section 
HNF-5177, Rev. 0

Figure 1

Model of Sludge Settling

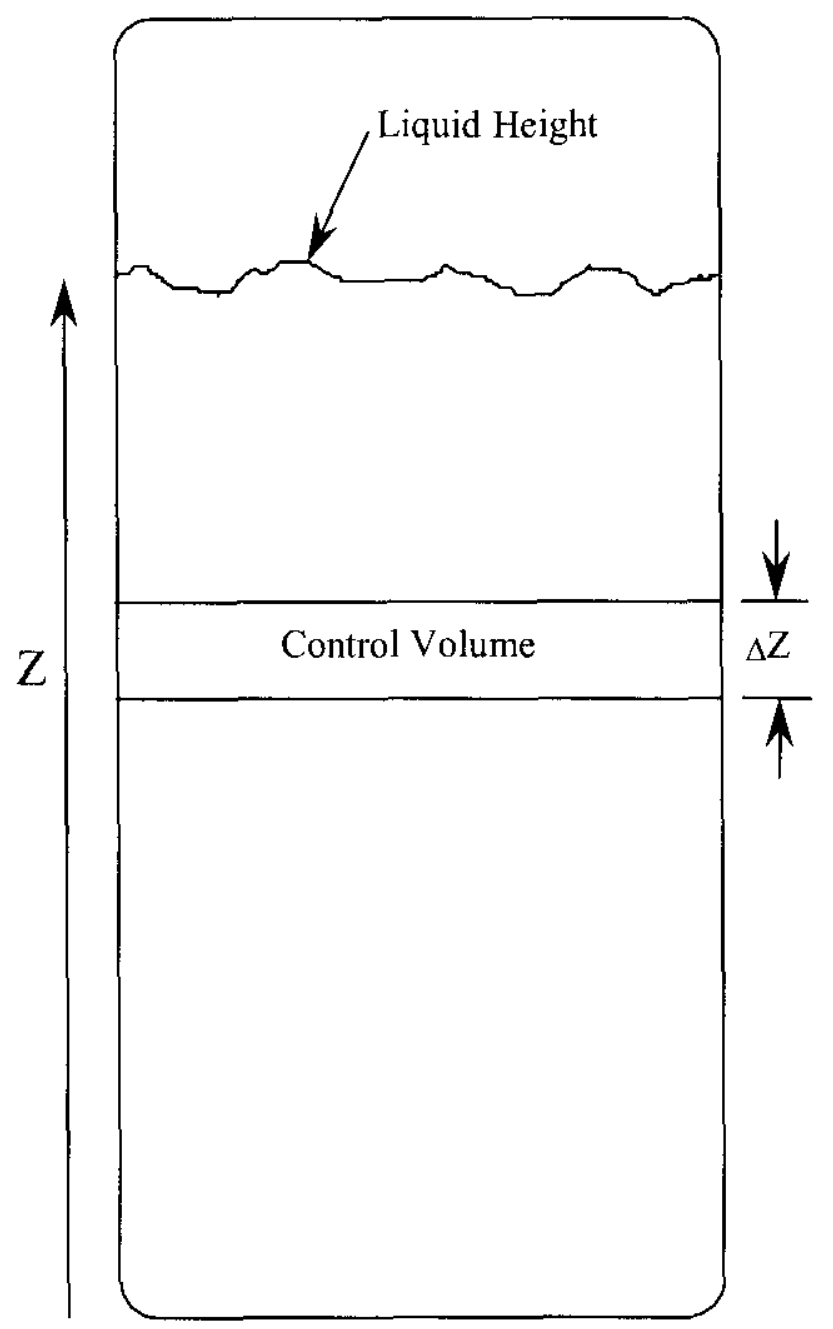

Equation 1 can be rearranged to give

$$
\frac{\Delta \mathrm{c}}{\Delta \mathrm{t}}=\frac{(\mathrm{vc})_{\text {in }}-(\mathrm{vc})_{\text {out }}}{\Delta \mathrm{z}}
$$

If $\Delta \mathrm{z}$ and $\Delta \mathrm{t}$ are made infinitesimally small, Equation 2 becomes the following differential equation:

$$
\frac{\partial c}{\partial t}=\frac{\partial(v c)}{\partial z}=v \frac{\partial c}{\partial z}+c \frac{\partial v}{\partial z}
$$

The key part of this derivation is to make the differential continuity equation dimensionless by normalizing the variables with parameters characteristic of the system. It is important that the 
variables have a value of zero or one at characteristic times $\left(\mathrm{t}^{*}=0\right.$ and $\left.\mathrm{t}^{*}=\infty\right)$, so that for any system a normalized plot will pass through these characteristic points. This will be done by defining the following variables and substituting them into equation 3 :

$$
\mathrm{c}^{*}=\frac{\mathrm{c}}{\mathrm{c}_{\mathrm{m}}}, \mathrm{v}^{*}=\frac{\mathrm{v}}{\mathrm{v}_{\mathrm{m}}}, \mathrm{z}^{*}=\frac{\mathrm{z}}{\mathrm{z}_{\mathrm{m}}}
$$

The characteristic concentration $\mathrm{c}_{\mathrm{m}}$ is the maximum compacted sludge concentration that can be achieved by long term settling. This concentration can be estimated by centrifuging a slurry sample as slow as possible and determining the insoluble solids concentration in the resulting cake. The characteristic height $\mathrm{z}_{\mathrm{m}}$ is the sludge height at maximum compaction, or infinite settling time.

The characteristic velocity $\mathrm{v}_{\mathrm{m}}$ is the particle apparent maximum or free settling velocity. This free settling velocity is estimated by performing a settling test with slurry dilute enough to give a settling curve in which the initial part is linear. The slope of this linear portion is the apparent free settling velocity. If the slurry contains particles that settle at different rates, the slope will be the velocity for the top of the slurry layer, and not necessarily for the fastest settling particles. For a slurry that, upon initiation of settling, rapidly forms a clear supernatant with a definite slurry-liquid interface, most particles are settling en masse at the same rate.

Upon substituting the above dimensionless variables into Equation 3, we get

$$
\frac{\partial \mathrm{c}^{*}}{\partial \mathrm{t}^{*}}=\mathrm{v}^{*} \frac{\partial \mathrm{c}^{*}}{\partial \mathrm{z}^{*}}+\mathrm{c}^{*} \frac{\partial \mathrm{v}^{*}}{\partial \mathrm{z}^{*}}
$$

in which $\mathrm{t}^{*}=\frac{\mathrm{v}_{\mathrm{m}} \mathrm{t}}{\mathrm{z}_{\mathrm{m}}}$, the definition of the dimensionless time that makes the continuity equation dimensionless and normalized.

Equation 4 has two dependent variables, $\mathrm{c}^{*}$ and $\mathrm{v}^{*}$, and two independent variables, $\mathrm{t}^{*}$ and $\mathrm{z}^{*}$. Therefore, another equation is needed to relate the dependent variables. An empirical correlation similar to ones commonly used to fit settling observations is

$$
v^{*}=\left(1-c^{*}\right)^{k}
$$

in which $\mathrm{k}$ is a constant specific to the mixture and related to the Reynolds Number for the particles. ${ }^{4}$ If this correlation is substituted into Equation 4, we obtain

$$
\frac{\partial c^{*}}{\partial t^{*}}=\left(1-c^{*}\right)^{k} \frac{\partial c^{*}}{\partial z^{*}}-k c^{*}\left(1-c^{*}\right)^{k-1} \frac{\partial c^{*}}{\partial z^{*}}
$$

Now we have one equation with one dependent variable $\left(\mathrm{c}^{*}\right)$, two independent variables $\left(\mathrm{t}^{*}\right.$ and $\mathrm{Z}^{*}$ ), and one parameter $\mathrm{k}$. In principle, Equation 5 is solvable if appropriate initial and boundary conditions are specified. The real value, however, of Equation 5 is it indicates that for all 
systems that satisfy the conditions of validity for the continuity equation, and have the same initial dimensionless concentration and value of $\mathrm{k}$, the settling curve will be the same if plotted in terms of the dimensionless variables. Thus, if the settling correlation is valid, the settling characteristics are determined by the values of $\mathrm{v}_{\mathrm{m}}, \mathrm{c}_{\mathrm{m}}, \mathrm{z}_{\mathrm{m}}, \mathrm{k}$ and the initial concentration or slurry height.

Most often, particle concentrations are not measured during settling experiments because of the difficulty of getting representative samples without disrupting the settling process. Only the slurry-liquid interface height is measured as a function of time. However, a plot of slurry interface settling data can be made in terms of the dimensionless variables as $\frac{z_{i}}{z_{m}}$ vs. $t^{*}$, in which $z_{\mathrm{j}}$ is the interface height. If the physical and chemical nature of the particles and solution that determine the settling characteristics are the same for several slurries, and the conditions of the above derivation are satisfied, then the dimensionless settling curve will be the same for each at the same initial concentration. This is true for any size waste vessel, provided wall effects are negligible and particle bridging (or the value of $\mathrm{k}$ ) is independent of vessel size and shape. In such cases, a dimensionless plot of laboratory or miniplant settling data can be used to directly scale to full size waste tanks or processing vessels.

One problem with the model discussed above is that scale-up is only valid if the initial insoluble solids concentration is the same at all scales. It would be advantageous if a method of plotting the data could be devised such that scale-up could be done for any initial concentration, as long as the slurry was dilute enough to go through a linear rapid settling period. This would result in one universal settling curve that could be used for all wastes that have the same physical and chemical attributes. Dimensionless variables that achieve this and still lead to the form of Equation 4 are defined below:

$$
\begin{gathered}
z_{i}^{*}=\frac{z_{i}-z_{m}}{z_{m}} \\
t_{0}^{*}=\frac{v_{m}\left(t-t_{0}\right)}{z_{m}}
\end{gathered}
$$

The time offset $t_{o}$ is the time that the interface would take to reach the height $z_{m}$ if the interface velocity remained constant at $\mathrm{v}_{\mathrm{m}}$.

Settling curves for all slurries will have the same normalized slope during the rapid settling period if plotted in terms of the dimensionless variables. The ratio of the initial concentration to the ultimate compacted sludge concentration will determine how large the dimensionless height will be in the negative dimensionless time region. An initial to maximum slurry or sludge layer concentration of 0.1 will translate to a maximum dimensionless interface height of $10.0-1.0$, or 9.0 .

Settling curves for all slurries in any vessel, graphed in terms of the above dimensionless varaibles, will be the same through all stages of settling and compaction, provided that: 
(1) The agglomeration characteristics are the same.

(2) The rate of compaction and intermediate settling have the same proportionality to the rate of rapid settling.

(3) The vessel geometry satisfies the conditions for which the model was developed.

Examples of dimensionaless plots are shown in Figures 16 and 17 in the Results section, and Figure 21 in the Conclusions section. The real time that a slurry will take to settle from an initial well mixed condition to a chosen settled condition can be caluclated using Figure 19 and the following formula:

$$
t_{f}-t_{i}=\frac{z_{m}\left(t_{o f}^{*}-t_{o i}^{*}\right)}{v_{m}}
$$

The subscript " $\mathrm{f}$ " refers to the final state, and "i" refers to the initial state.

\subsection{RESULTS}

As mentioned in the Introduction, data from the experiments discussed previously have been analyzed to answer the following questions:

1. What is the effect of vessel size and geometry on the settling phenomena?

2. Does the thickness of the sludge layer during the compaction stage affect the rate or final extent of compaction?

3. Does the particle concentration at the bottom of the vessel increase more rapidly than the average slurry layer concentration?

4. How do the settling phenomena vary from one waste to another?

The answers to these questions are discussed in the sections that follow.

\section{Effect of Vessel Size and Geometry on Settling Phenomena}

The first question can be answered by comparing the results from the laboratory and $30 \mathrm{ft}$. height settling tests with the $\mathrm{Al}(\mathrm{OH}) 3-\mathrm{Fe}(\mathrm{OH}) 3$ slurries. Shown in Figures 2 and 3 are comparisons of the interface height versus time for the diluted slurry during the early settling period. The "Relative Interface Height" in Figure 3 and later figures is the absolute interface height divided by the initial slurry height. 
HNF-5177, Rev. 0

Figure 2

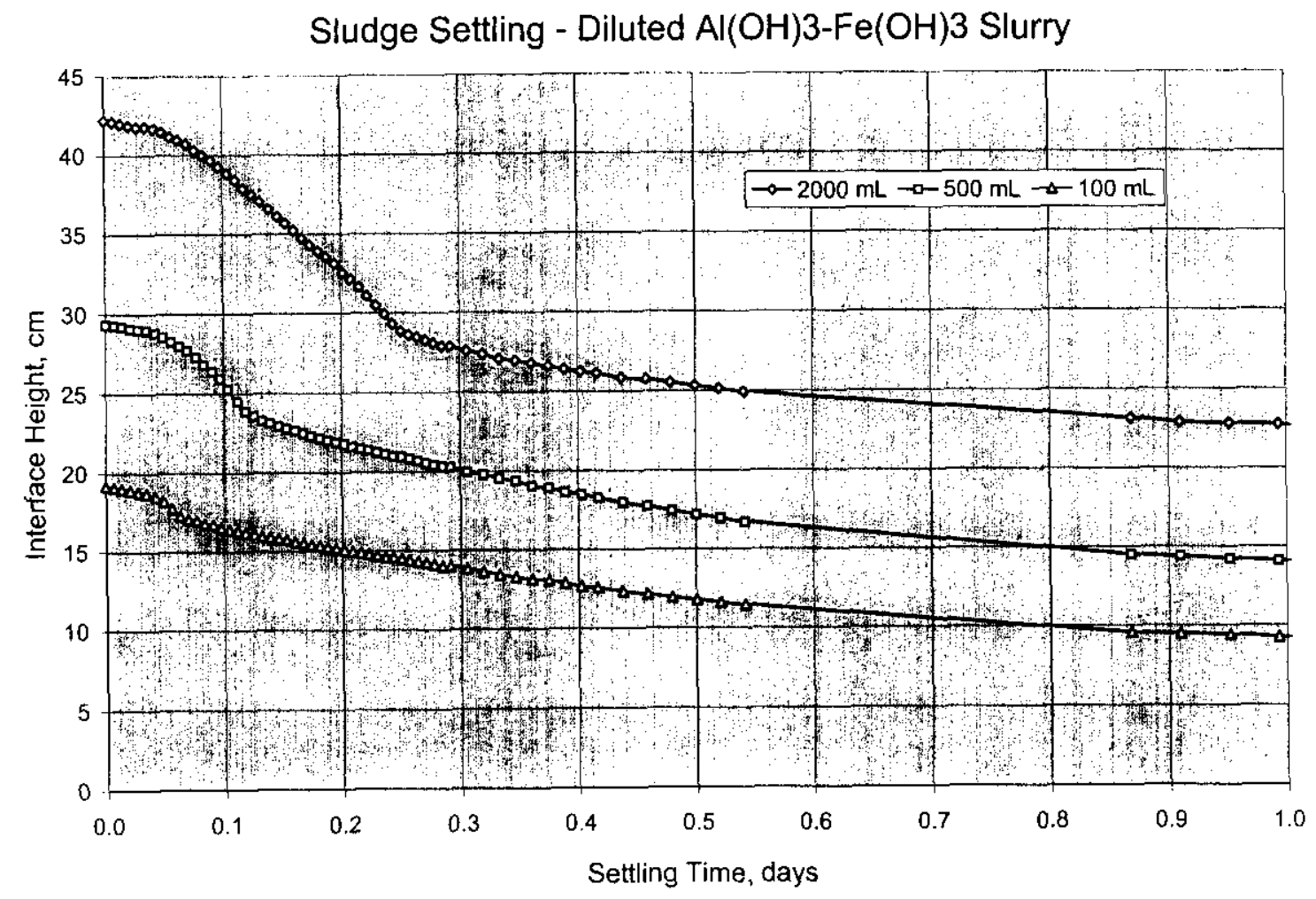


Figure 3

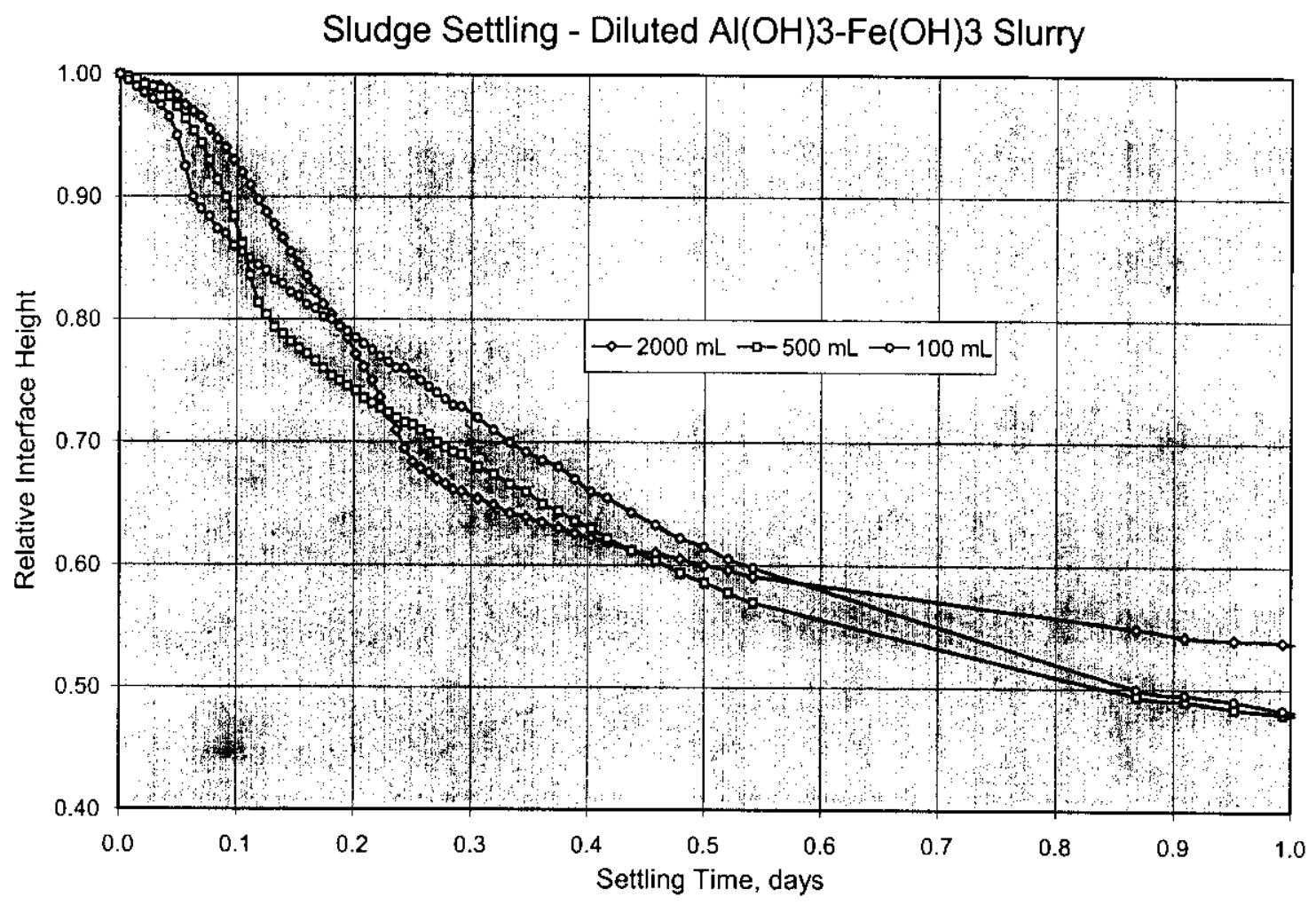

In both Figures 2 and 3, the curve for each of the tests has a different shape than the others. The initial shape looks the same up to about 1.4 hours (.06 days), but after this time, a significant difference occurs. The rate of settling increases substantially, but the duration of this increased rate is different: the larger the cylinder, the longer the duration. In Figure 4, the early period of settling for the $30 \mathrm{ft}$. high column is shown. Notice that the slow settling period last about the same amount of time as in the laboratory test, but that the rapid settling period extends for a much longer period. The differences in the rapid settling period duration are apparently due to the difference in settling height - the greater the axial distance, the longer the time period available for the rapid settling period. 
Figure 4

Sludge Settling - Diluted $\mathrm{Al}(\mathrm{OH}) 3-\mathrm{Fe}(\mathrm{OH}) 3$ Slurry

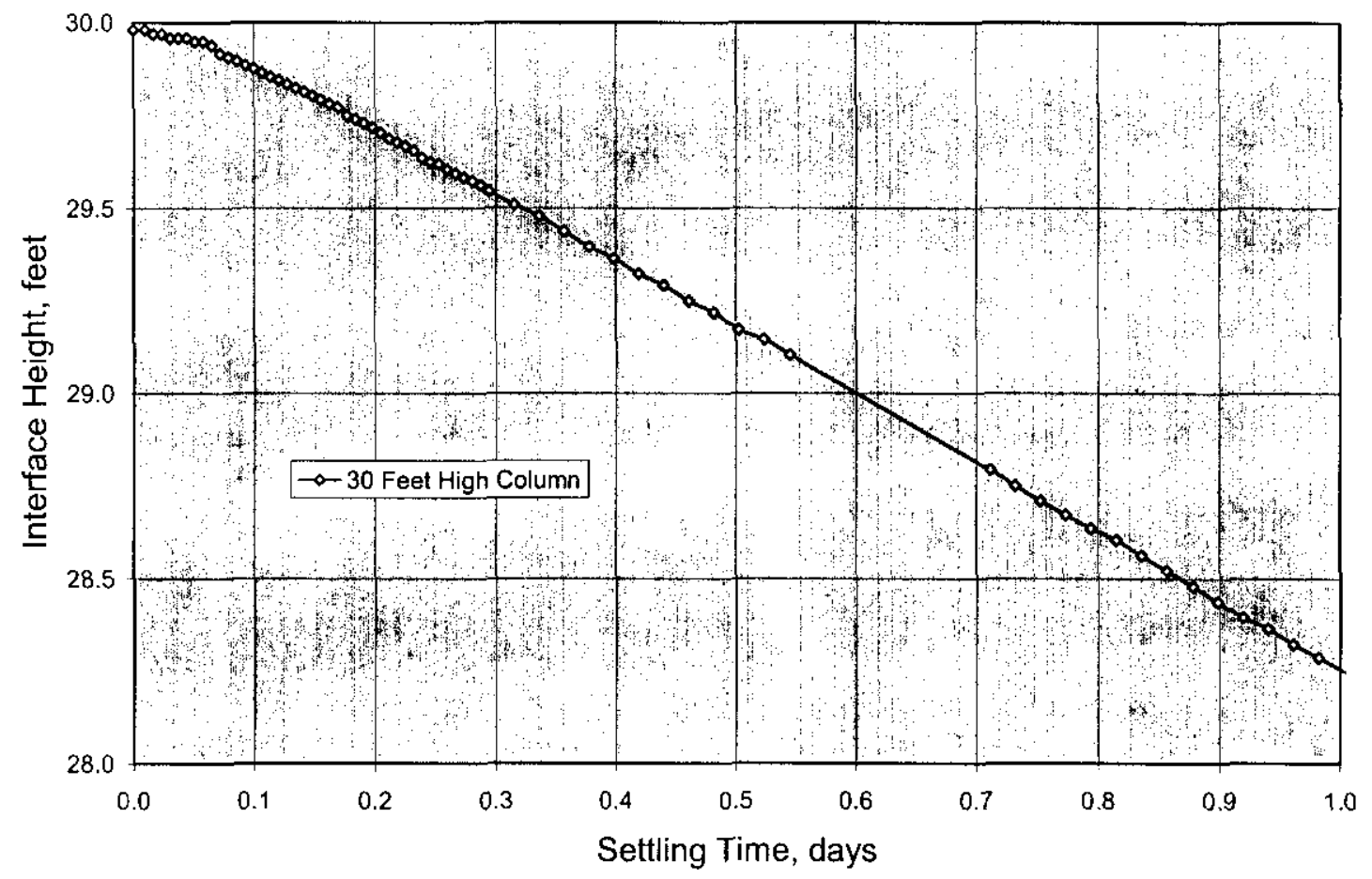

The phenomena discussed above can be explained as follows: At the commencement of settling, mixing of the slurry has been terminated and changes in the particle nature begin occurring. These changes likely involve flocculation or agglomeration, ${ }^{5,6}$ or some type of bridging. During this period, little settling occurs. As a new particle structure becomes stable, the settling rate dramatically increases and becomes more or less constant. This period has been referred to as both free settling and hindered settling. It actually is not free particle settling, as the particles are interacting strongly, but the agglomerates are apparently settling freely. This rapid settling period continues until the concentration of particles at the interface is high enough that the agglomerates begin interacting. Settling begins to slow and the transition to sludge compaction or consolidation occurs.

An initial agglomeration period is apparent in the tests with other slurries, as well as the $\mathrm{Al}(\mathrm{OH})_{3}-\mathrm{Fe}(\mathrm{OH})_{3}$ slurry, although of shorter duration. Graphs of settling data for the $\mathrm{Fe}(\mathrm{OH})_{3}$ slurry are shown in Figures 5 and 6, and for the NCAW slurry in Figures 7 and 8. The $\mathrm{Fe}(\mathrm{OH})_{3}$ slurry appeared to barely reach a rapid settling period in the $100 \mathrm{~mL}$ cylinder, while this period became well developed even in the $100 \mathrm{~mL}$ cylinder with the $\mathrm{NCAW}$ slurry. The $\mathrm{Fe}(\mathrm{OH})_{3}$ slurry formed large, rapid settling flocks and a fluffy sludge, while the NCAW slurry agglomerates were small and the sludge was denser. Apparently, the more chemically complex is the slurry composition, the smaller the agglomerates and the more tightly packed is the sludge. This is reasonable, considering the more complex slurries have a greater variety of particle sizes, shapes, densities, and surface conditions. Most nuclear storage tank wastes with sludges that are mainly metal precipitates are expected to behave like the NCAW slurry. 
HNF-5177, Rev. 0

Figure 5

Sludge Settling - $\mathrm{Fe}(\mathrm{OH}) 3$ Slurry

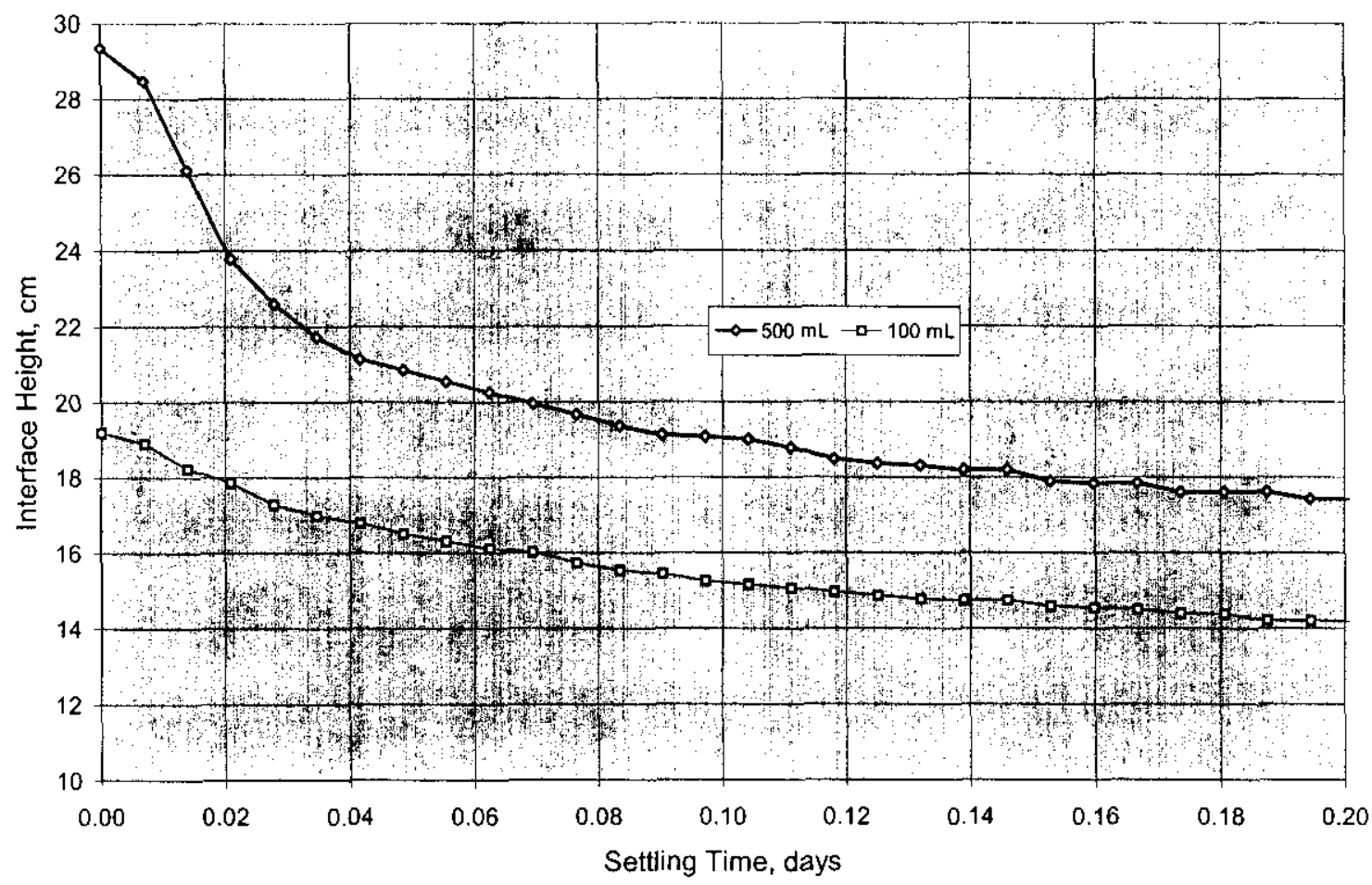


HNF-5177, Rev. 0

Figure 6

Sludge Settling - $\mathrm{Fe}(\mathrm{OH}) 3$ Slurry

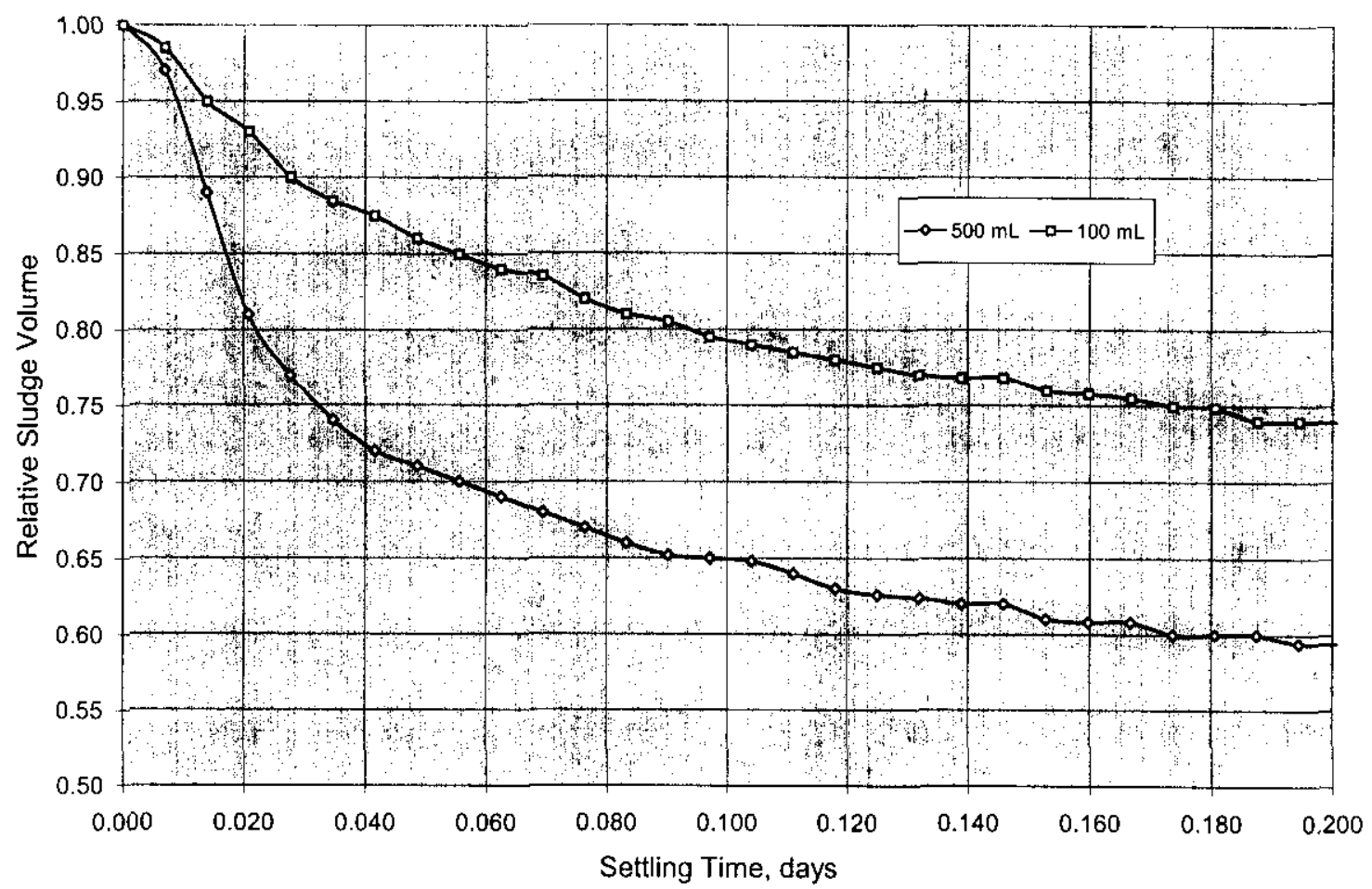

Figure 7

Sludge Settling - NCAW simulant

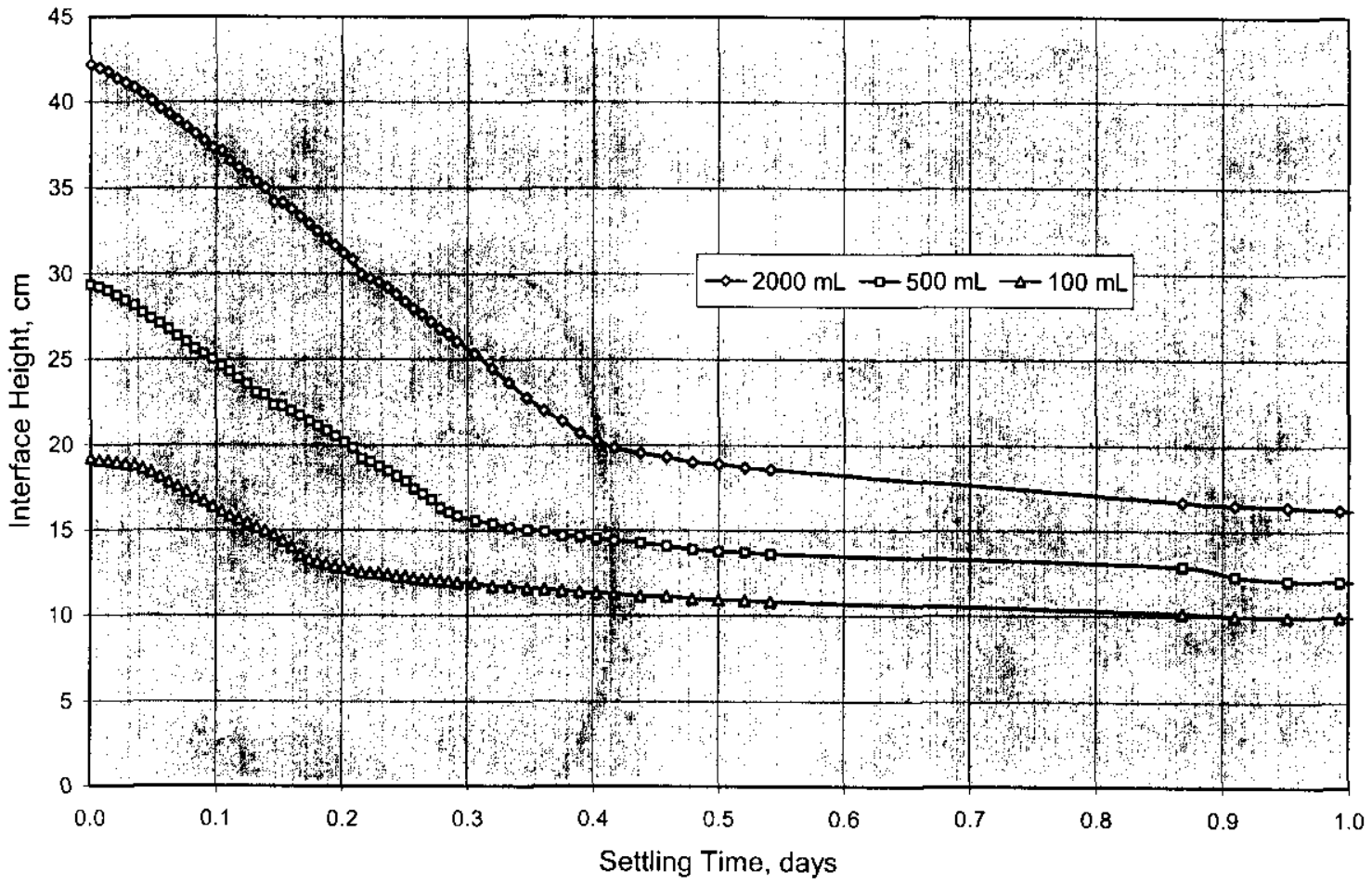


Figure 8

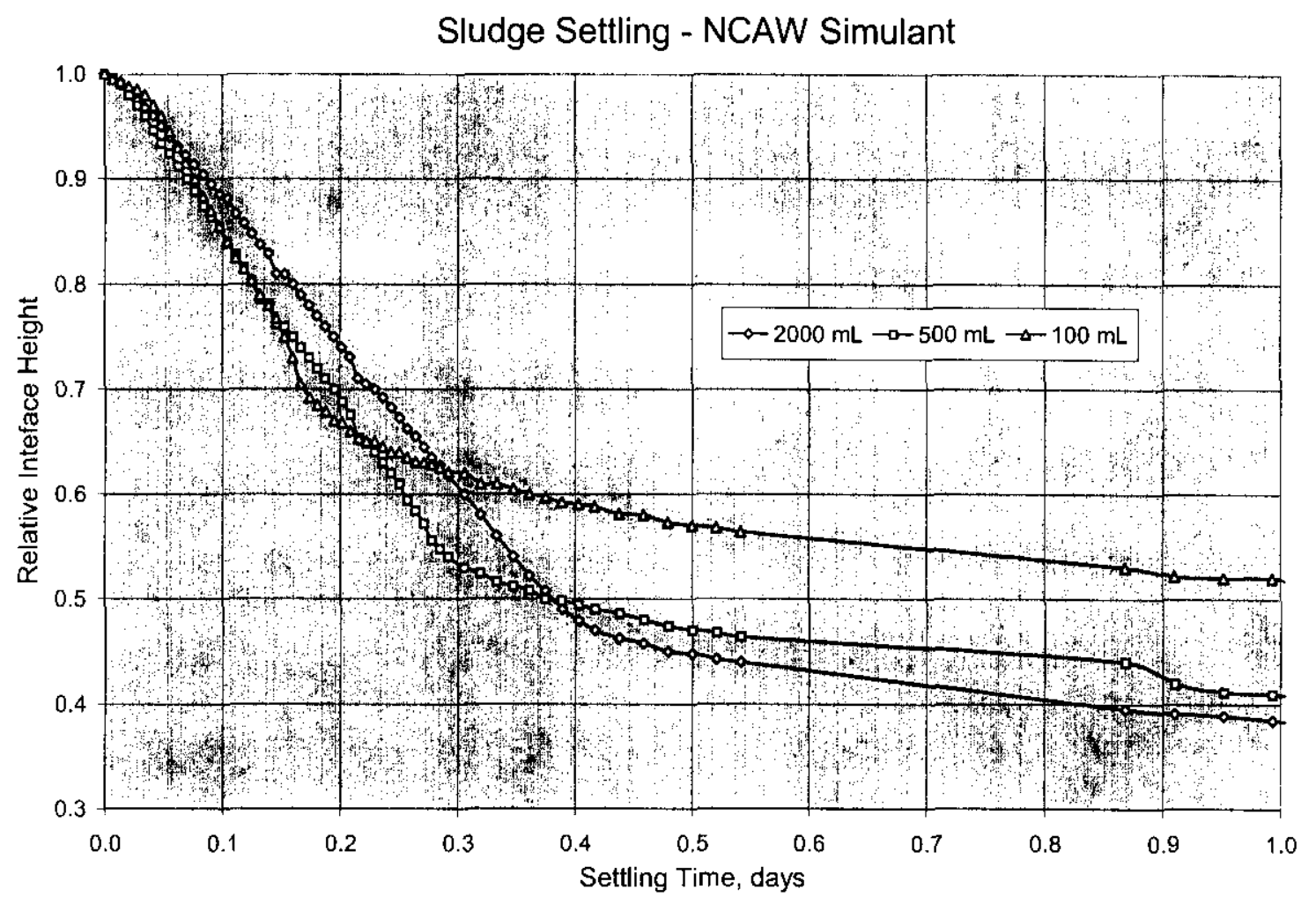

An interesting observation of the $\mathrm{Al}(\mathrm{OH})_{3}-\mathrm{Fe}(\mathrm{OH})_{3}$ test results is that the slopes of the rapid settling period for both the laboratory cylinders and the thirty $\mathrm{ft}$. high column are roughly the same. This is shown in Figures 9,10,11, and 12, in which equations were fitted to the data, and the first derivative (velocity) was calculated and plotted. The maximum velocities are $72,94,74$ and $64 \mathrm{~cm} /$ day, in order of increasing size. These values are all within $20 \%$ of the average maximum velocity of $76 \mathrm{~cm} /$ day. The figures were created using TableCurve 2D, Version 4.0, which can fit data to any of a large number of very complex equations. It can also calculate the first and second derivatives, and plot the equation and derivatives.

This observation leads to the theory that the rapid settling velocity for a slurry in any size test vessel will approximate the rapid settling velocity for a large-scale vessel, such as a waste storage tank. This appears to be true, providing the test vessel is tall enough to allow the development of a rapid settling period. Different slurries will have different minimum heights; for the $\mathrm{Al}(\mathrm{OH})_{3}-\mathrm{Fe}(\mathrm{OH})_{3}$ slurry, a cylinder size larger than $500 \mathrm{~mL}$ is required, while for the NCAW slurry, a $100 \mathrm{~mL}$ cylinder is sufficient. The diameters of the cylinders are as follows: $100 \mathrm{~mL}=2.6 \mathrm{~cm}, 500 \mathrm{~mL}=4.7 \mathrm{~cm}$, and $2 \mathrm{~L}=7.8 \mathrm{~cm}$. Of course, the height needed also depends on how dilute the slurry is - the more concentrated it is, the taller the test cylinder required. Settling experiments carried out in very small tubes or containers are probably not useful, as it is unlikely that the maximum settling velocity would be reached. 
HNF-5177, Rev. 0

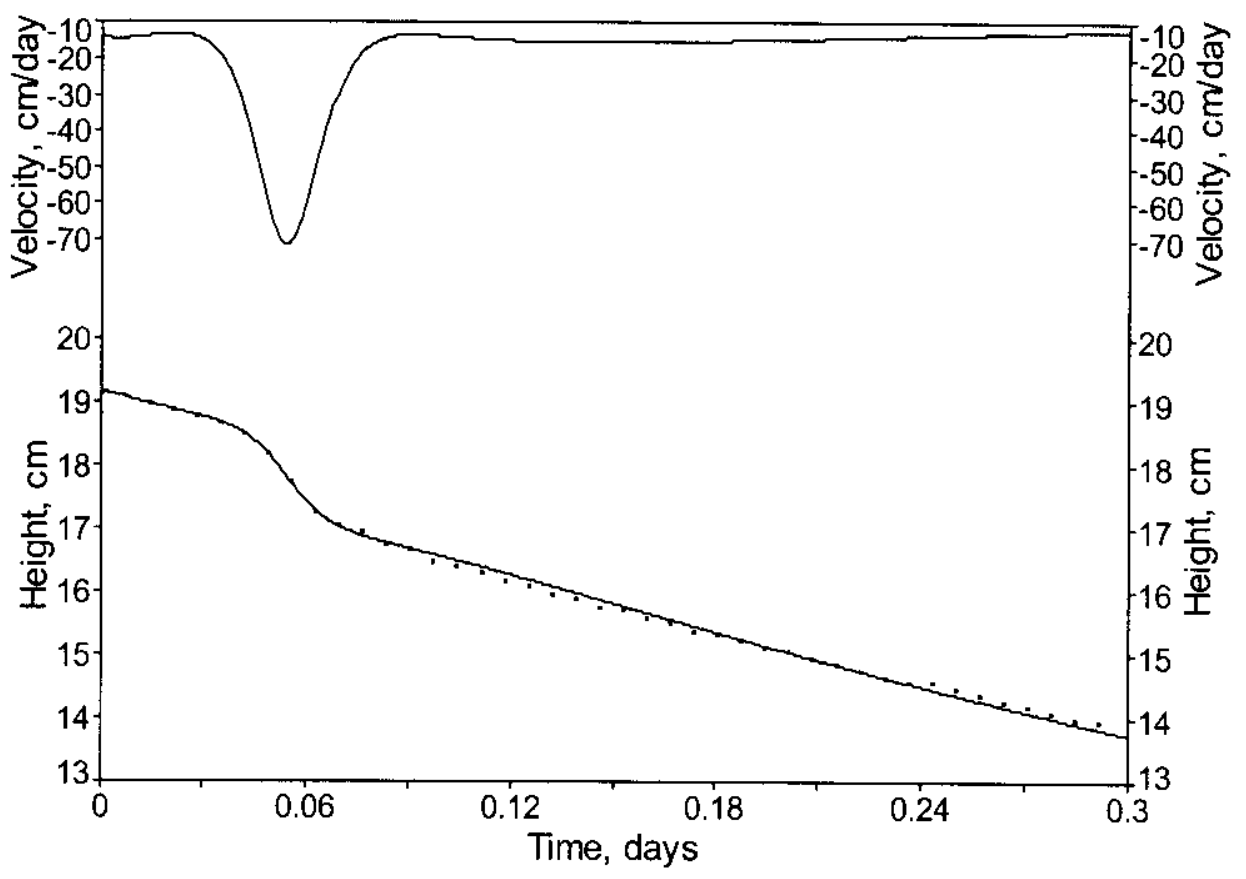

Figure 9 Diluted $\mathrm{Al}(\mathrm{OH}) 3-\mathrm{Fe}(\mathrm{OH}) 3$ Slurry, $100 \mathrm{~mL}$ Cylinder 
HNF-5177, Rev. 0

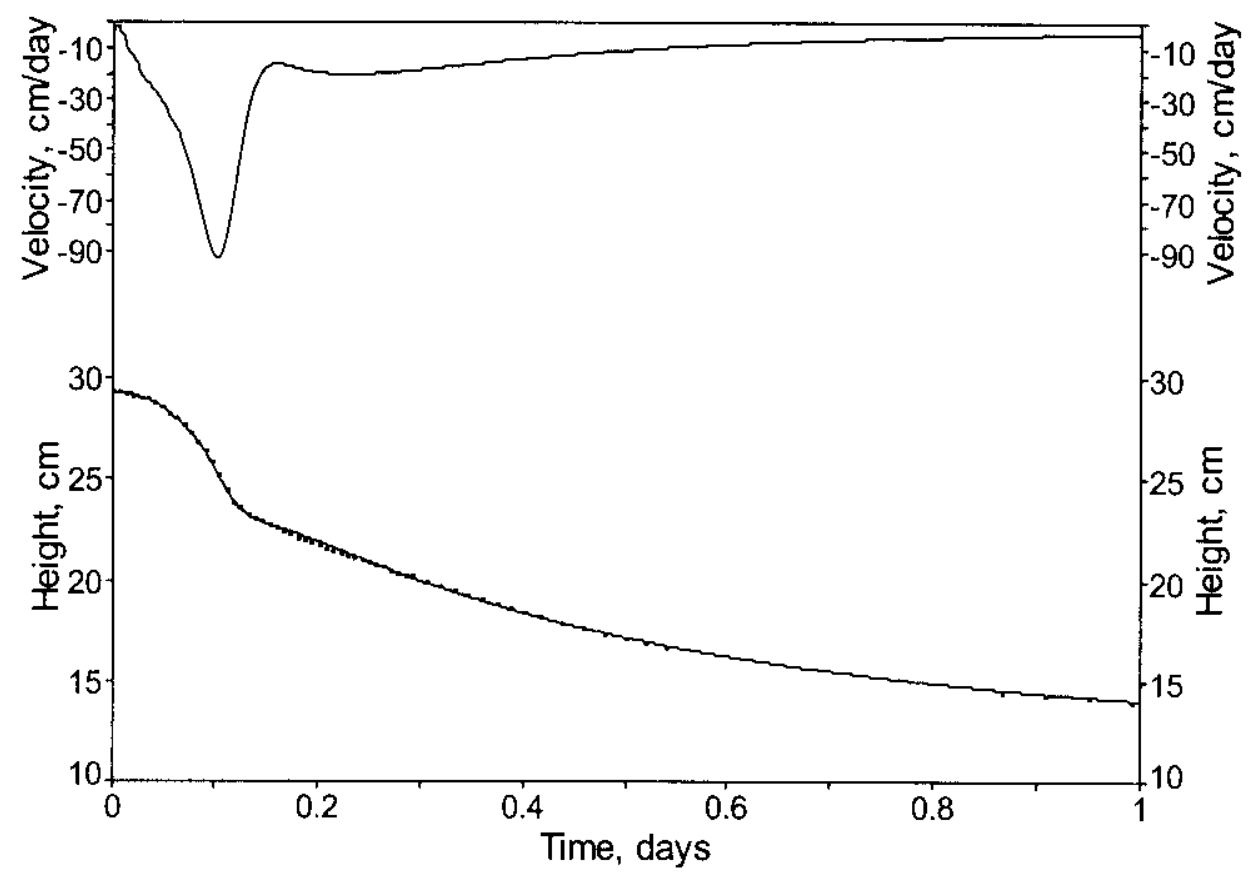

Figure 10 Diluted $\mathrm{Al}(\mathrm{OH}) 3-\mathrm{Fe}(\mathrm{OH}) 3$ Slurry, $500 \mathrm{~mL}$ Cylinder 
HNF-5177, Rev. 0

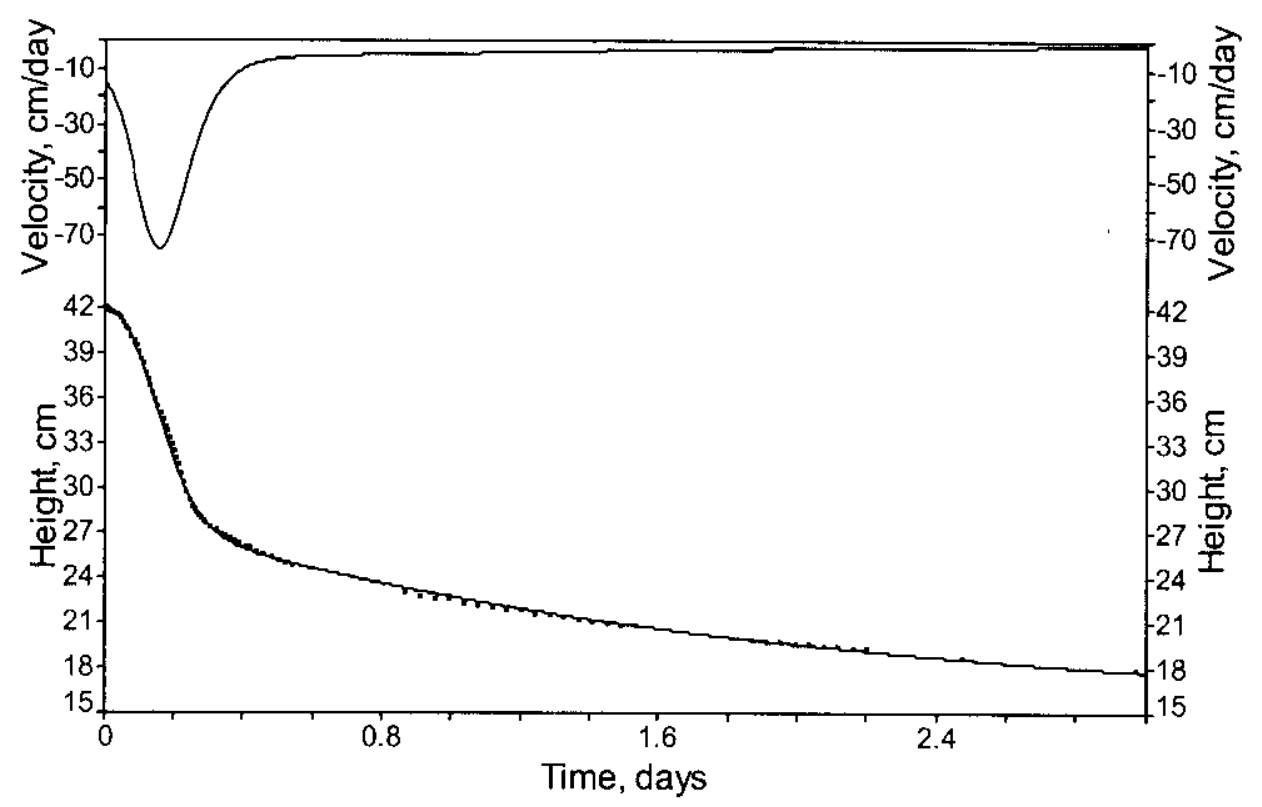

Figure 11 Diluted $\mathrm{Al}(\mathrm{OH}) 3-\mathrm{Fe}(\mathrm{OH}) 3$ Slurry, $2000 \mathrm{~mL}$ Cylinder

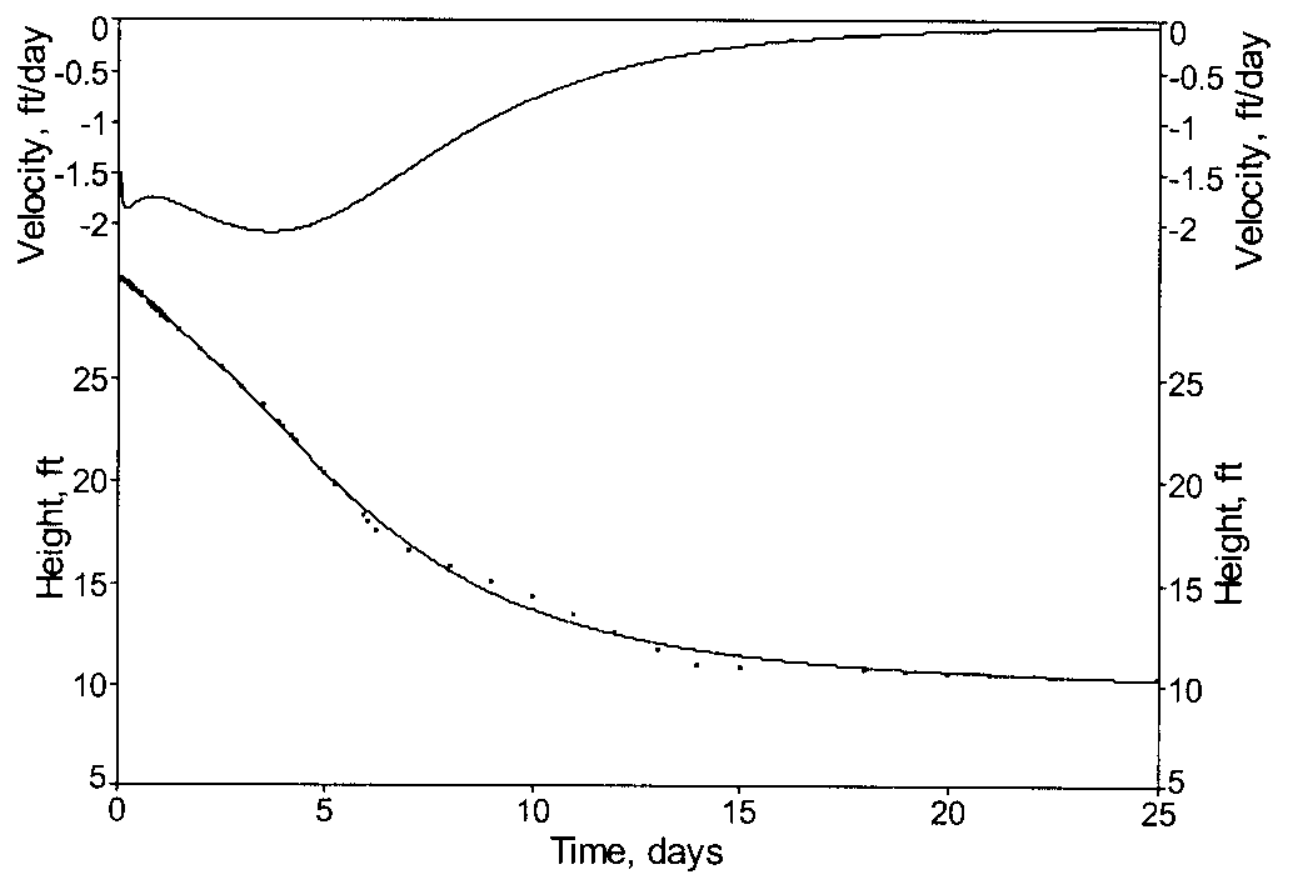


In the early stage of analyzing the results of these settling tests, diameter was thought to be the main vessel parameter that determines the shape of the settling curve (because of particle bridging). However, the settling data obtained with the $\mathrm{Al}(\mathrm{OH})_{3}-\mathrm{Fe}(\mathrm{OH})_{3}$ slurry at four vessel scales indicate that the length of the induction period and as well as the rate of rapid settling are independent of size. Comparison of the rapid settling periods for these tests makes it clear that the difference in duration of the rapid settling period is due to the height available for settling. Thus the settling distance is the parameter that controls the shape of the settling curve. Tests performed in a cylinder that is the diameter of a $100 \mathrm{~mL}$ graduated cylinder, but as tall as a $2 \mathrm{~L}$ graduated cylinder, may well provide the same results as a $2 \mathrm{~L}$ cylinder without requiring as much sample. This makes sense since the primary particles are of the order of nanometers in diameter, and the agglomerates are mostly in the $1-10$ micrometer rage. ${ }^{7}$

As mentioned, the results from the laboratory settling tests with simulants show that the effect of vessel size on settling is a function of sludge composition. The complex NCAW simulated waste slurry did not require as large a cylinder as did the simpler stimulants to obtain useable results. Since the rapid settling period developed more quickly with the NCAW, even the $100 \mathrm{~mL}$ test cylinder appears to be large enough to determine the rapid settling velocity. However, for the NCAW simulant there is a slight but noticeable decrease in the velocity with decreasing cylinder size. This is more pronounced between the 500 and $100 \mathrm{~mL}$ tests than between the $500 \mathrm{~mL}$ and 2 $\mathrm{L}$ tests. This indicates that a small diameter dependence may exist for the NCAW slurry rapid settling velocity that increases as the vessel diameter is decreased. This phenomenon is not apparent with the $\mathrm{Al}(\mathrm{OH})_{3}-\mathrm{Fe}(\mathrm{OH})_{3}$ slurry.

\section{Effect of Sludge Depth on Rate and Extent of Compaction}

In the aluminum production industry, very deep clarifiers are sometimes used to settle out the red mud that is present in the bauxite digestion liquor. ${ }^{8}$ It has been found that higher concentration underflow sludges can be obtained than with conventional clarifiers. One of the goals of the work reported here is to determine the effect that sludge depth has on the sludge concentration and rate of compaction at storage tank scale. This was partially accomplished by conducting one settling test in the $30 \mathrm{ft}$. high column with very concentrated slurry that was near the compaction stage, and one test with a dilution of the same slurry. The slurries used for these test are described in the experimental section. The results are shown in Figures 13 and 14: 
HNF-5177, Rev. 0

Figure 13

Sludge Settling - Undiluted $\mathrm{Al}(\mathrm{OH}) 3-\mathrm{Fe}(\mathrm{OH}) 3$ Slurry

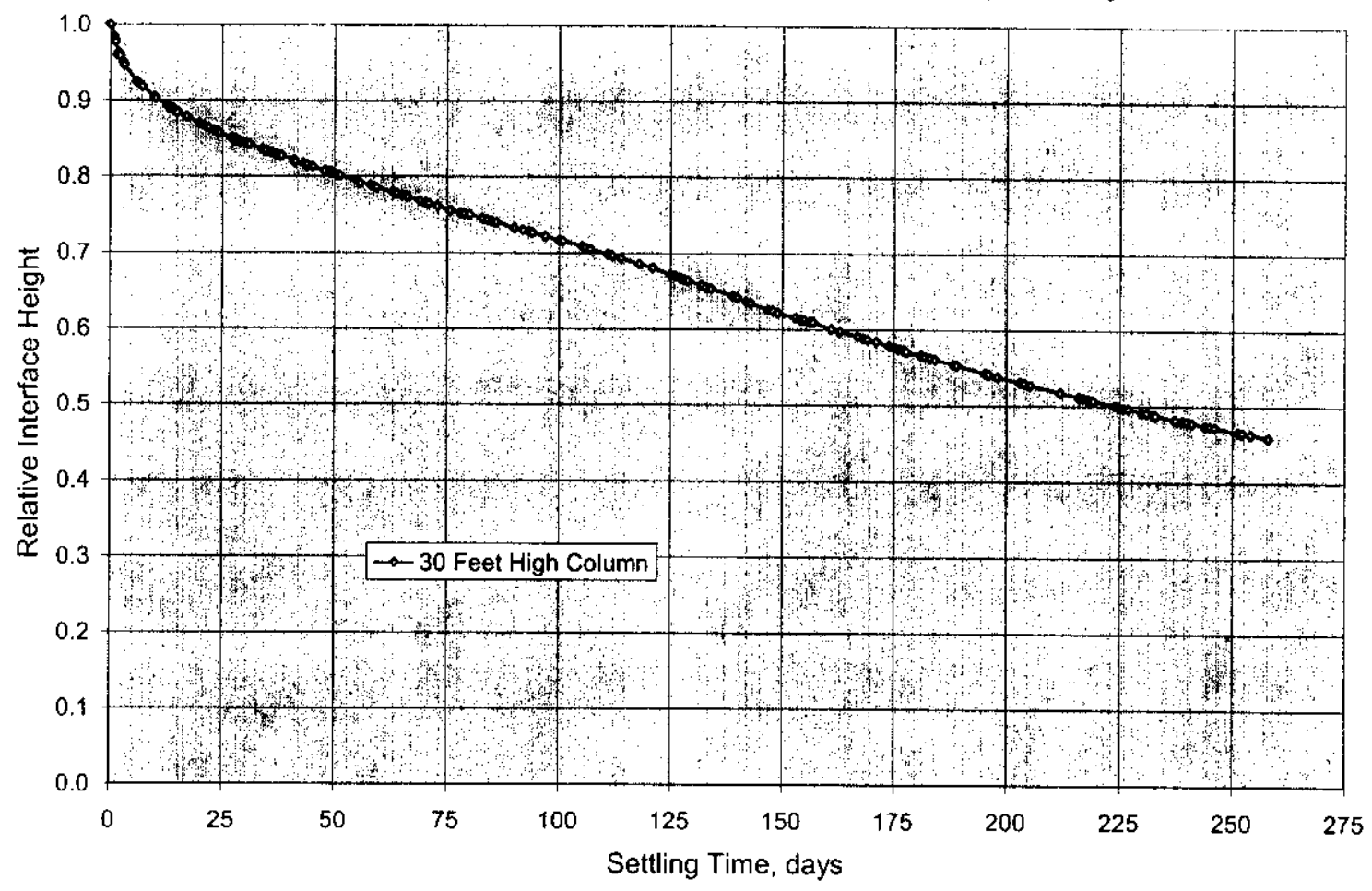

Figure 14

Sludge Settling - Diluted $\mathrm{Al}(\mathrm{OH}) 3-\mathrm{Fe}(\mathrm{OH}) 3$ Slurry

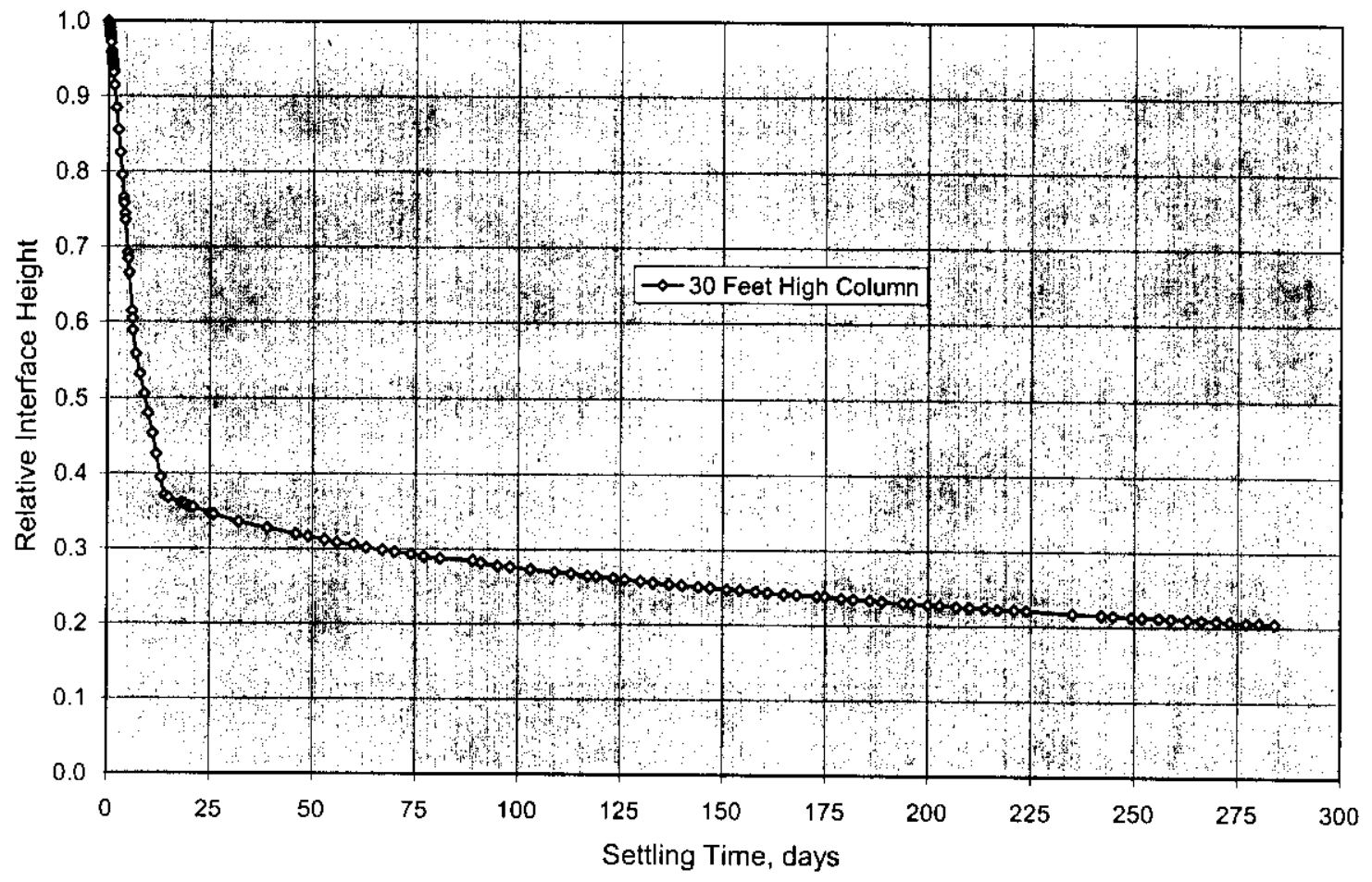


The rate of compaction of the undiluted slurry averaged about $.05 \mathrm{ft} . / \mathrm{day}$, while the rate of the diluted slurry was about $.02 \mathrm{ft}$./day. The average fractional decrease in slurry interface height relative to the final (centrifuged) height was about the same at .3\%/day. However, the deep (undiluted) sludge is predicted to ultimately compact $64 \%$, while the diluted is predicted to compact only $51 \%$. The start and finish of compaction of the undiluted slurry was estimated to be $86 \%$ and $46 \%$ of $30 \mathrm{ft}$. ( 26 and $14 \mathrm{ft}$.), and the same for the diluted to be at $37 \%$ and $21 \%$ of $30 \mathrm{ft}$. (11 and $6.3 \mathrm{ft}$.). The ultimate interface heights, predicted from the centrifuged slurry results as shown in Table 1, are 31\% (9.3 ft.) and 18\% (5.4 ft.), respectively.

The results indicate that the length of time to get to a certain fraction of compaction is about the same for either slurry concentration. However, there is a significant difference in both the compaction rate and extent of compaction that can be achieved for any given length of time. The clarifiers used in aluminum ore processing typically have sludge depths on order of 50 feet; twice that of the deep bed compaction test discussed here. The results of the compaction tests reported here support this industrial practice.

The small-scale laboratory data demonstrate further the effect of sludge depth on the rate and extent of compaction. When the laboratory scale data are compared with the $30 \mathrm{-ft}$. column data, major differences in sludge compaction rate and extent of compaction are seen. This is shown in the normalized height graphs (Figure 15) and dimensionless graphs (Figure 16 and 17) of the data for the diluted $\mathrm{Al}(\mathrm{OH})_{3}-\mathrm{Fe}(\mathrm{OH})_{3}$ slurry. The dimensionless variables are as defined at the end of the Modeling section - with the time offset. The rapid settling part of the dimensional settling curves for every test approximately falls at the same location on the dimensionless curve, but the points from the transition and compaction periods deviate markedy from one to another.

The trends in these dimensionless curves indicate that the rate of compaction is not proportional to the rapid settling rate, and that the ultimate settling height may be a function of vessel size. At the end of the tests (285 days), the normalized interface heights were as follows: $100 \mathrm{~mL}$ cylinder- $.32,500 \mathrm{~mL}$ cylinder - $.28,2 \mathrm{~L}$ cylinder $-.27,30 \mathrm{ft}$. column - .21 . The value when the slurry was centrifuged at the lowest speed was .18. As shown in Figure 14, at the end of the 30 $\mathrm{ft}$. test the sludge had almost reached the centrifudged sludge volume fraction. The sludge volume fractions at the end of the laboratory scale tests were much higher. It is not known whether the laboratory slurries would have compacted to $18 \%$ of the initial volumn if given enough time. However, if the trend found in the $30 \mathrm{ft}$. column tests can be extrapolated to small sizes, they would not.

The conclusion reached from this work is that the sludge depth has a very significant effect on the rate and extent of compaction. Therefore, tests conducted in small (laboratory) size vessels can be used to determine the rapid settling velocity of larger scale sytems, but will not be accurate for determining sludge compaction characteristics of such. 
HNF-5177, Rev. 0

Figure 15

Sludge Settling - Diluted $\mathrm{Al}(\mathrm{OH}) 3-\mathrm{Fe}(\mathrm{OH}) 3$ Slurry

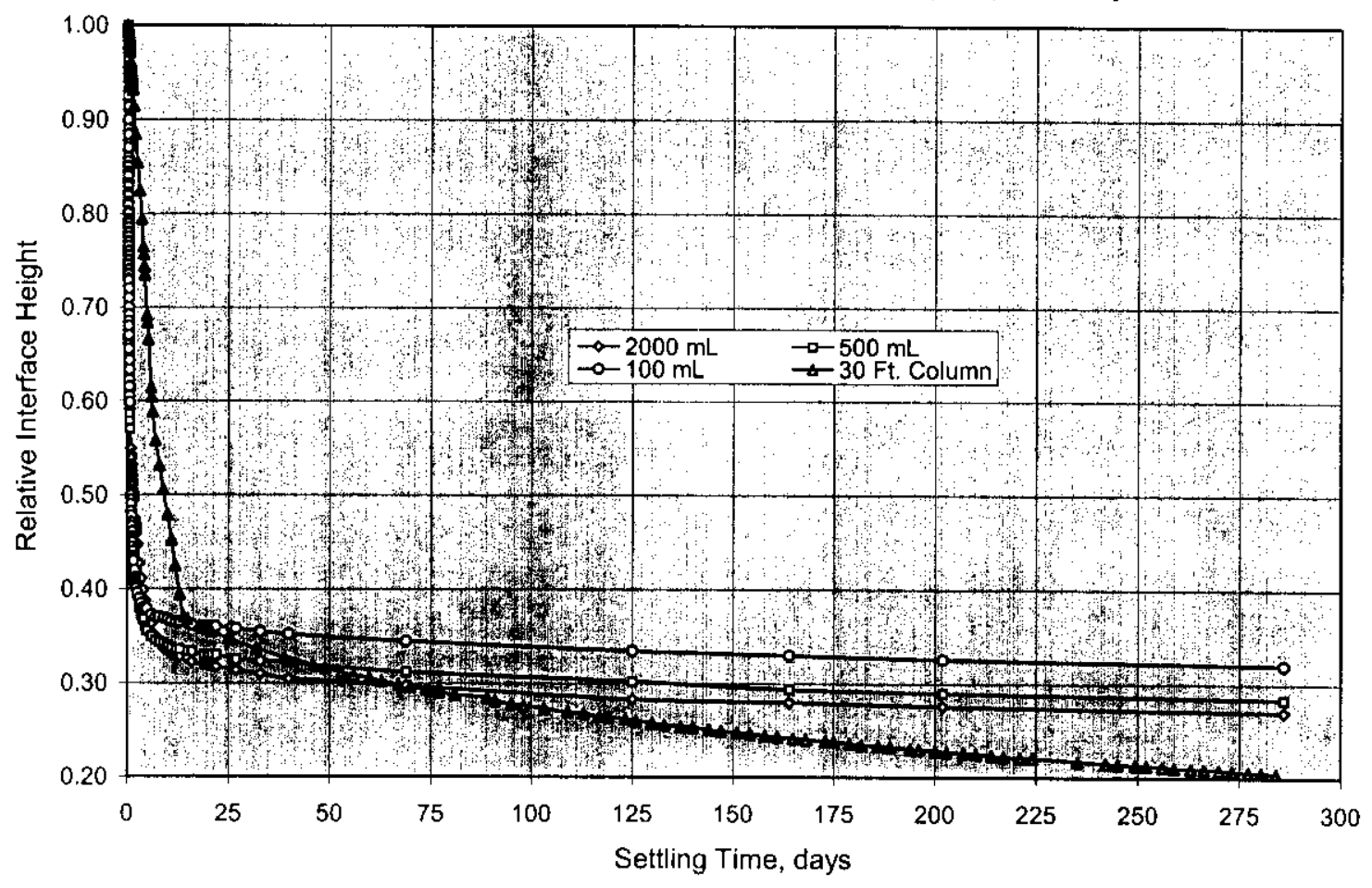


HNF-5177, Rev. 0

\section{Figure 16}

\section{Dimensionless Settling Curve - Diluted $\mathrm{Al}(\mathrm{OH}) 3-\mathrm{Fe}(\mathrm{OH}) 3$ Slurry}

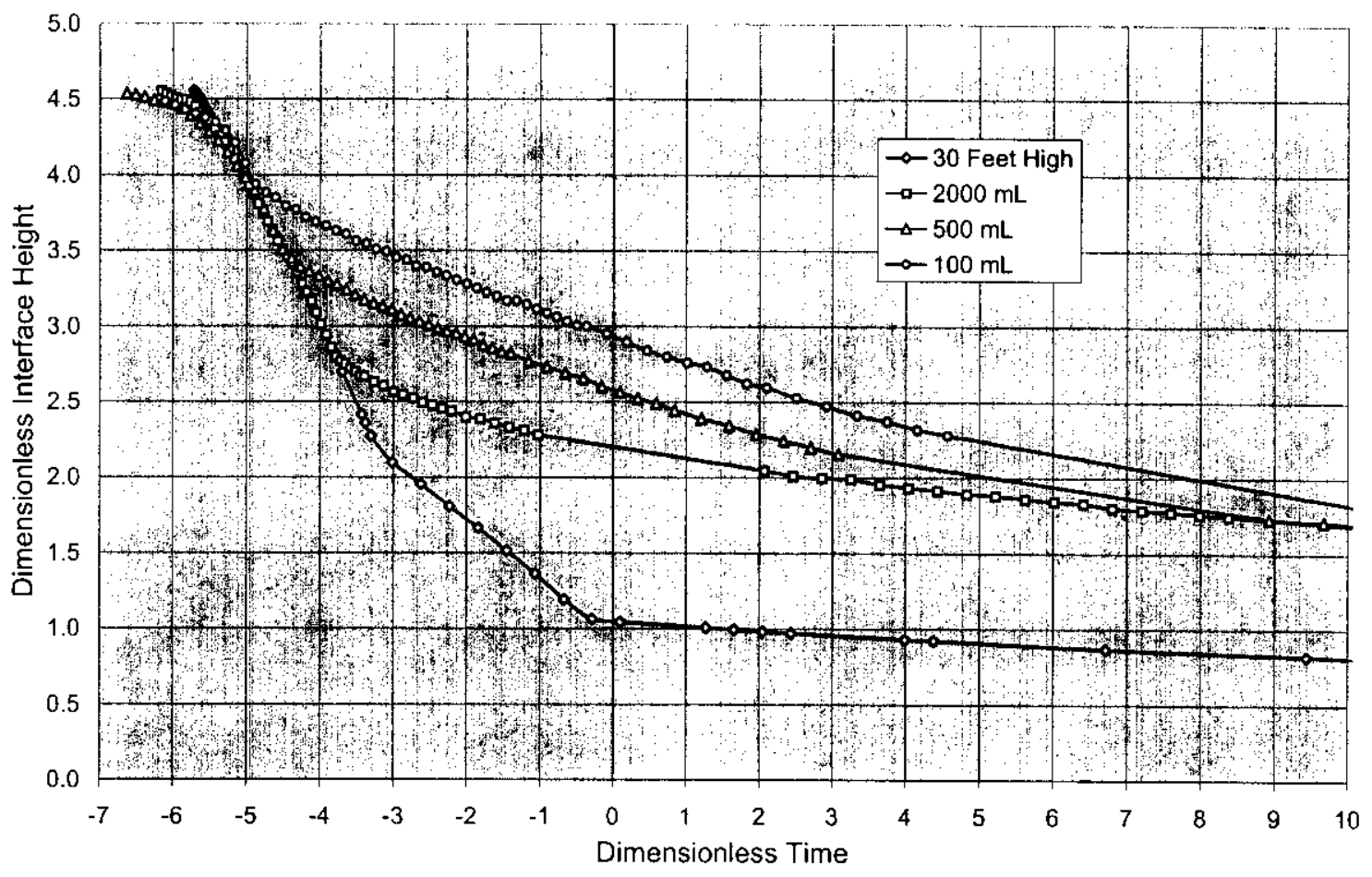


Figure 17

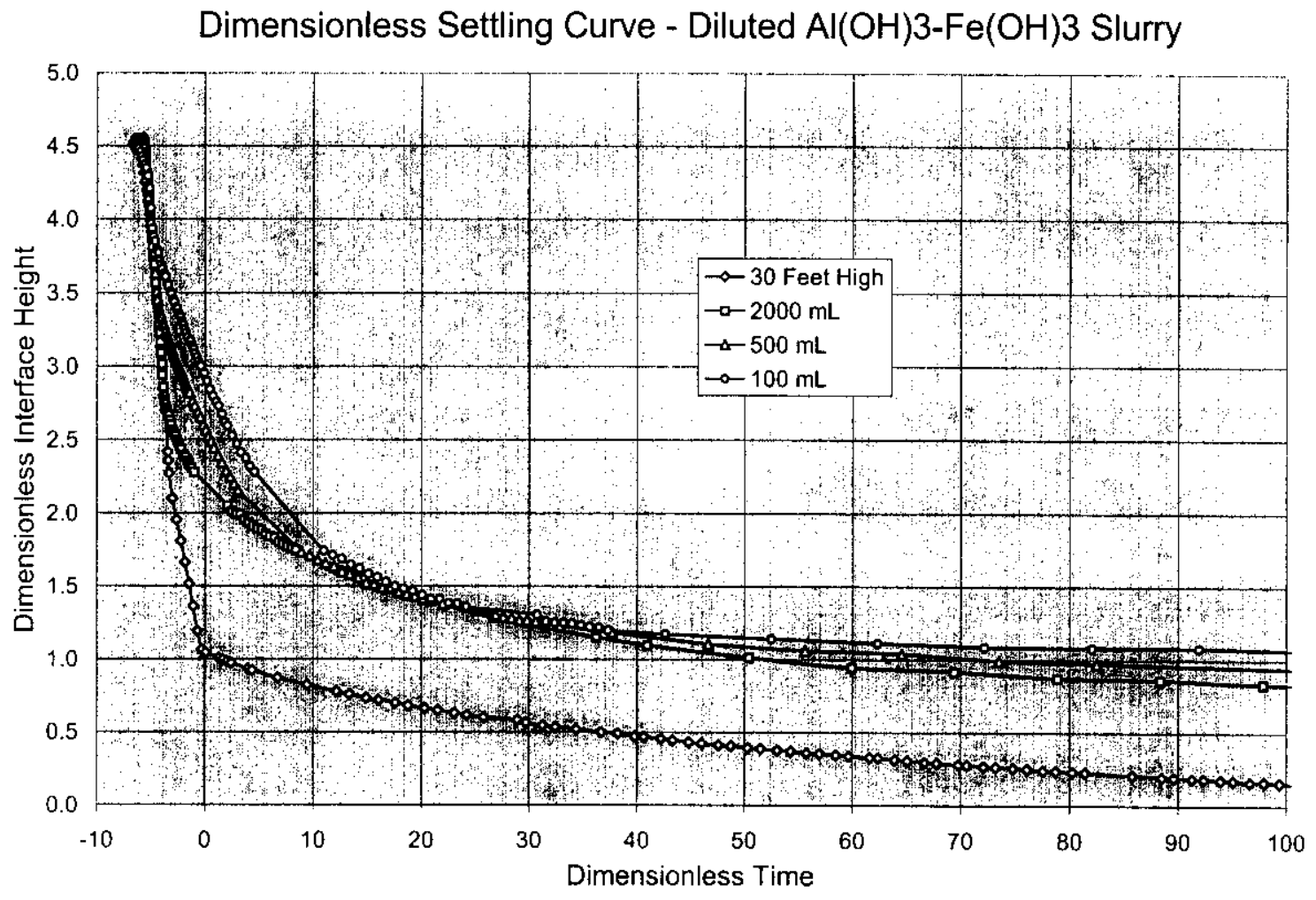

\section{Particle Concentration at the Bottom versus the Slurry Layer Average}

One goal of this work was to determine if the insoluble solids concentration in the bottom of a settling or thickening vessel will increase faster than the average concentration for the slurry layer. This required some way of measuring the concentration at the bottom of the column $30-\mathrm{ft}$. high columns. Several methods were investigated, including electromagnetic, sonic and gamma energy attenuation. It was found that only nuclear energy could penetrate a metal precipitate sludge in a one-ft. diameter column or pipe, and so the gamma energy method was chosen.

An Ohmart Nuclear Density Gage (Model D-3400 SH-F1) was selected and installed so that the beam crossed horizontally about six inches from the bottom of the sludge layer. A picture of the gage at the bottom of the column (with the source removed) is shown on the next page. The attenuation of the $20 \mathrm{mCi}^{137} \mathrm{Cs}$ beam is directly proportional to the mass per volume density of the sludge. This arrangement allowed the measurement of the relative sludge density at the bottom of the column as the sludge settled. To compare the relative density at the bottom of the column with the average of the sludge layer, the relative average sludge layer insoluble solids volumetric concentration was plotted against the density gage readings. The relative average sludge layer concentration was calculated by dividing the initial slurry height by the interface height. 
HNF-5177, Rev. 0

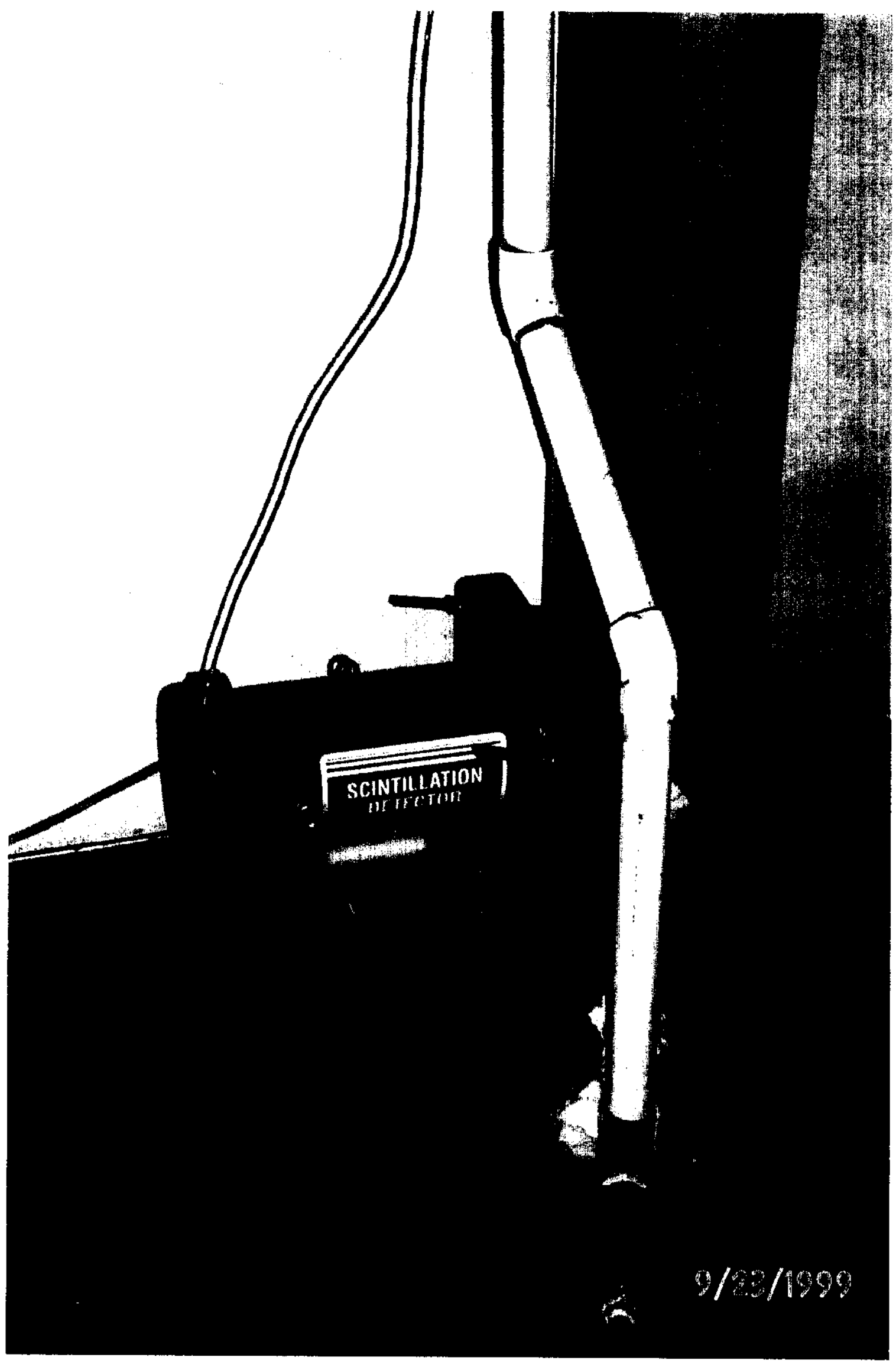


Shown in Figure 18 is a graph from the results of the tests with the undiluted $\mathrm{Al}(\mathrm{OH}) 3-\mathrm{Fe}(\mathrm{OH}) 3$ slurry. Notice that the slope is slightly higher before about the $114^{\text {th }}$ day (equivalent to 21 feet) of the test compared to after. Also, the slope decreased slightly with time before the $114^{\text {th }}$ day, while after this time, the change in gage readings appears proportional to the change in average sludge concentration. This indicates that for about the first 100 days, the sludge concentration at the bottom increased slightly faster than the average, but after 100 days, there is not much difference. In general, however, the sludge concentration appears to be pretty uniform throughout the sludge layer during the compaction stage.

Figure 18

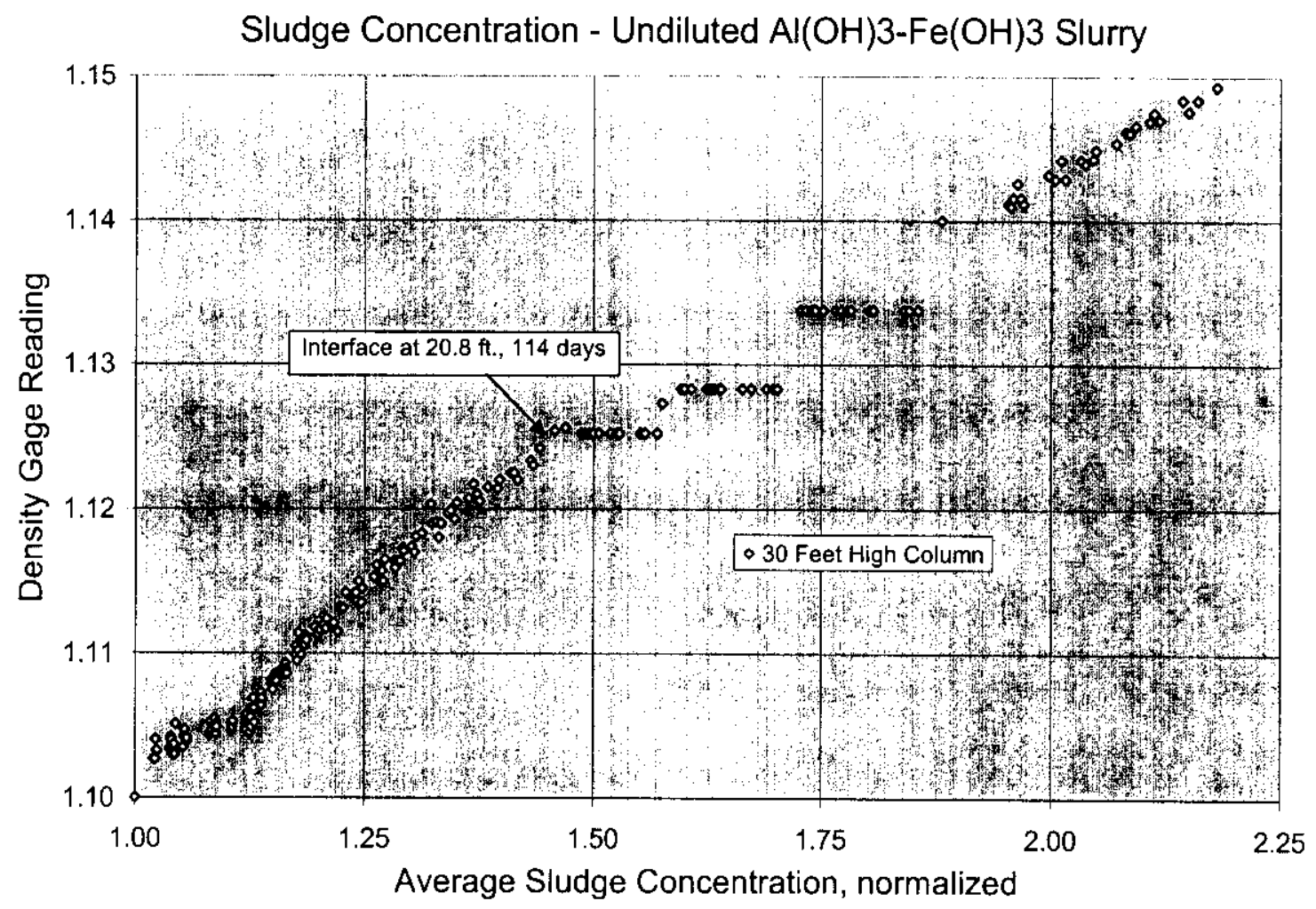

A much different result was found for the settling of the diluted $\mathrm{Al}(\mathrm{OH}) 3-\mathrm{Fe}(\mathrm{OH}) 3$ slurry, during which there was a substantial period of rapid settling. Shown in Figure 19 is the concentration graph for this case. Notice that the concentration rises rapidly as a settled sludge initially builds up on the bottom of the column while the upper layer is still in the rapid settling phase. Then at after about 2.5 days, the gage readings are proportional to the average sludge concentration, indicating that the settled sludge part of the layer had risen above the level of the gage. From that point, the gage reading and the average concentration rose proportionally until 14 days after the start of the test. At this time, gage readings started rising more rapidly than the average layer concentration until about 89 days, when the gage and average rate of increase became proportional again, and with about the same constant of proportionality as between 2.5 and 14 days. 
Figure 19

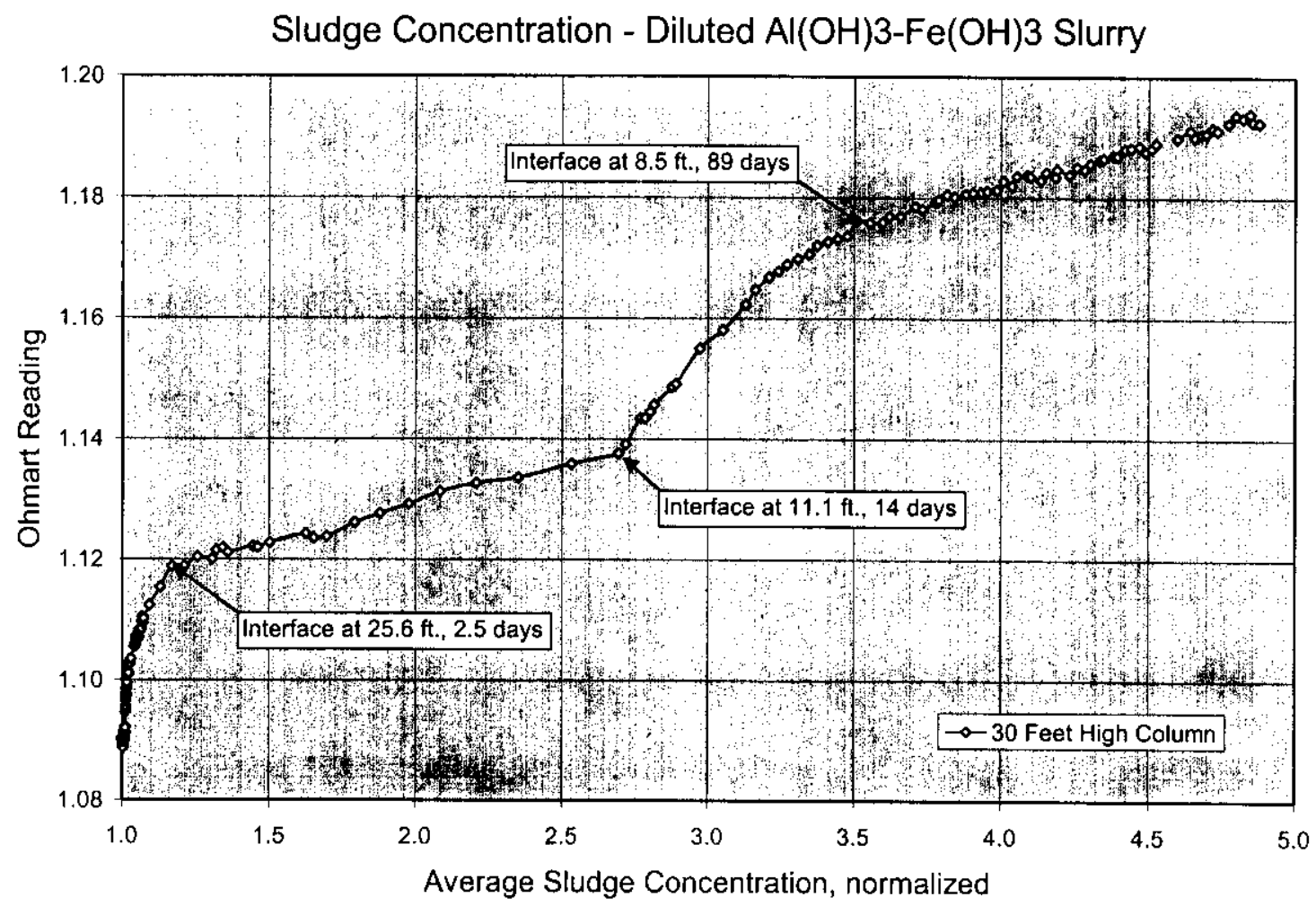

Amazingly enough, these results are very consistent. If the settling curve for the diluted $\mathrm{Al}(\mathrm{OH}) 3-\mathrm{Fe}(\mathrm{OH}) 3$ slurry (Figure 20$)$ is examined, at exactly 14 days the slope of the curve makes an abrupt change from a more rapid or hindered settling regime to a compaction regime. This data confirms that when the slurry first start settling, insoluble solids began compacting on the bottom of the column, forming an interface of sorts between a compacting sludge and the rapidly settling slurry. This interface moved up the column until it reached the top of the slurry layer, or the slurry-liquid interface. At this point, the compacting sludge interface became the sludge-liquid interface, and the entire insoluble solids layer was in the compaction stage. Some slurries may have more of a tendency to do this than others, but it was very pronounced with this slurry. This interface within the slurry layer could not be visually detected with normal room lighting, although it might have been detectable with a strong light source. 
Figure 20

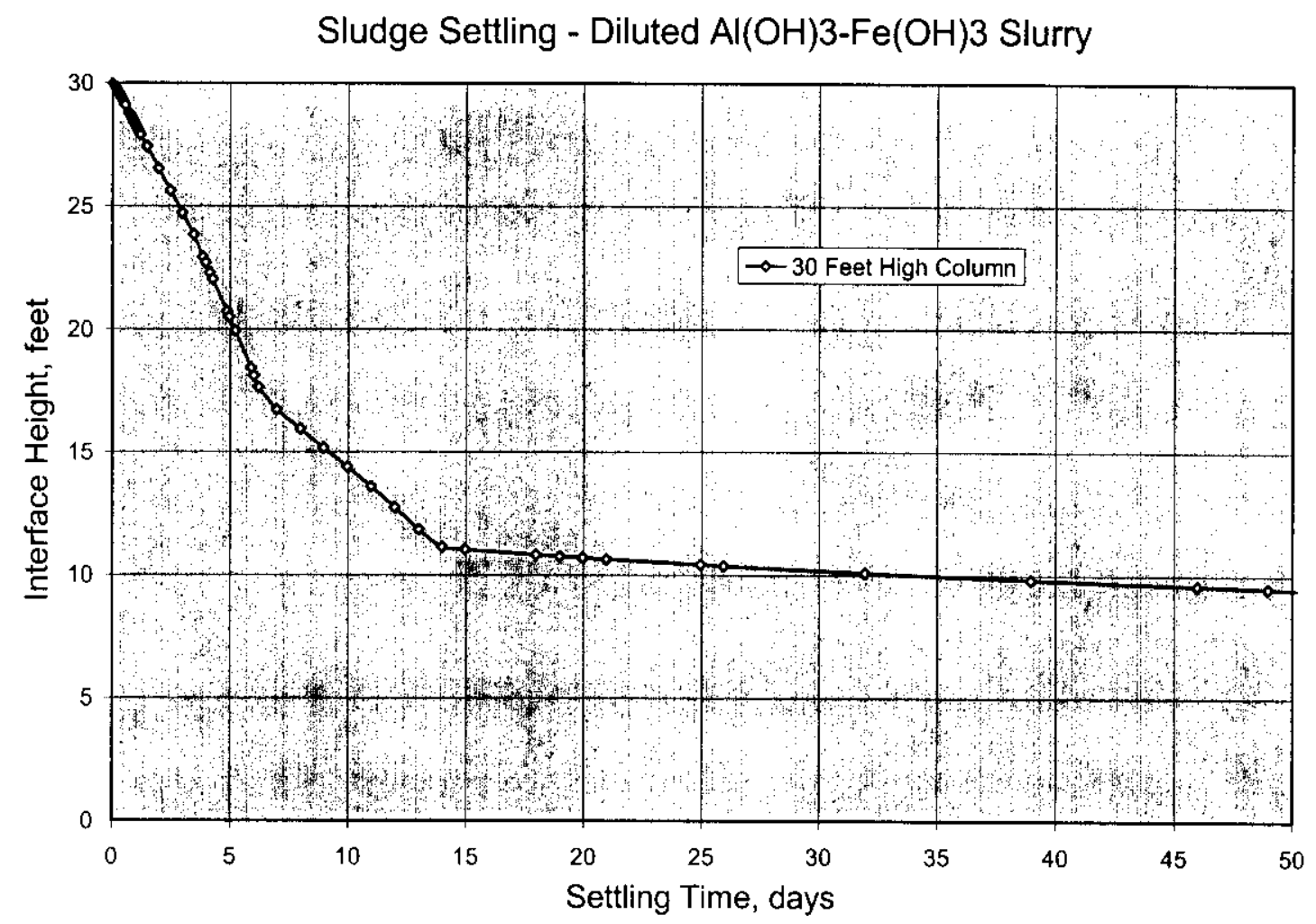

An interesting observation about the curve in Figure 20 is that there are two distinct linear rapidrate settling periods. The first extended from 0-6 days, and the second at a slower rate from 6-14 days. No physical characteristic of the column could be identified as the cause, and no other explanation was apparent. In order to confirm that this was a phenomenon of the slurry and system, and not a unique occurrence, the first two weeks of the settling test was repeated, following exactly the same procedure. The results were virtually identical. In may be more than a coincidence that the slurry is made up of two insoluble metal precipitates $-\mathrm{Al}(\mathrm{OH})_{3}$ and $\mathrm{Fe}(\mathrm{OH})_{3}$ - but it is not clear how this would cause the existence of two rapid settling periods with different rates.

\section{Comparison of Settling Characteristics of Different Wastes}

The settling data from many of the experiments conducted over the last several years at Hanford were analyzed and plotted using TableCurve 2D. Graphs of the results with simulated waste experiments are in Appendix A, with real tank waste miniplant experiments in Appendix B, and with small scale laboratory experiments in Appendix $C$. The maximum settling velocities were determined from the calculated and plotted first derivative of the fitted settling curves. A summary of the results is shown in Table 2. 
HNF-5177, Rev. 0

Table 2

Maximum Settling Velocities of Real and Simulated Wastes

\begin{tabular}{|c|c|c|c|c|}
\hline Waste or Slurry & Slurry Volume & Identification & $\begin{array}{l}\text { Max. Velocity } \\
(\mathrm{cm} / \mathrm{hr})\end{array}$ & Reference \\
\hline $\mathrm{Al}(\mathrm{OH})_{3}-\mathrm{Fe}(\mathrm{OH})_{3}$ & $1 \mathrm{~L}$ & Diluted & 3.0 & This Report \\
\hline$"$ & $.5 \mathrm{~L}$ & (This Study) & 3.9 & \\
\hline " & $2 \mathrm{~L}$ & " & 3.1 & \\
\hline$"$ & $464 \mathrm{~L}$ & “ & 2.7 & \\
\hline " & $.1 \mathrm{~L}$ & Undiluted & 4.2 & This Report \\
\hline " & $.5 \mathrm{~L}$ & (This Study) & 6.3 & \\
\hline " & $464 \mathrm{~L}$ & " & 1.1 & \\
\hline $\mathrm{Fe}(\mathrm{OH})_{3}$ & $.1 \mathrm{~L}$ & This Study & 3.9 & This Report \\
\hline " & $.5 \mathrm{~L}$ & " & 16.7 & \\
\hline “ & $464 \mathrm{~L}$ & “ & 54.9 & \\
\hline NCAW Simulant & $.1 \mathrm{~L}$ & This Study & 1.9 & This Report \\
\hline “ & $.5 \mathrm{~L}$ & " & 2.1 & \\
\hline " & $2 \mathrm{~L}$ & “ & 2.5 & \\
\hline " & $1 \mathrm{Gal}$. & Vessel 1, Run 1 & 3.7 & 9 \\
\hline “ & $"$ & Vessel 1, Wash 1 & 1.5 & \\
\hline “ & “ & Vessel 2, Run 1 & 1.5 & \\
\hline " & " & Vessel 2, Wash 1 & 3.1 & \\
\hline C-106 Sludge & $4.8 \mathrm{~L}$ & $1^{\text {st }}$ Leach & 4.6 & 10 \\
\hline$"$ & " & $2^{\text {nd }}$ Leach & 7.6 & \\
\hline$"$ & " & $1^{\text {st }}$ Wash & 4.4 & \\
\hline$"$ & $"$ & $2^{\text {nd }}$ Wash & 50.8 & \\
\hline$"$ & $"$ & $3^{\text {rd }}$ Wash & 210.8 & \\
\hline C-107 Sludge & $1.35 \mathrm{~L}$ & Wash $2,4.5 \%$ Solids, $50 \mathrm{C}$ & 17.8 & 11 \\
\hline$"$ & $2.75 \mathrm{~L}$ & Wash $2,4.5 \%$ Solids, $50 \mathrm{C}$ & 12.2 & \\
\hline$"$ & $2.75 \mathrm{~L}$ & Wash $2,4.5 \%$ Solids, $25 \mathrm{C}$ & 9.1 & \\
\hline$"$ & $1.48 \mathrm{~L}$ & Wash $2,8 \%$ Solids, $50 \mathrm{C}$ & 9.1 & \\
\hline$"$ & $1.38 \mathrm{~L}$ & Wash $3,9 \%$ Solids, $25 \mathrm{C}$ & 5.6 & \\
\hline S-107 Sludge & $3.1 \mathrm{~L}$ & $1^{\text {st }}$ Retrieval Wash & 12.5 & 12 \\
\hline$"$ & $6.2 \mathrm{~L}$ & $2^{\text {nd }}$ Retrieval Wash & 22.4 & \\
\hline$"$ & $3.3 \mathrm{~L}$ & $1^{\text {st }}$ Caustic Leach & 7.2 & \\
\hline 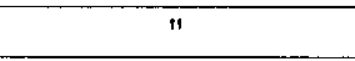 & $2.3 \mathrm{~L}$ & $2^{\text {nd }}$ Caustic Leach & 5.5 & \\
\hline " & $5.1 \mathrm{~L}$ & $2^{\text {nd }}$ Caustic Leach - Part 2 & 8.3 & \\
\hline " & $5.3 \mathrm{~L}$ & $1^{\text {st }}$ Wash & 18.7 & \\
\hline$"$ & $5.3 \mathrm{~L}$ & $1^{\text {st }}$ Wash - Restirred & 18.3 & \\
\hline$"$ & $5.5 \mathrm{~L}$ & $2^{\text {nd }}$ Wash & 18.7 & \\
\hline$"$ & $5.6 \mathrm{~L}$ & $3^{\text {rd }}$ Wash & 13.9 & \\
\hline$"$ & $1.1 \mathrm{~L}$ & Extended Caustic Leach & 7.7 & \\
\hline AZ-101/102 Sludge & Small Lab & $1 \mathrm{M}$ Leach & 7.2 & 13 \\
\hline$"$ & $"$ & $2 \mathrm{M}$ Leach & 5.4 & \\
\hline$"$ & $"$ & $1^{\text {st } 3} \mathrm{M}$ Leach & 5.4 & \\
\hline " & " & $2^{\text {nd }} 3 \mathrm{M}$ Leach & 5.4 & \\
\hline
\end{tabular}


HNF-5177, Rev. 0

\begin{tabular}{|c|c|c|c|c|}
\hline Waste or Slurry & Slurry Volume & Identification & $\begin{array}{l}\text { Max. Velocity } \\
(\mathrm{cm} / \mathrm{hr})\end{array}$ & Reference \\
\hline$"$ & $"$ & $1^{\text {st }}$ Wash & 13.2 & \\
\hline$"$ & $"$ & $2^{\text {nd }}$ Wash & 15.0 & \\
\hline$"$ & $"$ & $3^{\text {rd }}$ Wash & 13.8 & \\
\hline BY-104 Sludge & $"$ & $1^{\text {st }}$ Leach & 7.2 & 14 \\
\hline$"$ & $"$ & $2^{\text {nd }}$ Leach & 22.8 & \\
\hline$"$ & $"$ & $1^{\text {st }}$ Wash & 71.4 & \\
\hline BY-110 Sludge & $"$ & $1^{\text {st }}$ Leach & 1.8 & $“$ \\
\hline “ & $"$ & $1^{\text {st }}$ Wash & 1.2 & \\
\hline C-106 Sludge & $\pi$ & $2^{\text {nd }}$ Leach & 3.1 & 15 \\
\hline$"$ & $"$ & $1^{\text {st }}$ Wash & 22.2 & \\
\hline$"$ & $"$ & $2^{\text {nd }}$ Wash & 12.6 & \\
\hline$"$ & $"$ & $3^{\text {rd }}$ Wash & 34.2 & \\
\hline S-107 Sludge & " & $1^{\text {st }}$ Leach & 1.8 & 16 \\
\hline$"$ & $"$ & $1^{\text {st }}$ Wash & 27 & \\
\hline$"$ & $"$ & $2^{\text {nd }}$ Wash & 19.2 & \\
\hline$"$ & $"$ & $3^{\text {rd }}$ Wash & 16.8 & \\
\hline SX-108 Sludge & $"$ & $1^{\text {st }}$ Leach & 2.2 & “ \\
\hline " & " & $2^{\text {nd }}$ Leach & 2.4 & \\
\hline$"$ & $"$ & $1^{\text {st }}$ Wash & 5.4 & \\
\hline
\end{tabular}

\subsection{CONCLUSIONS}

The following conclusions regarding metal precipitate slurries, such as found in aqueous nuclear fuel processing waste, have been made as a result of the work reported here:

1. When settling, the slurries undergo, to one degree or another, an initial period of flocculation or agglomeration that involves little settling.

2. Following the agglomeration period, slurries that are dilute enough, and in vessels that are deep enough, undergo a period of rapid settling that is more or less linear in velocity and independent of vessel size or geometry, and is characteristic of the slurry.

3. The compaction characteristics of a metal precipitate sludge are dependent on the concentration of insoluble solids and on the size of the vessel - the deeper the sludge, the faster the rate of compaction and the greater the ultimate extend of compaction.

4. The mode of settling for dilute enough slurries is that as the liquid-slurry interface level decreases, the particles on the bottom of the vessel begin building up a sludge layer that eventually meets the liquid-slurry interface. At this point in time, the entire layer is in the sludge compaction regime, and the sludge compacts uniformly with height. 
The settling characteristics of a slurry in a large size vessel can be predicted from laboratory tests by carrying out the following:

(a) Determine the rapid settling velocity of the interface with laboratory tests.

(b) Determine the ultimate or minimum sludge height by centrifuging a sample and finding the ratio of centrifuged sludge height to initial slurry height, then multiplying the ratio times the initial slurry height in the full size vessel.

(c) Calculate the initial slurry dimensionless height from the actual height and ultimate compacted sludge height.

(d) Select the desired final process dimensionless sludge height from the universal settling curve (shown in Figure 21) and find the difference in dimensionless time from initial dimensionless height to final.

(e) Calculate the actual settling time from the dimensionless time difference determined in the previous step using Equation 6.

The above method is not valid if the slurry is so concentrated that it does not progress through a rapid settling period as it settles. In such a case, the slurry is going to compact to the slowcentrifuged volume fraction at a rate dependent on the size of the vessel.

Figure 21

Universal Dimensionless Settling Curve (from $30 \mathrm{ft}$. diluted $\mathrm{Al}(\mathrm{OH}) 3-\mathrm{Fe}(\mathrm{OH}) 3$ siurry test)

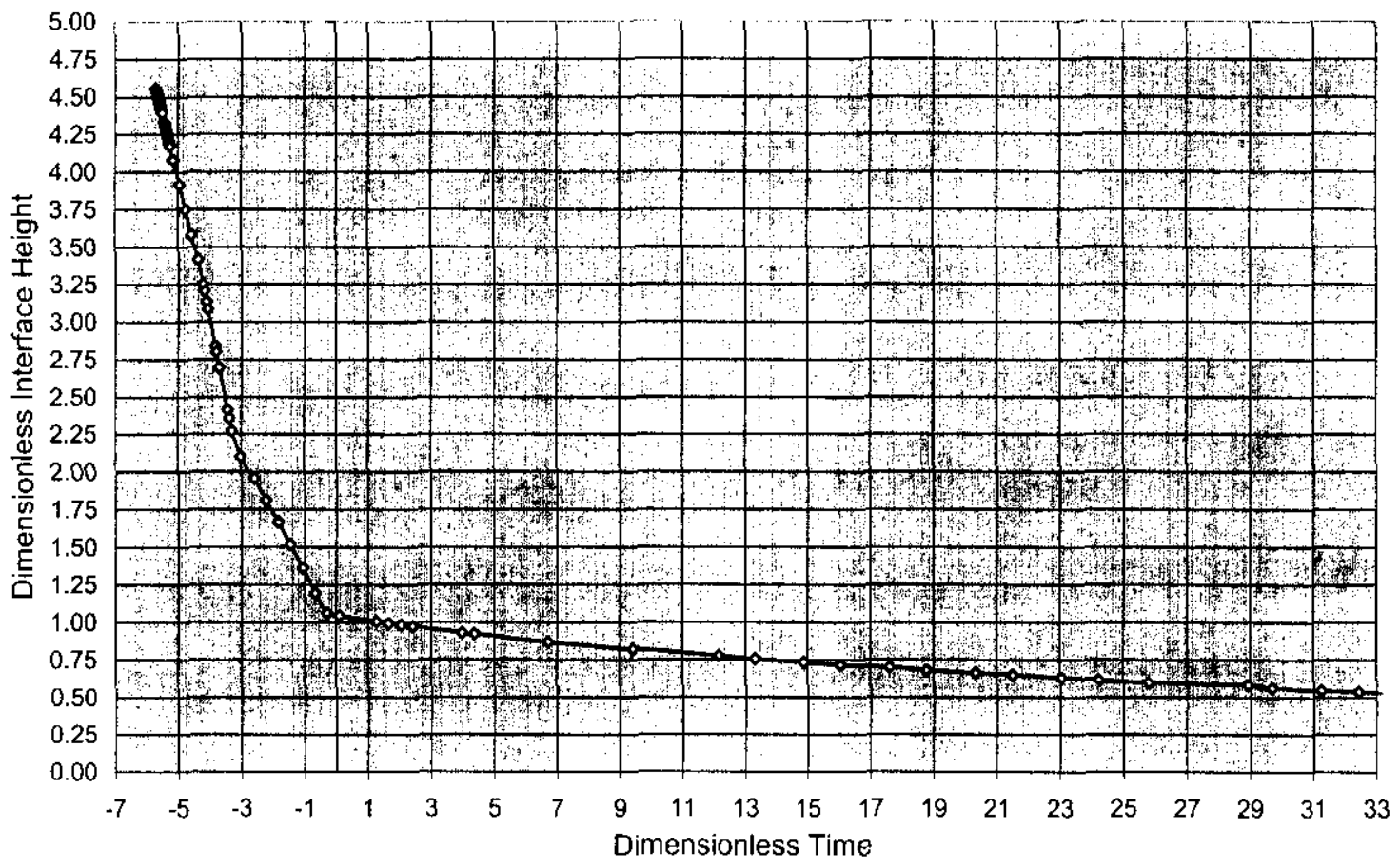




\subsection{ACKNOWLEDGEMENTS}

The contributions of the following individuals is greatly appreciated:

Don Squier of Numatec Hanford Corporation and Ted Hohl of COGEMA Engineering Corp for carrying out the tests in the first $30 \mathrm{ft}$. column in Bldg. 305 and analyzing the slurries.

Dennis Graves, Don Gana, and Jeff Pintler of COGEMA Engineering Corp. for carrying out the tests in the second $30 \mathrm{ft}$. column in Bldg. 306 and analyzing the slurries.

Monika Finnicum, Hong Chang, and QD H of Fluor Daniel Northwest (FDNW) for graphing and analyzing settling data.

Kristen Brooks of the Pacific Northwest National Laboratory for supplying the settling data from the miniplant tests with Tank C-106, C-107, and S-107 wastes.

Marvine Baechler of FDNW for preparing the manuscript for publication. 


\subsection{REFERENCES}

${ }^{1}$ Norton, M.V., and F. Torres-Ayala, "Summary Letter-Laboratory Testing, In-tank Sludge Washing," PNL-10153, Pacific Northwest National Laboratory, Richland, WA, September 1993

${ }^{2}$ Ibid.

${ }^{3}$ Standard Methods for the Examination of Water and Wastewater, $18^{\text {th }}$ Edition, American Public Health Association, Washington, D.C., 1992

${ }^{4}$ Slurry Handling Design of Solid-Liquid Systems, N.P. Brown and N.I. Heywood, Elsevier Science Publishing Co., NY, NY, 1991, pp. 26-28

${ }^{5}$ Li, Yigong, and Ashish J. Mehta, "Assessment of Hindered Settling of Fluid Mudlike Suspensions,” J. of Hydraulic Engineering, February 1998, pp. 176-178

${ }^{6}$ Rector, D. R., and B. C. Bunker, "Sedimentation Models," PNL-10754, Pacific Northwest National Laboratory, Richland, WA, September 1995

${ }^{7}$ Rector, D. R., and B. C. Bunker, "Effect of Colloidal Aggregation on the Sedimentation and Rheological Properties of Tank Waste," PNL-10761, Pacific Northwest National Laboratory, Richland, WA, September 1995

${ }^{8}$ Tiller, F. M., and D. Tarng, "Try Deep Thickeners and Clarifiers," Chem. Eng. Progress, March 1995, pp. 75-80

${ }^{9}$ Reference 1

${ }^{10}$ Brooks, K. P., R. L. Myers, K. G. Rappe, "Bench-Scale Enhanced Sludge Washing and Gravity Settling of Hanford Tank C-106," PNNL-11432, Pacific Northwest National Laboratory, Richland, WA, January 1997

${ }^{11}$ Brooks, K. P., J. R. Phillips, R. L. Myers, K. G. Rappe, D. R. Rector and P. A. Smith, "Sludge Pretreatment Studies Using Hanford Tank C-107," TWRS Low-Level Waste Addback Program, Letter report prepared for Westinghouse Hanford Company by Pacific Northwest Laboratory, Richland, WA, 1996

${ }^{12}$ Brooks, K. P., J. R. Bontha, G. R. Golcar, R. L. Myers, K. G. Rappe, and D. R. Rector, "Bench-Scale Enhanced Sludge Washing and Gravity Settling of Hanford Tank S-107 Sludge," PNNL-12010, Pacific Northwest National Laboratory, Richland, WA, September 1998

${ }^{13}$ Rapko, B. M., and M. J. Wagner, "Caustic Leaching of Composite AZ-101/AZ-102 Hanford Tank Sludge,” PNNL-1 1580, Pacific Northwest National Laboratory, Richland, WA, July 1997 
${ }^{14}$ Lumetta, G. J., B. M. Rapko, M. J. Wagner, J. Liu, Y. L. Chen, "Washing and Caustic Leaching of Hanford Tank Sludges: Results of FY 1996 Studies," PNNL-11278, Rev. 1, Pacific Northwest National Laboratory, Richland, WA, August 1996

${ }^{15}$ Lumetta, G. J., M. J. Wagner, F. V. Hoopes, and R. T. Steele, "Washing and Caustic Leaching of Hanford Tank C-106 Sludge," PNNL-1 1381, Pacific Northwest National Laboratory, Richland, WA, October 1996

${ }^{16}$ Reference 14

Other Related References:

Bhattacharya, I. N., "Settling and filtration characteristics of fine alumina trihydrate slurry," International J. Mineral Processing, 49 (1997), pp. 107-118

Bullough, B. D., "NCAW Solid/Liquid Separation via Sedimentation," SD-WM-TRP-024, Rockwell Hanford Operations, Richland WA, 1987

Davis, G. M., L. E. Butler, and J. H. Koon, "Liquid/Solids Separation Evaluation and Treatment Process Design for a Synthetic Nuclear Sludge," report submitted to Rockwell Hanford Operations, Richland, WA, by Assoc. Water and Air Resources Engineers, Inc., Nashville, TN, April 1979

Galvin, K. P., "Measurement of Particle Velocity During Sediment Consolidation," Chemical Engineering Science, vol. 51, No. 12, 1996, pp. 3241-3246

Kos, P., "Fundamentals of Gravity Thickening," Chem. Eng. Prog., November 1977, pp. 99-105

Ong, S. L., "Effect of measurement error of settling velocity on secondary sedimentation tank design," Water Environment Research, Vol. 64, No. 2, March/April 1992, pp. 104-110

Ozer, A., "Simple Equations to Express Settling Column Data," Technical Note 4749, J. Environ. Eng., Vol. 120, No. 3, May/June 1994

Shirato, M., H. Kato, K. Kobayashi, and H. Sakazaki, "Analysis of Settling of Thick Slurries Due to consolidation," J. Chem. Eng. Japan, vol. 3, No. 1, 1970, pp. 98-104

Tarrer, A. R., D. L. Vives, and D. M. Kennedy, "A Model for Continuous Thickening," Fundamental Aspects of Hydrometallurgical Processes, AIChE Symposium Series, 1978, pp. 6774

Van Siclen, C. DeW., "Analytical description of solid suspension settling," Minerals and Metallurgical Processing, May 1994, pp. 118-120 
HNF-5177, Rev. 0

Blank Page 
HNF-5177, Rev. 0

\section{APPENDIX A}

\section{SIMULATED WASTE SETTLING TESTS}

A-0 
HNF-5177, Rev. 0

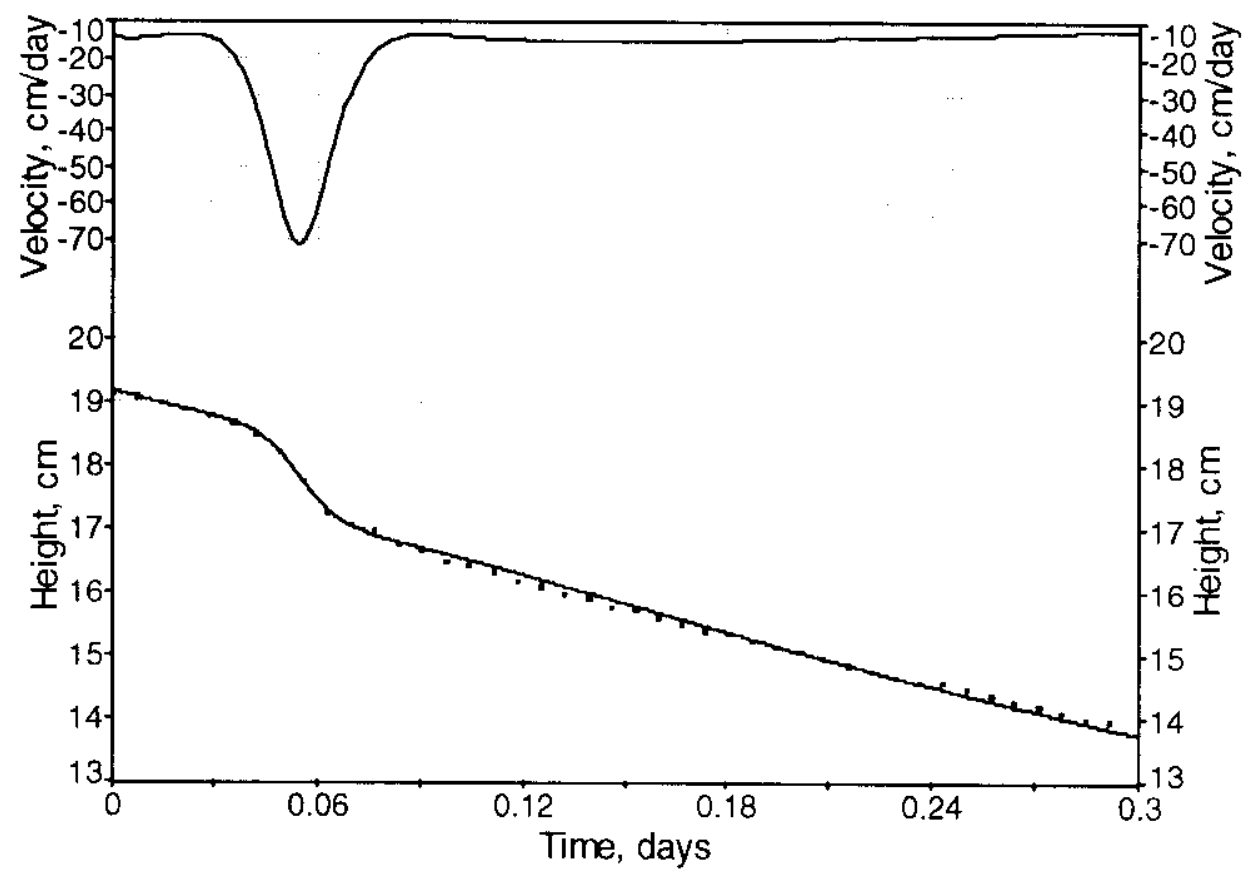

Diluted $\mathrm{Al}(\mathrm{OH})_{3}-\mathrm{Fe}(\mathrm{OH})_{3}$ Slurry $-100 \mathrm{~mL}$

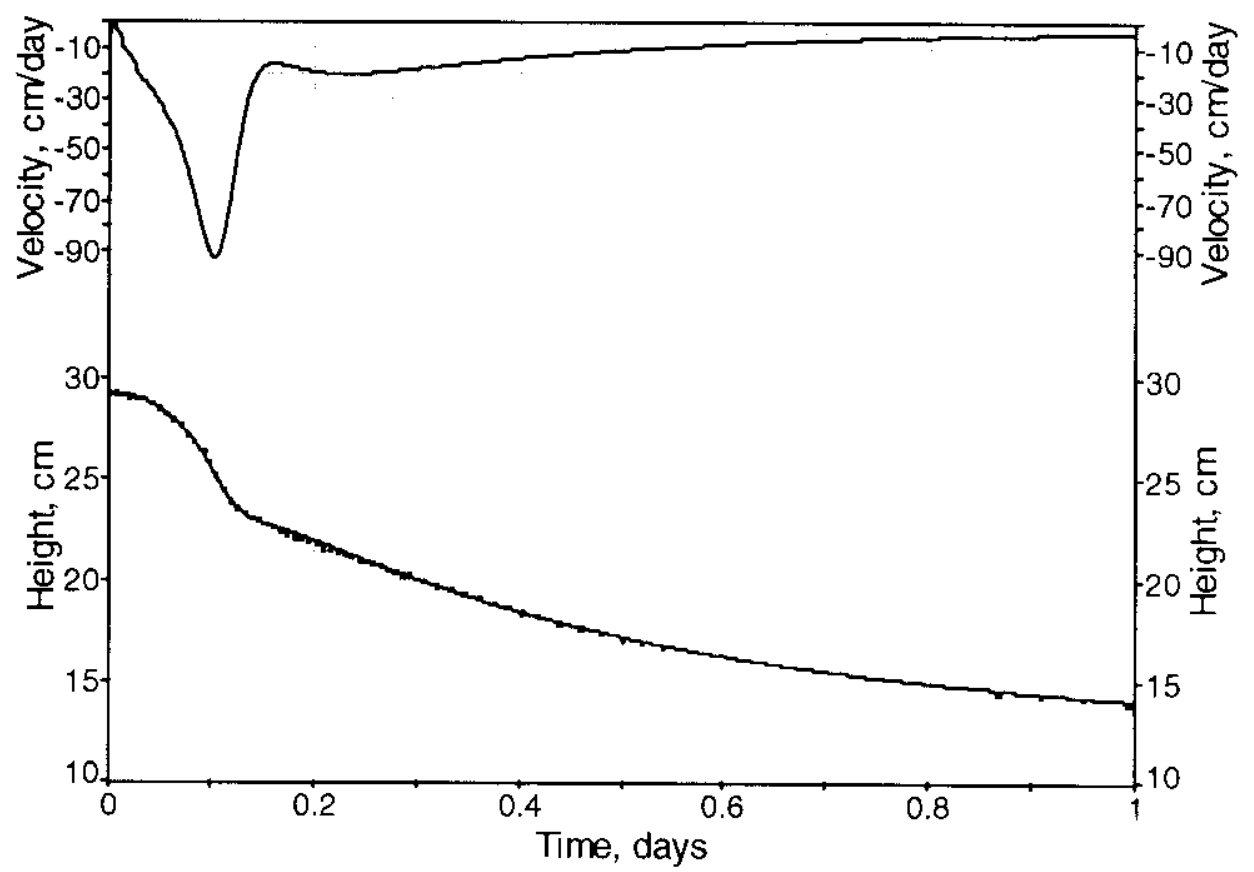

Diluted $\mathrm{Al}(\mathrm{OH})_{3}-\mathrm{Fe}(\mathrm{OH})_{3}$ Slurry $-500 \mathrm{~mL}$

A-1 
HNF-5177, Rev. 0

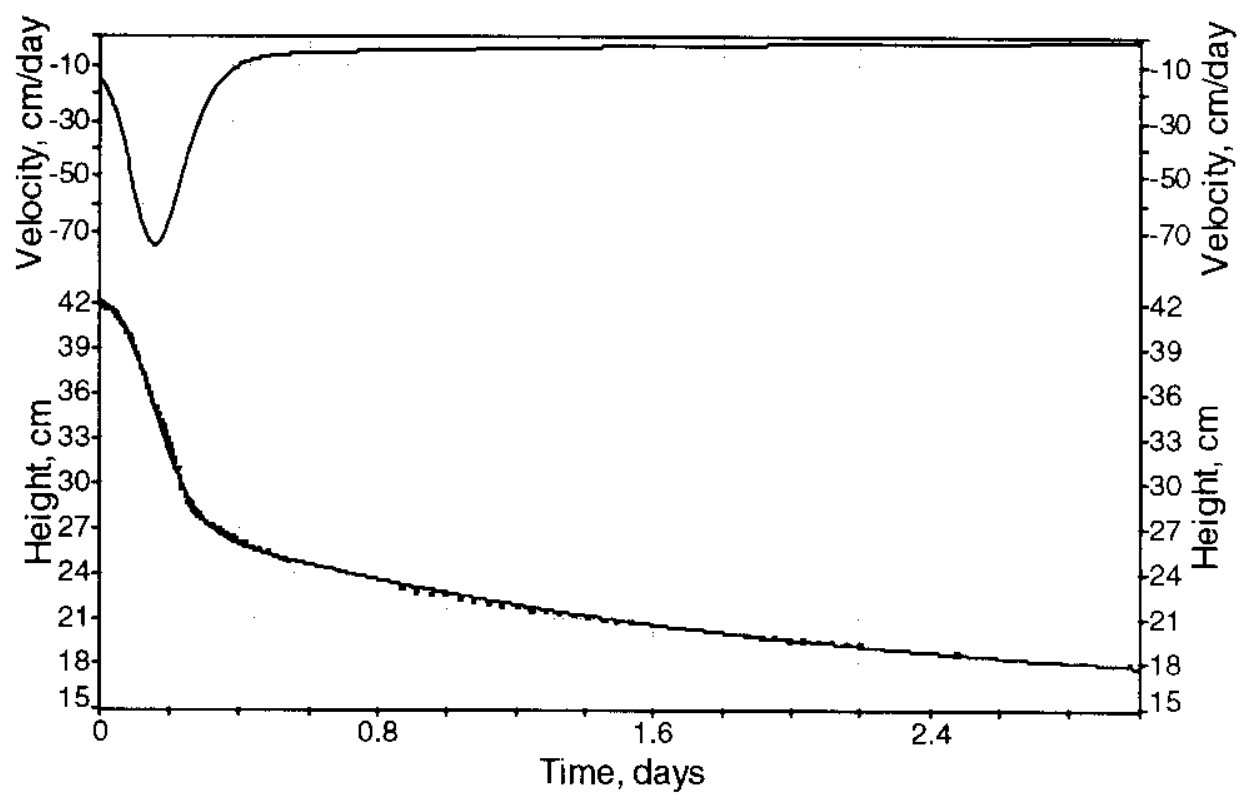

Diluted $\mathrm{Al}(\mathrm{OH})_{3}-\mathrm{Fe}(\mathrm{OH})_{3}$ Slurry $-2000 \mathrm{~mL}$

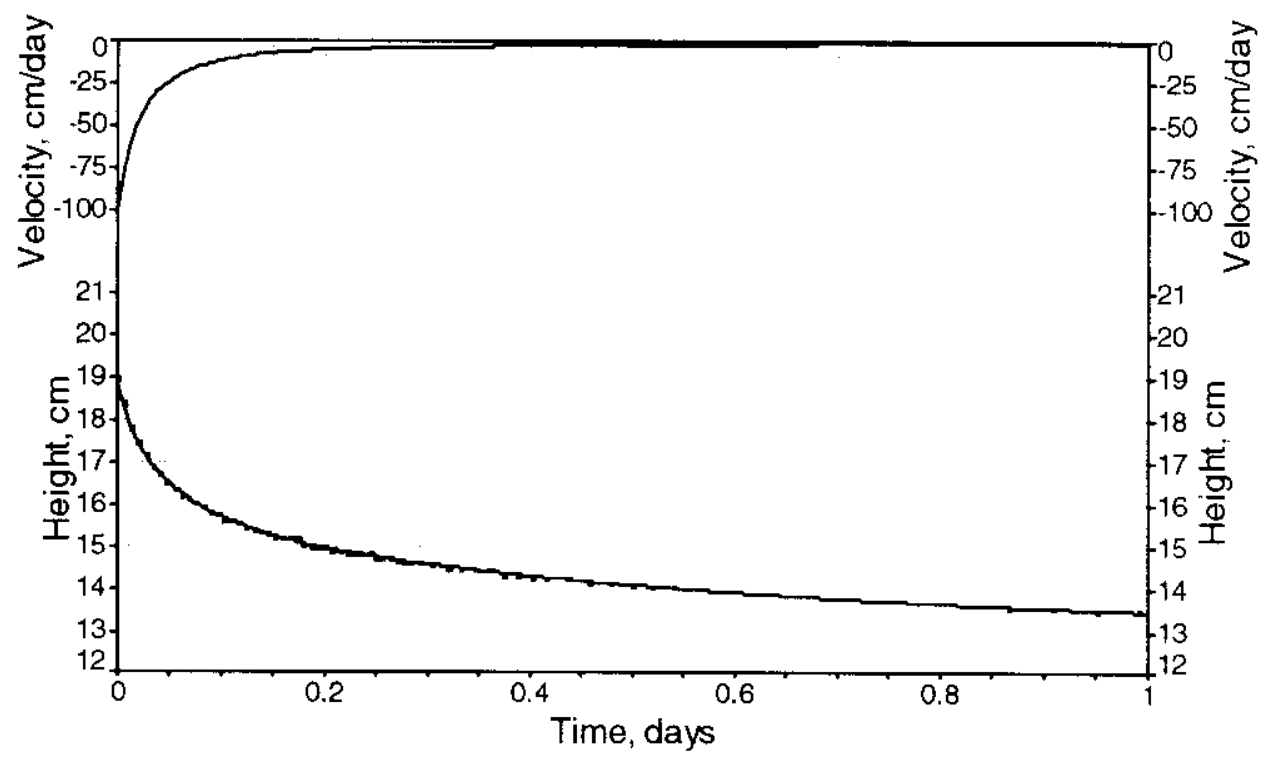

Undiluted $\mathrm{Al}(\mathrm{OH})_{3}-\mathrm{Fe}(\mathrm{OH})_{3}$ Slurry $-100 \mathrm{~mL}$ 
HNF-5177, Rev. 0

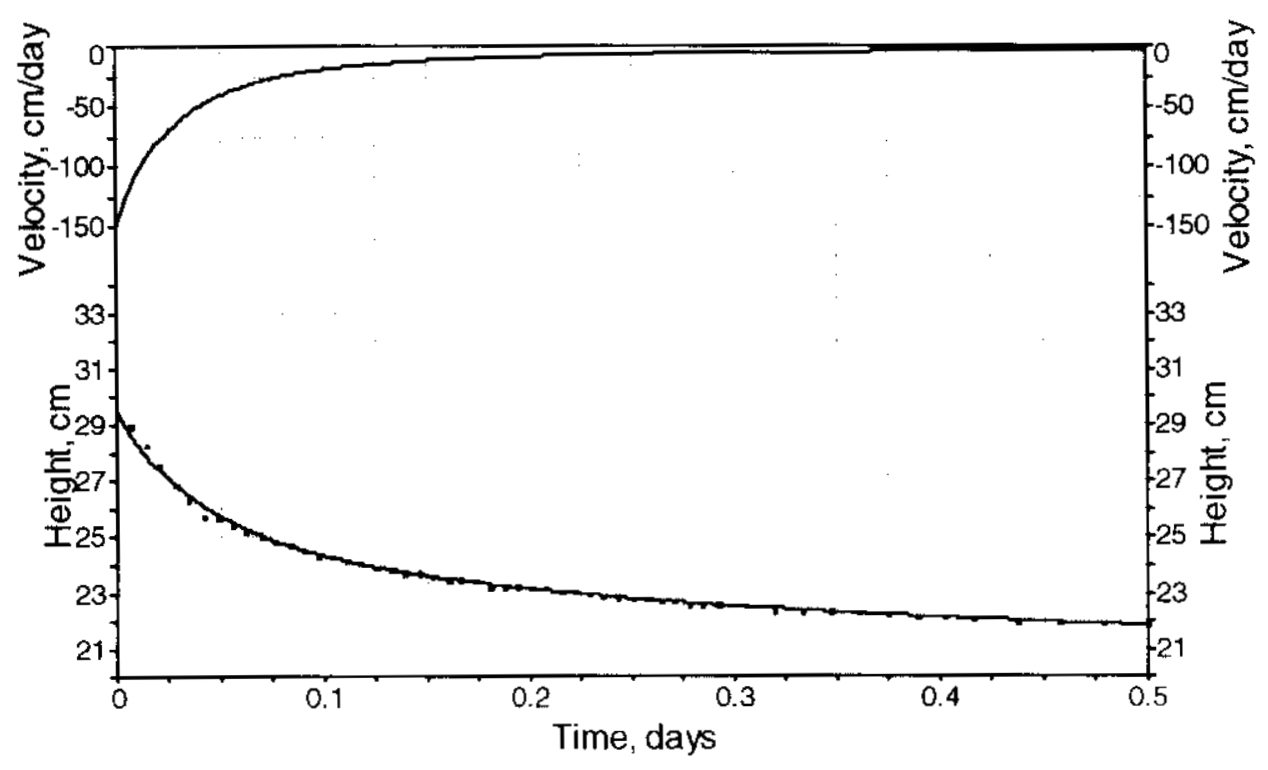

Undiluted $\mathrm{Al}(\mathrm{OH})_{3}-\mathrm{Fe}(\mathrm{OH})_{3}$ Slurry $-500 \mathrm{~mL}$

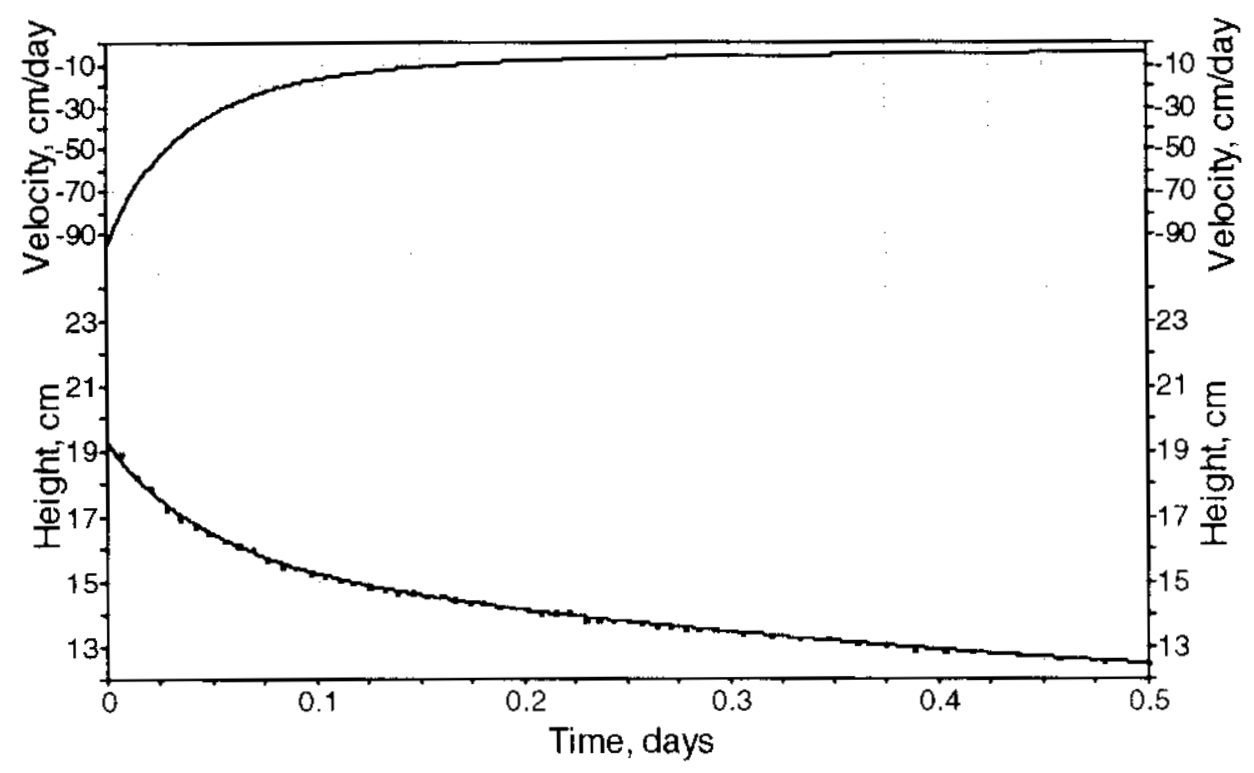

$\mathrm{Fe}(\mathrm{OH})_{3}$ Slurry $-100 \mathrm{~mL}$ 
HNF-5177, Rev. 0

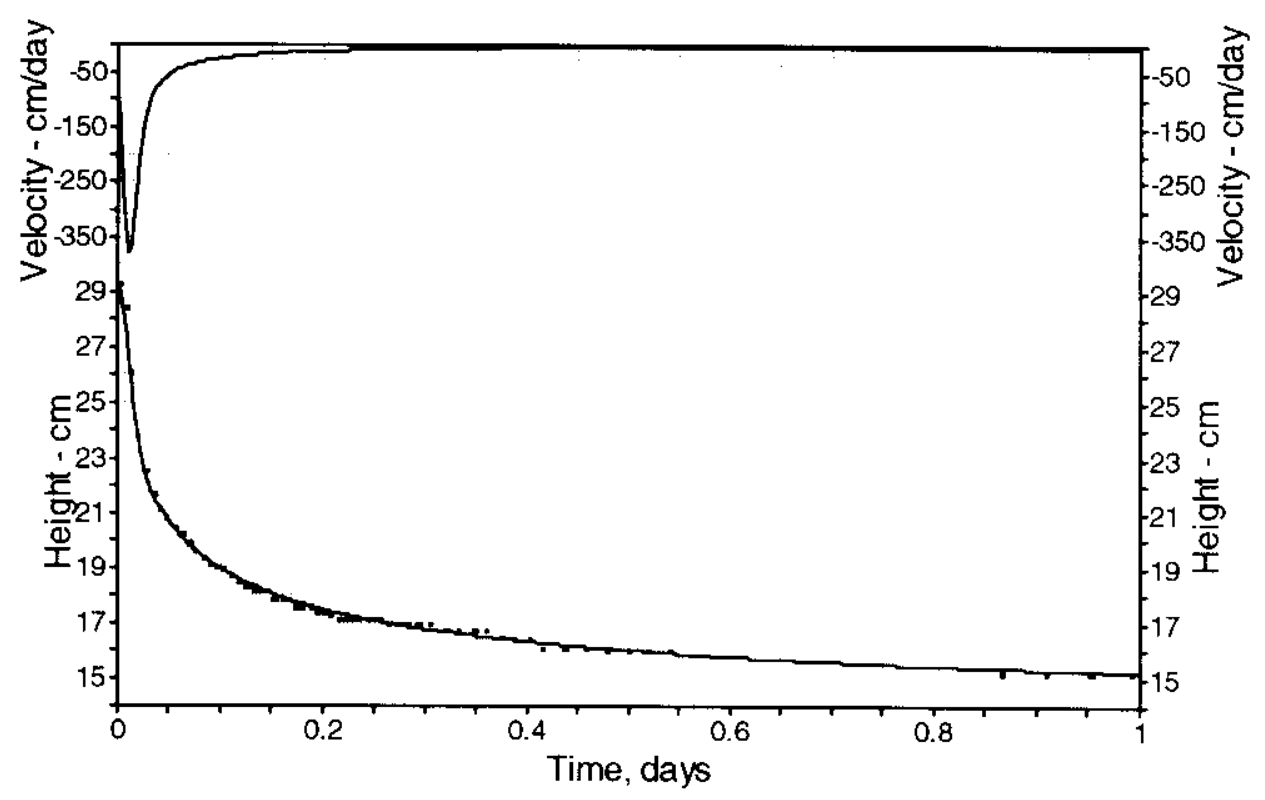

$\mathrm{Fe}(\mathrm{OH})_{3}$ Slurry $-500 \mathrm{~mL}$

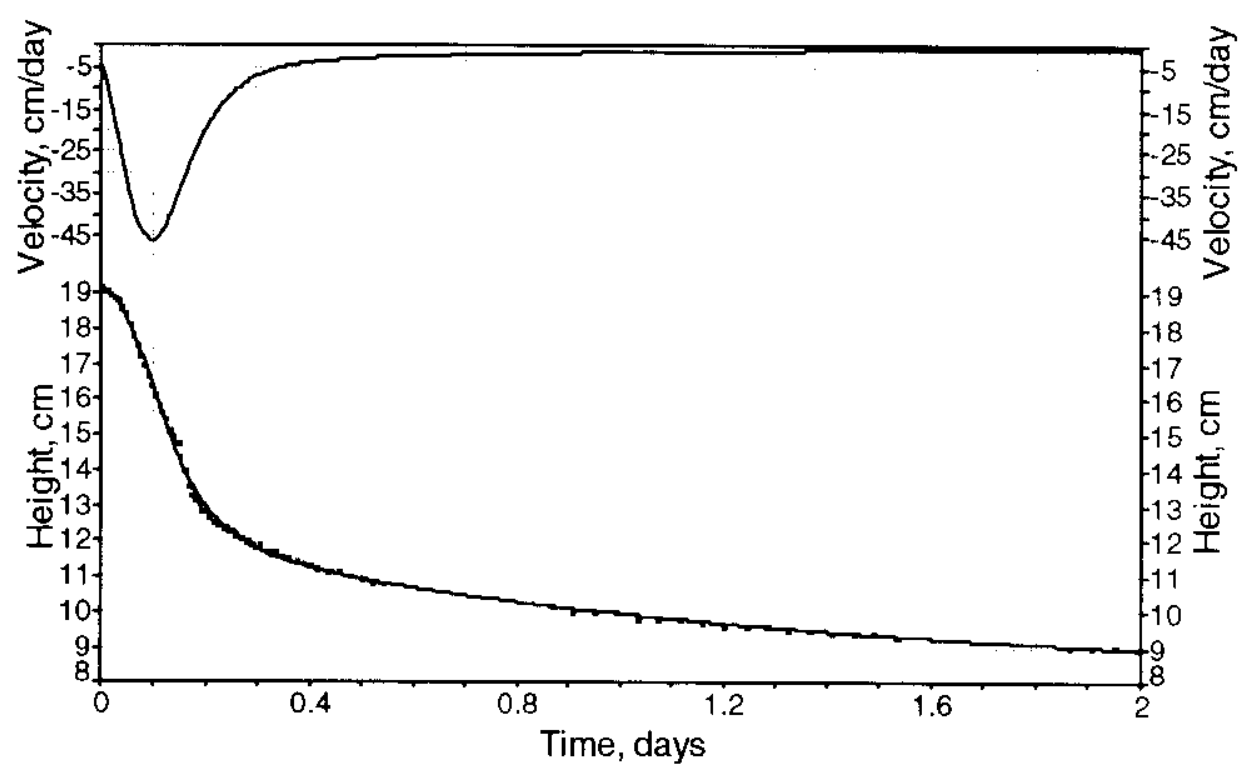

NCAW Simulant - $100 \mathrm{~mL}$ 
HNF-5177, Rev. 0

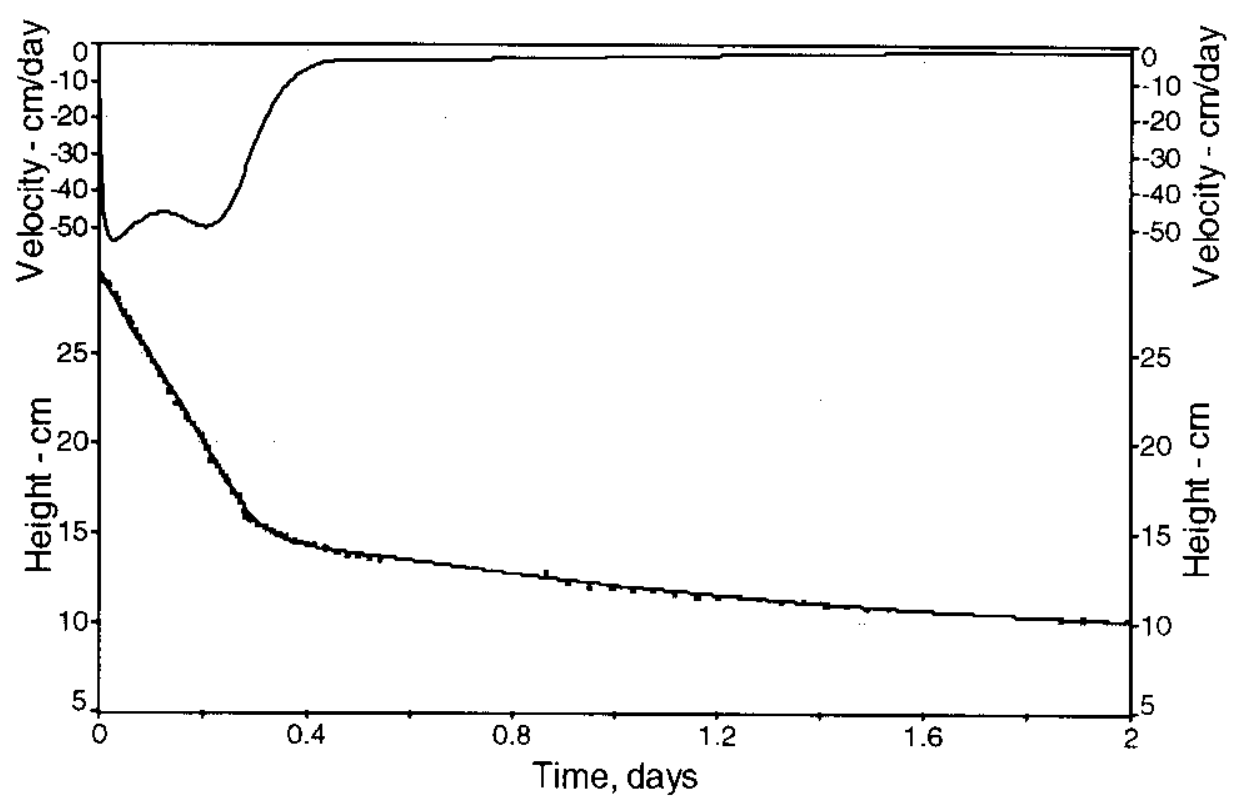

NCAW Simulant $-500 \mathrm{~mL}$

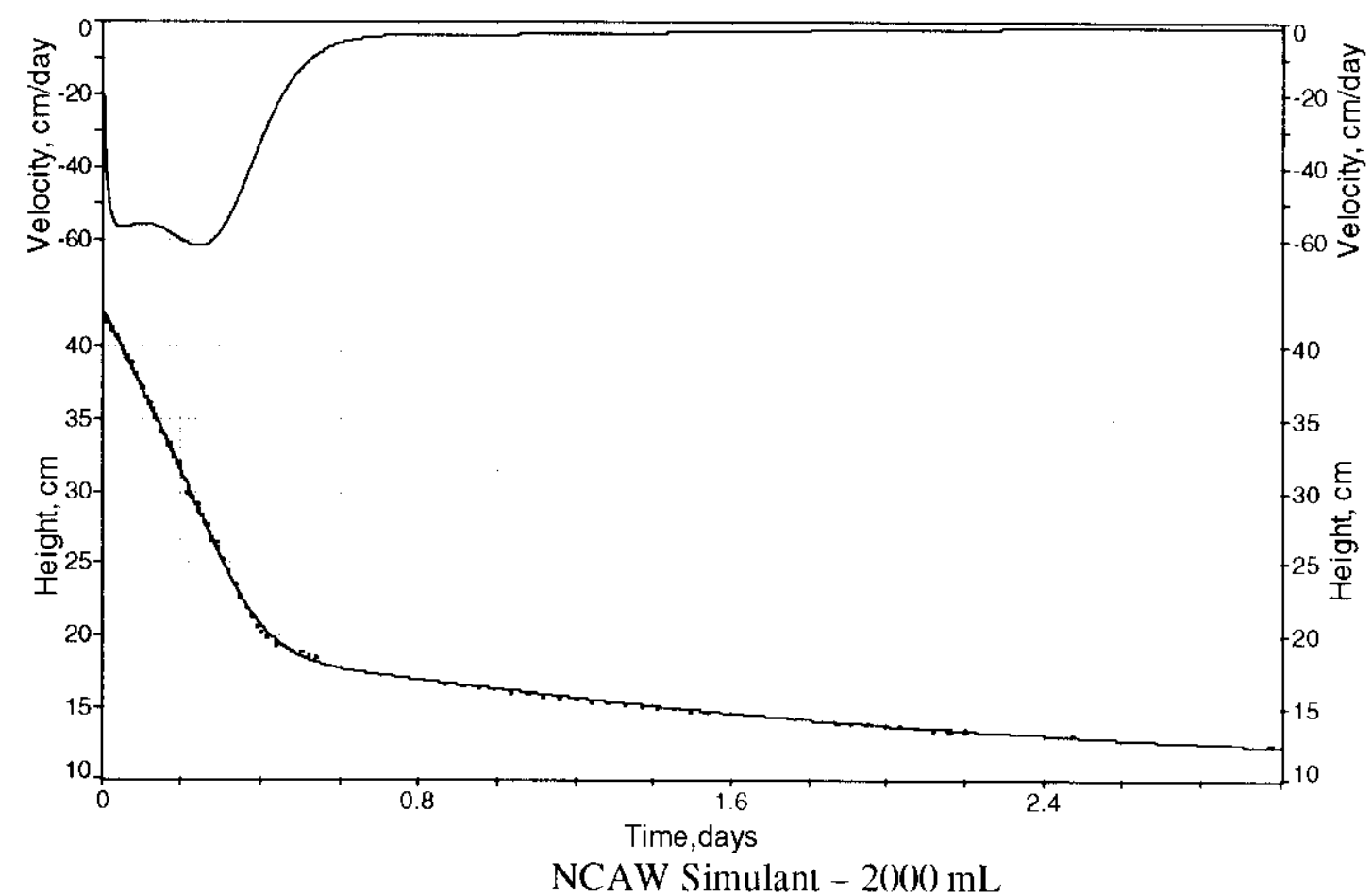


HNF-5177, Rev. 0

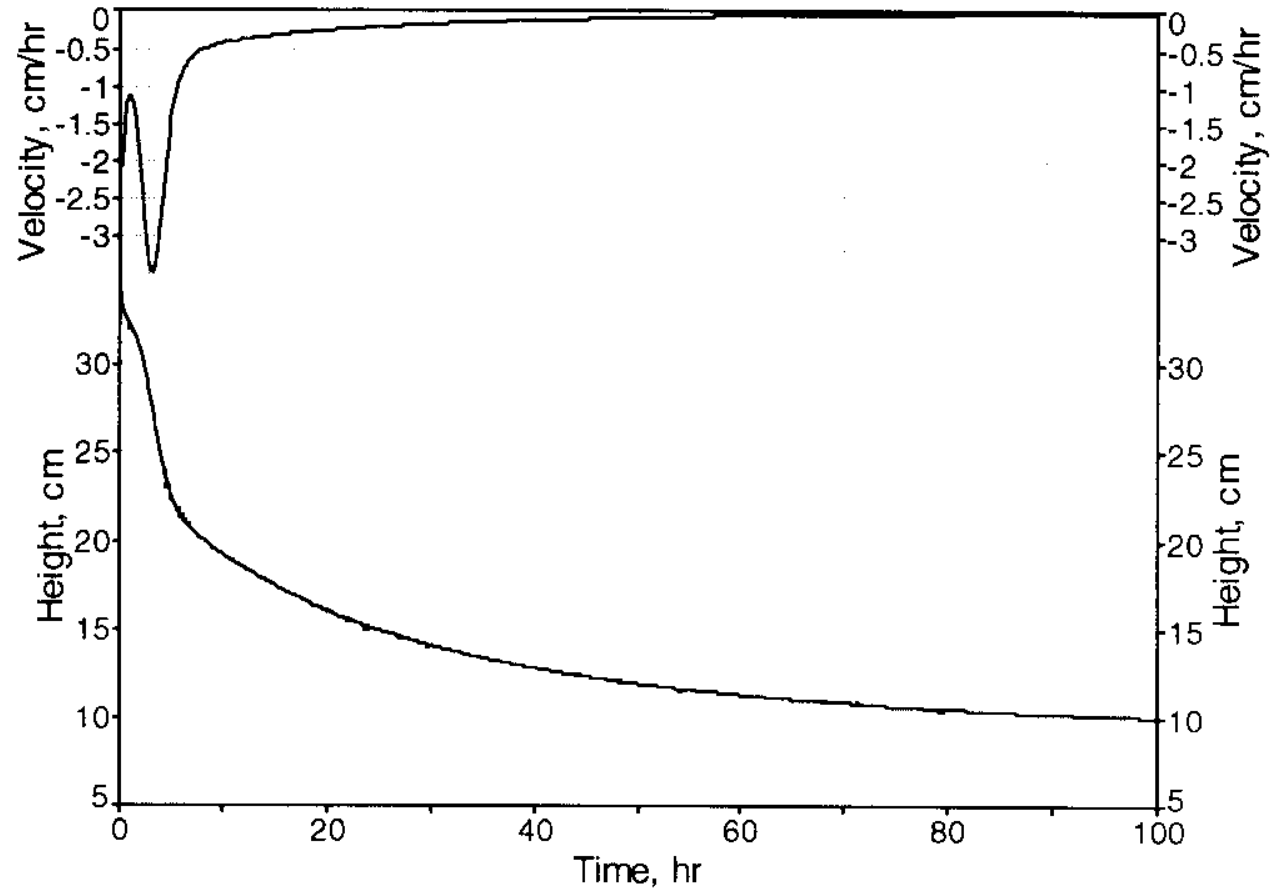

NCAW Simulant - 1Gal., Vessel 1, Run 1

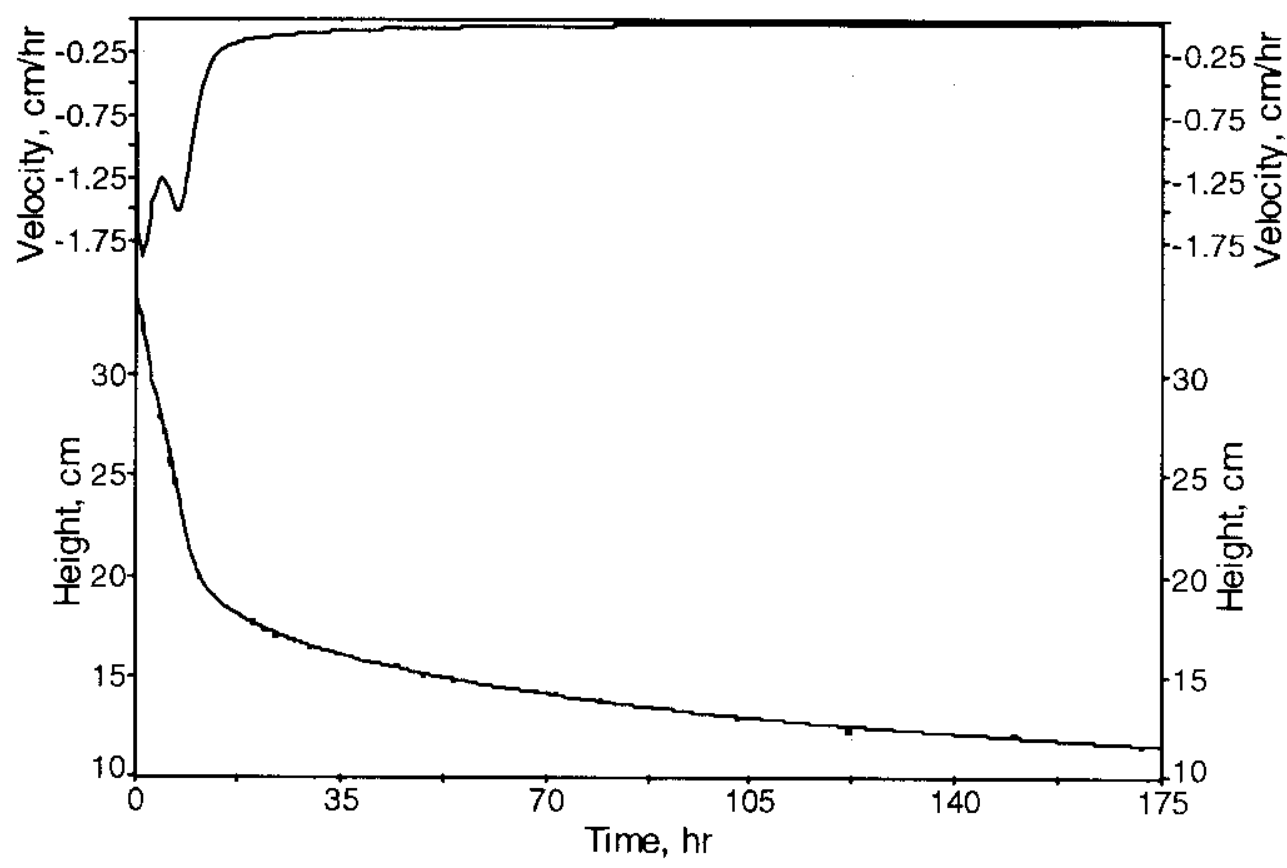

NCAW Simulant - 1 Gal., Vessel 1, Wash 1

A-6 
HNF-5177, Rev. 0

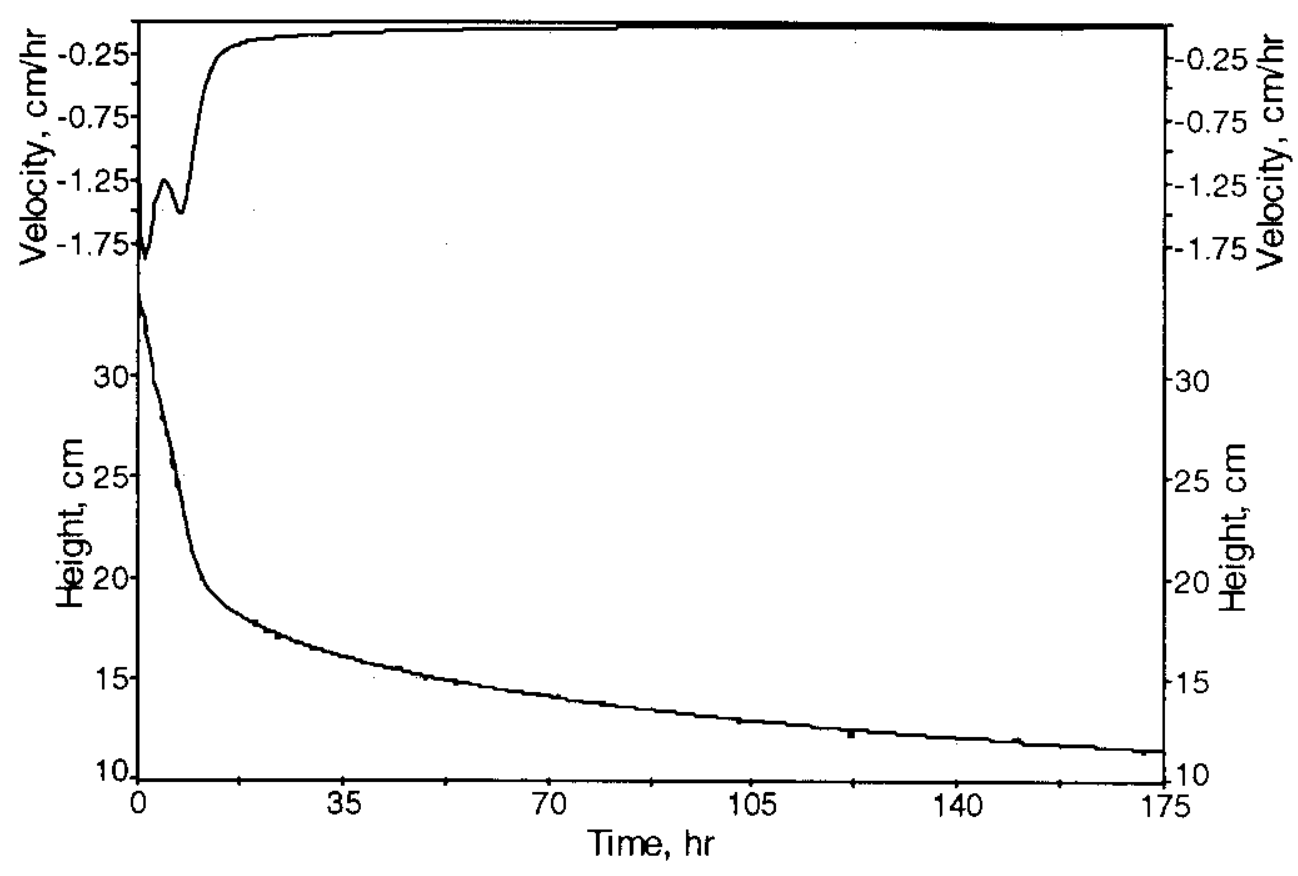

NCAW Simulant - 1 Gal., Vessel 2, Run 1

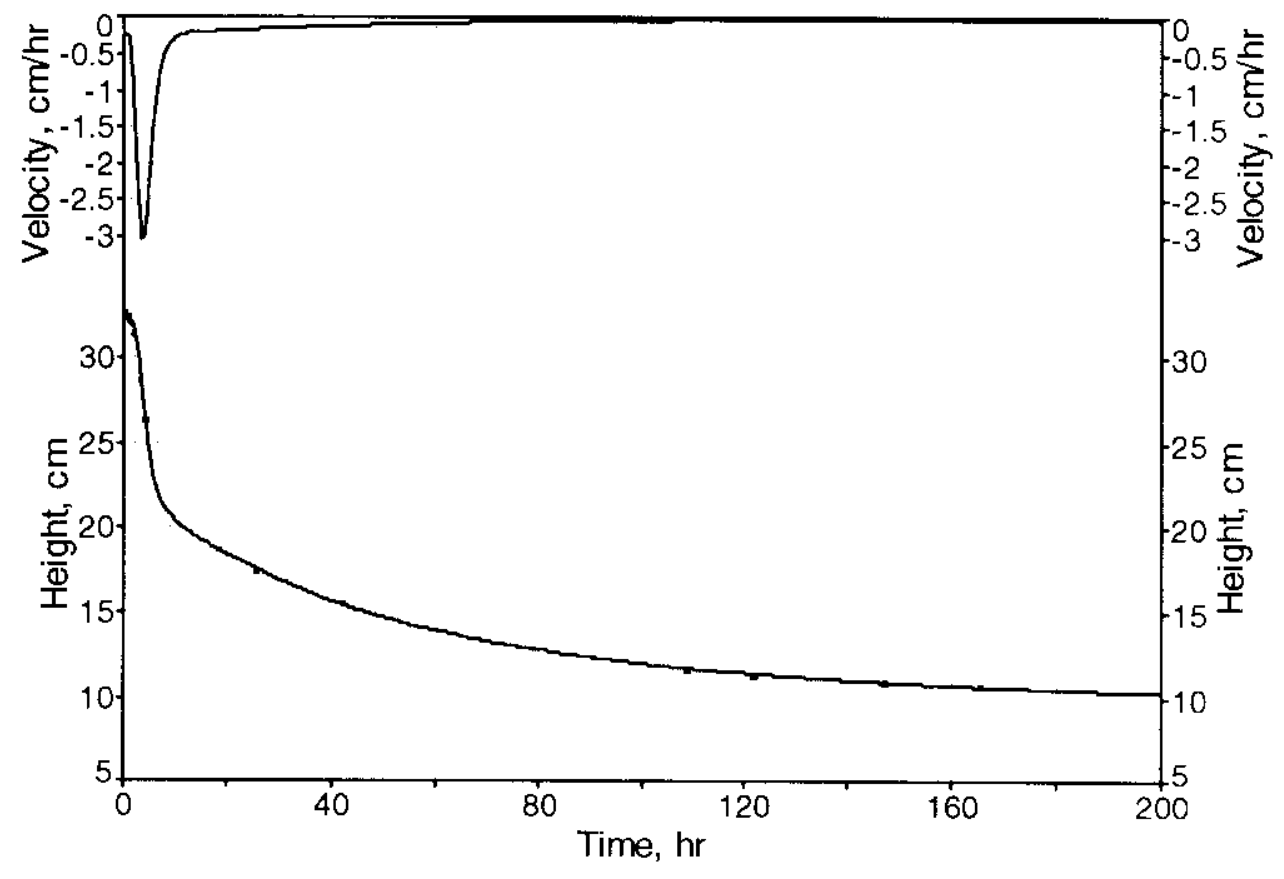

NCAW Simulant - 1 Gal., Vessel 2, Wash 1

A-7 
HNF-5177, Rev. 0

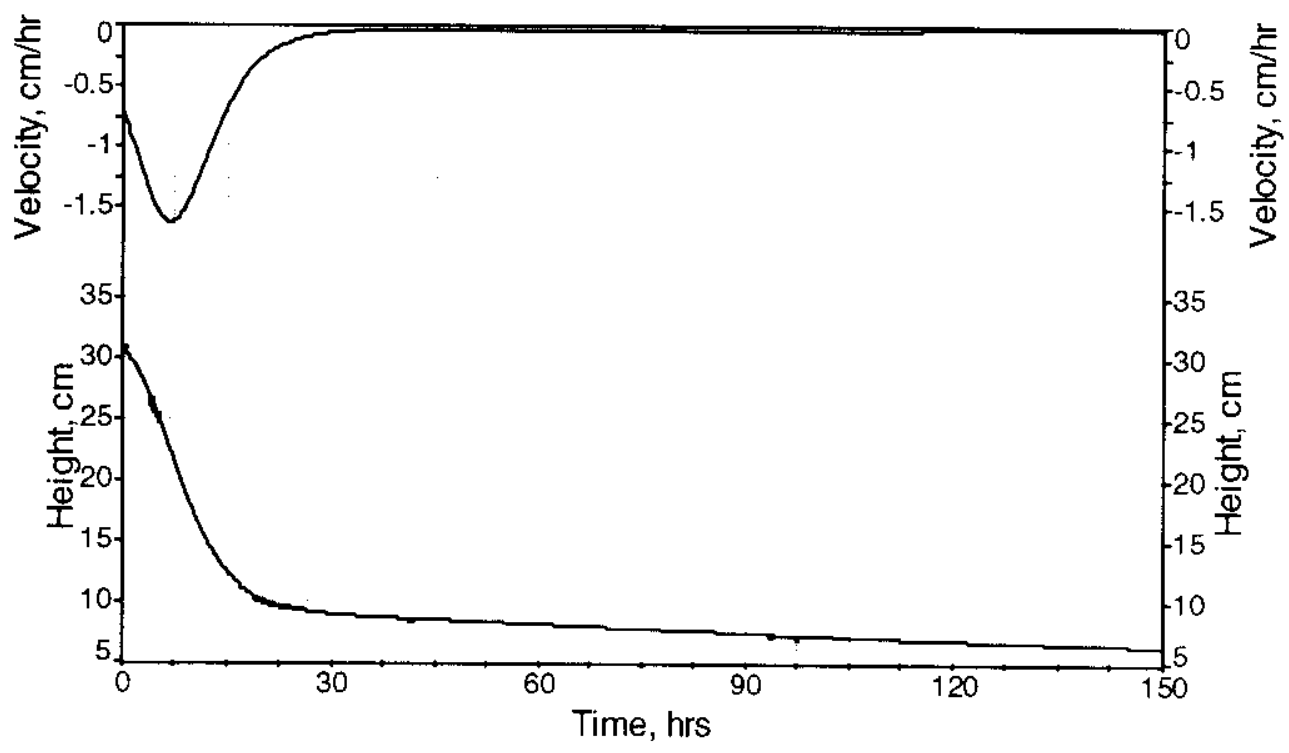

$\mathrm{Fe}(\mathrm{OH})_{3}$ Slurry - $30 \mathrm{Ft}$. Column

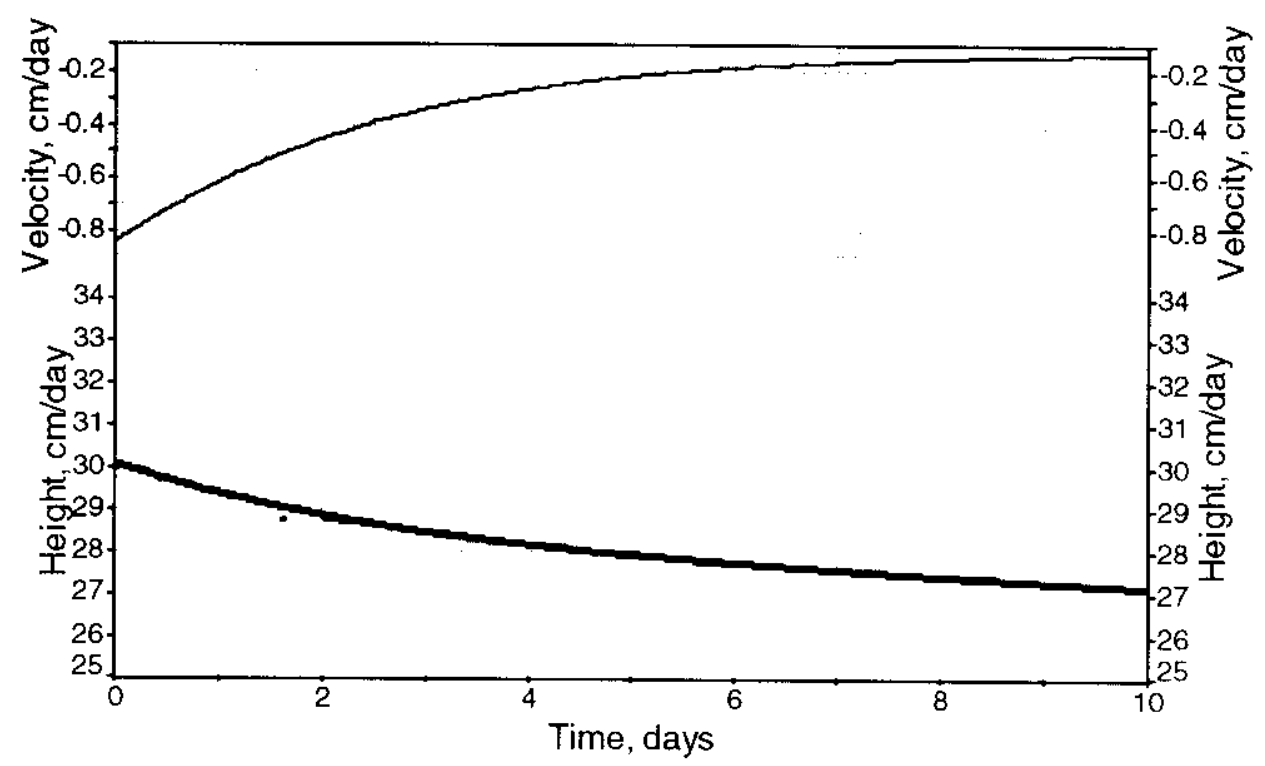

Undiluted $\mathrm{Al}(\mathrm{OH})_{3}-\mathrm{Fe}(\mathrm{OH})_{3}$ Slurry - 30 Ft. Column 
HNF-5177, Rev. 0

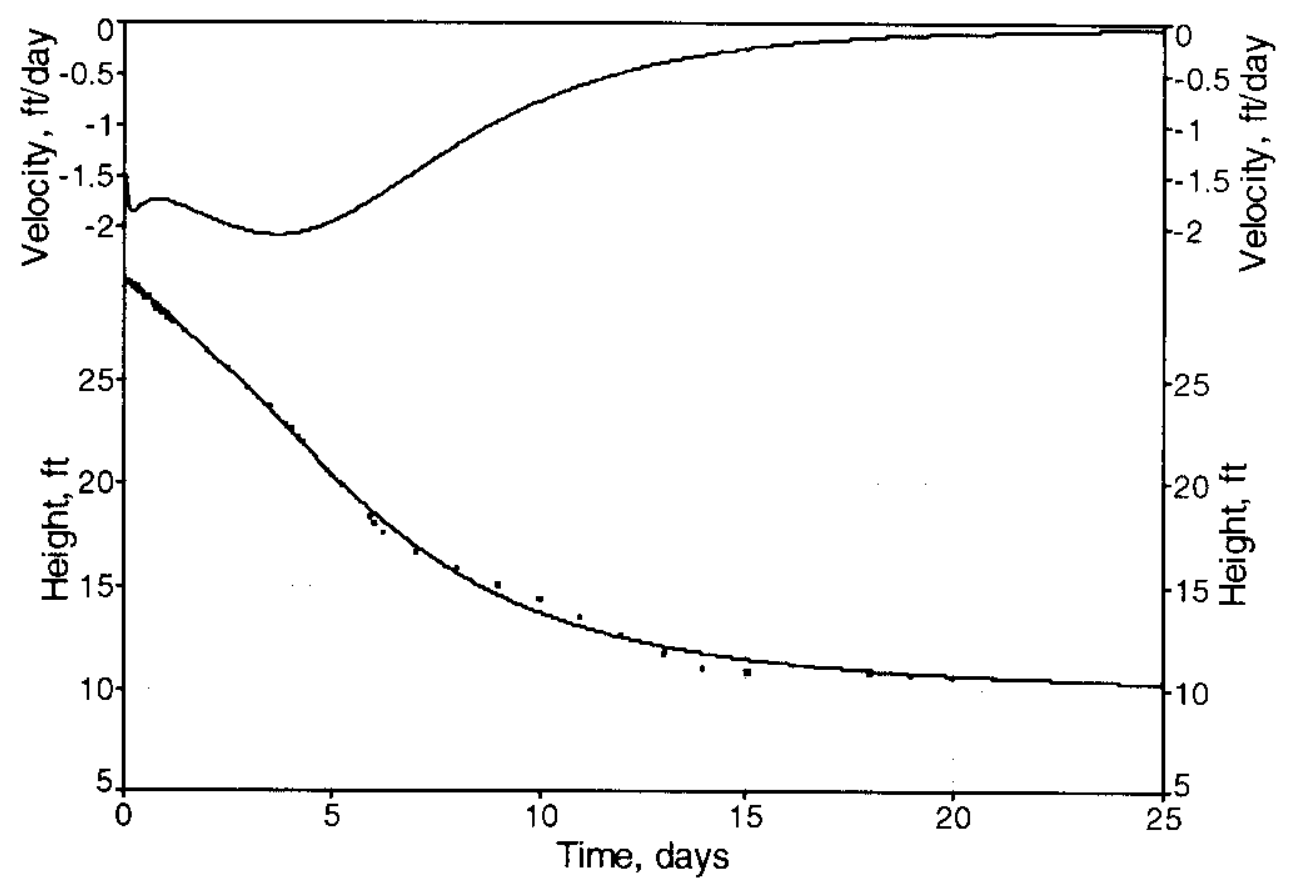

Diluted $\mathrm{Al}(\mathrm{OH})_{3}-\mathrm{Fe}(\mathrm{OH})_{3}$ Slurry $-30 \mathrm{Ft}$. Column 
HNF-5177, Rev. 0

\section{APPENDIX B}

TANK WASTE SETTLING TESTS

\section{PACIFIC NORTHWEST NATIONAL LABORATORY}

MINIPLANT 
HNF-5177, Rev. 0

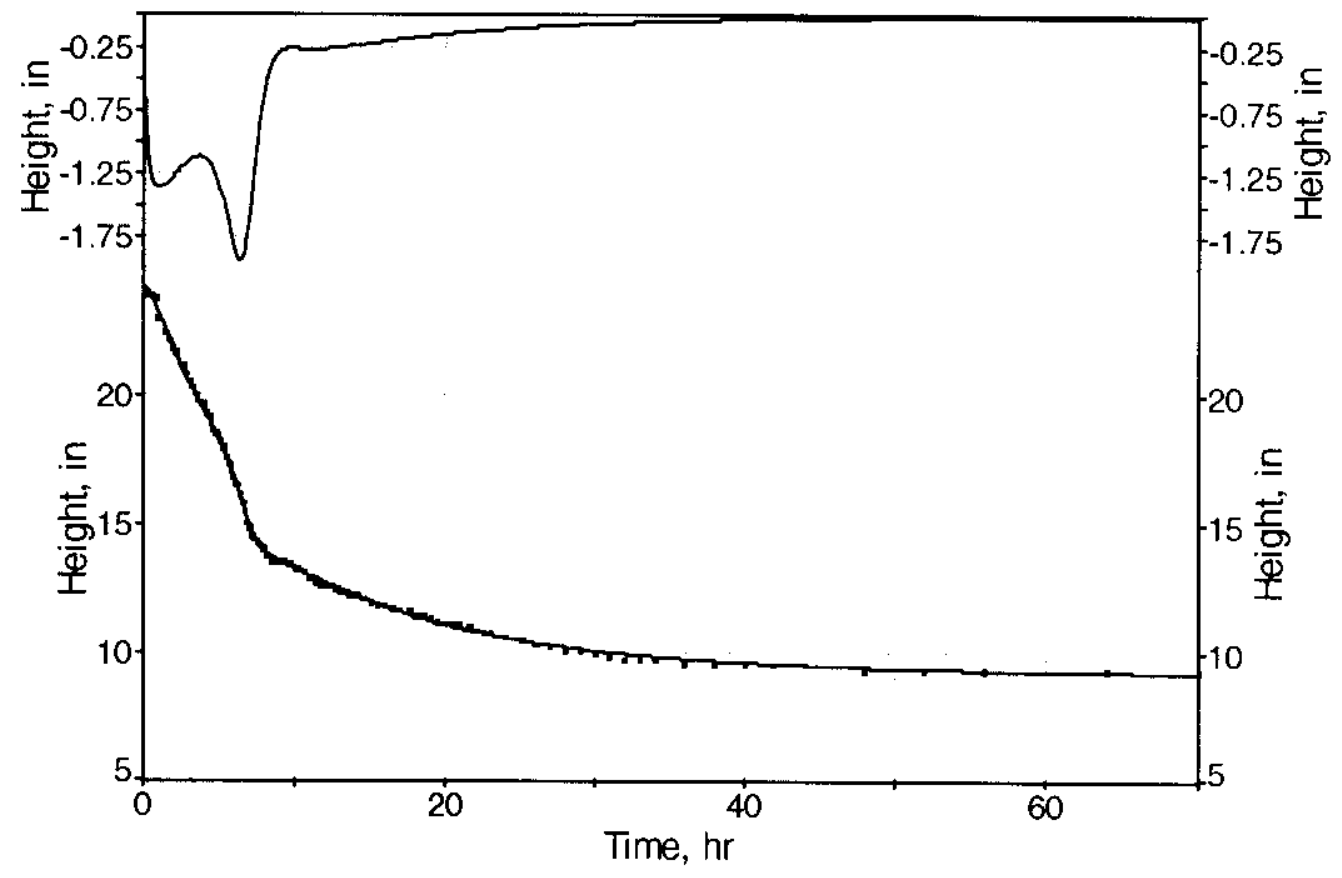

C-106 Leach 1 - miniplant

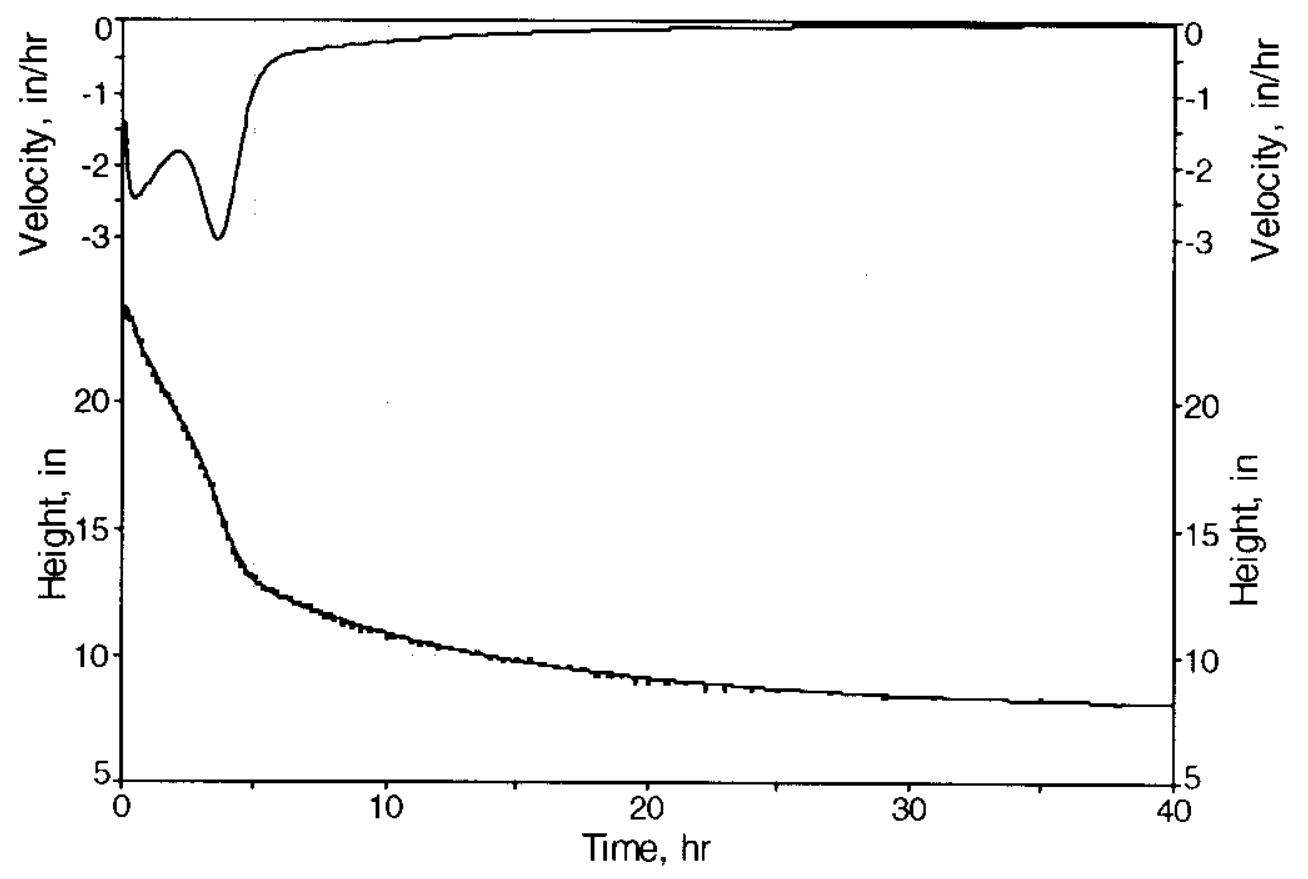

C-106 Leach 2 - miniplant

B-1 
HNF-5177, Rev. 0

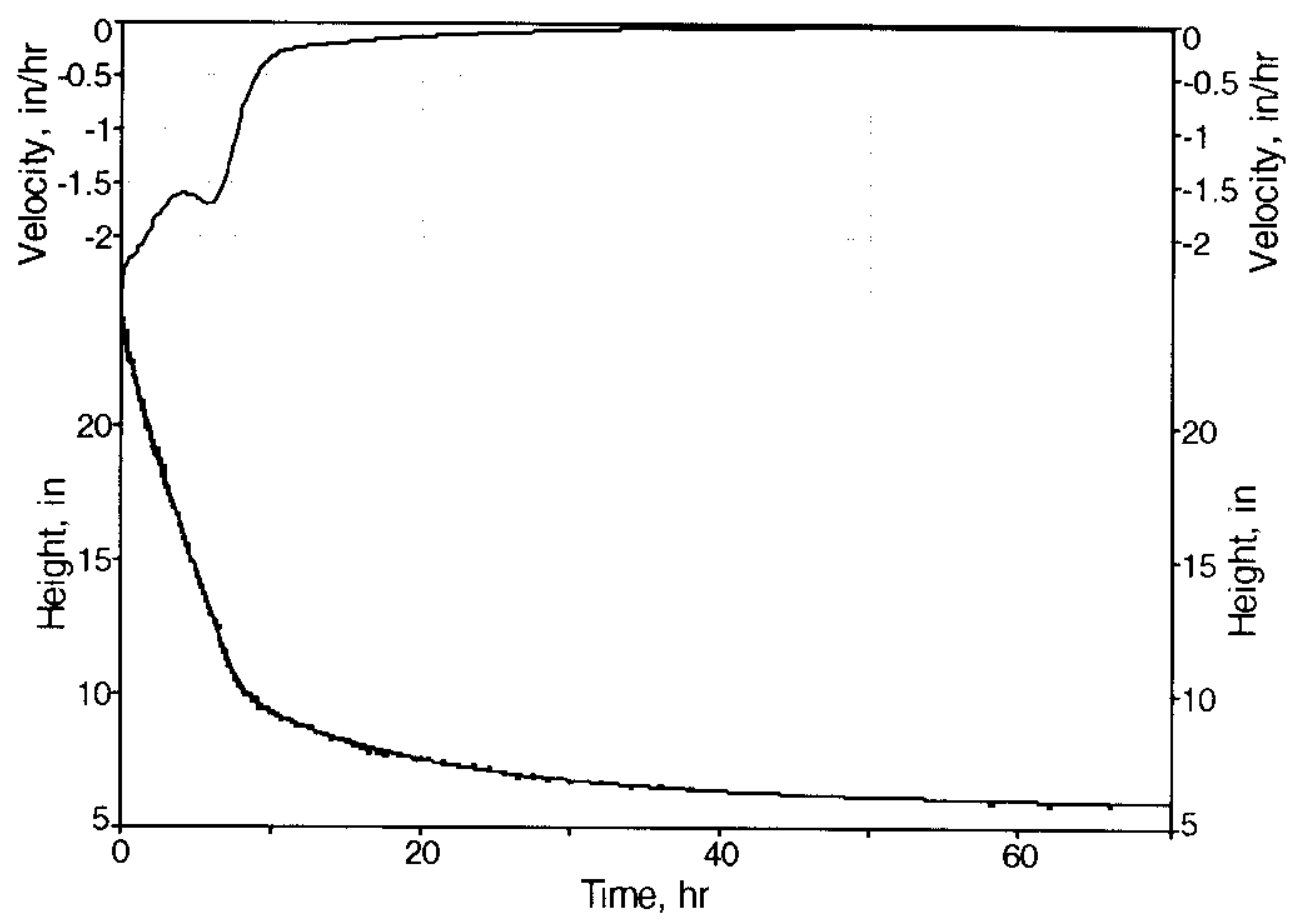

C-106 Water Wash 1 - miniplant 
HNF-5177, Rev. 0

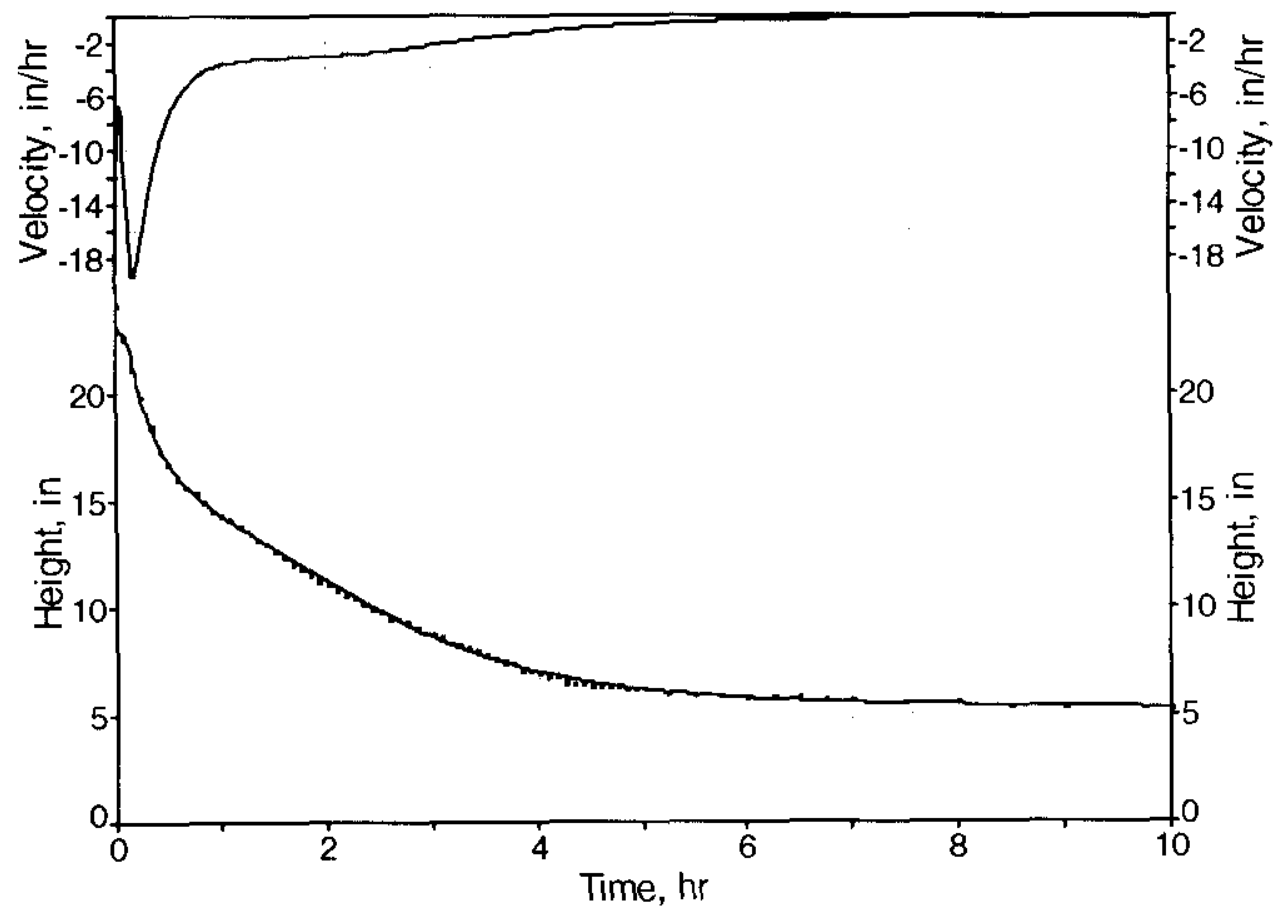

C-106 Water Wash 2 - miniplant

B-3 
HNF-5177, Rev. 0

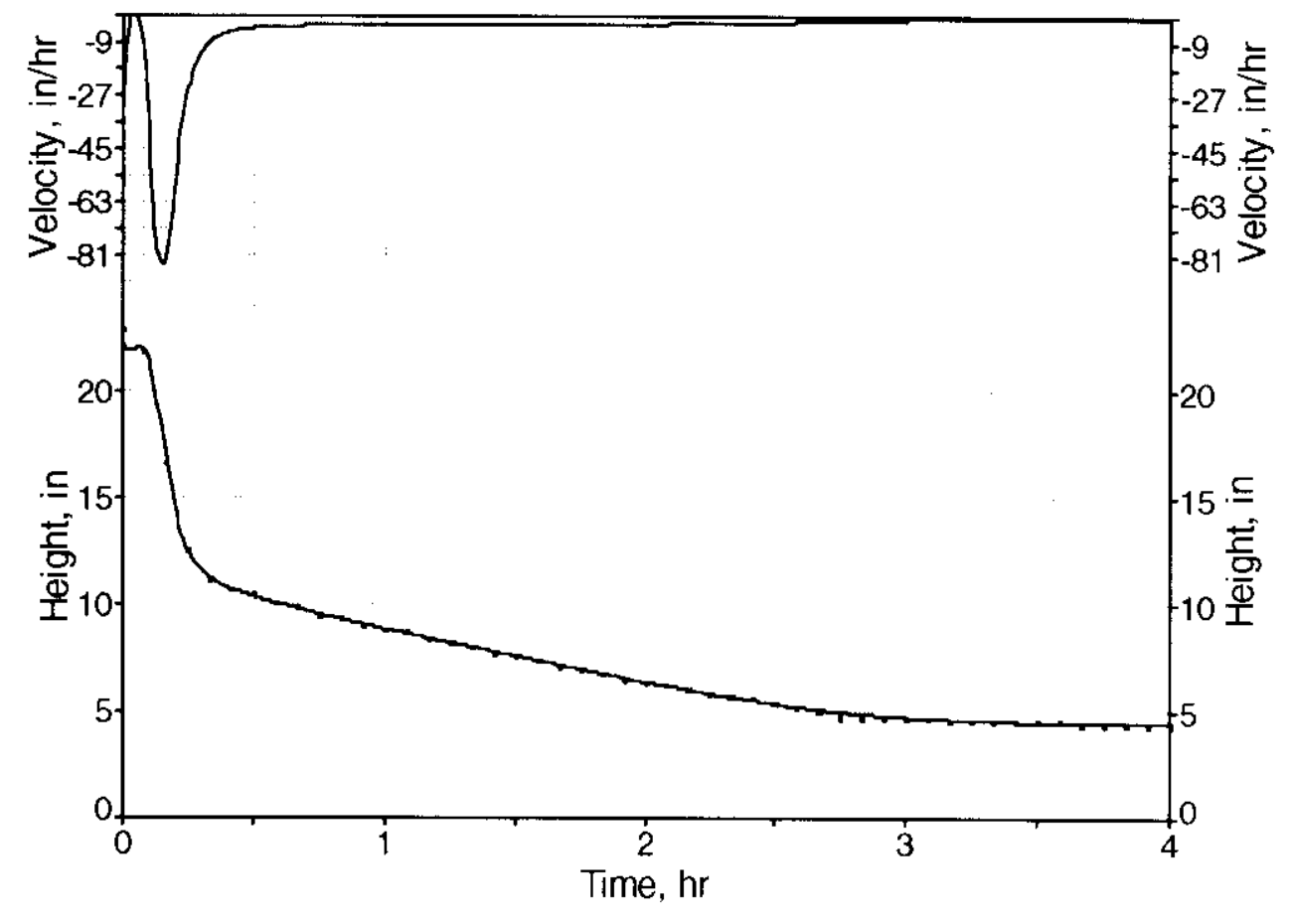

C-106 Water Wash 3 - Miniplant 
HNF-5177, Rev. 0

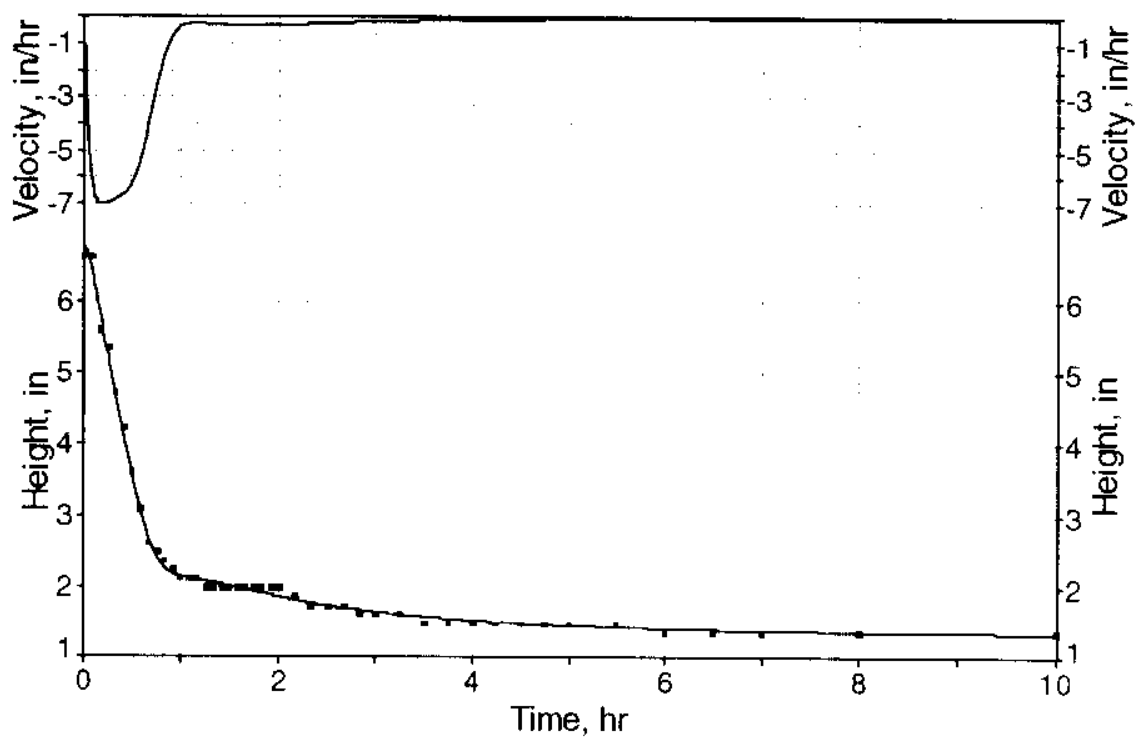

C-107 Wash 2, 4.5\% Solids, 50 C - $1350 \mathrm{ml}$

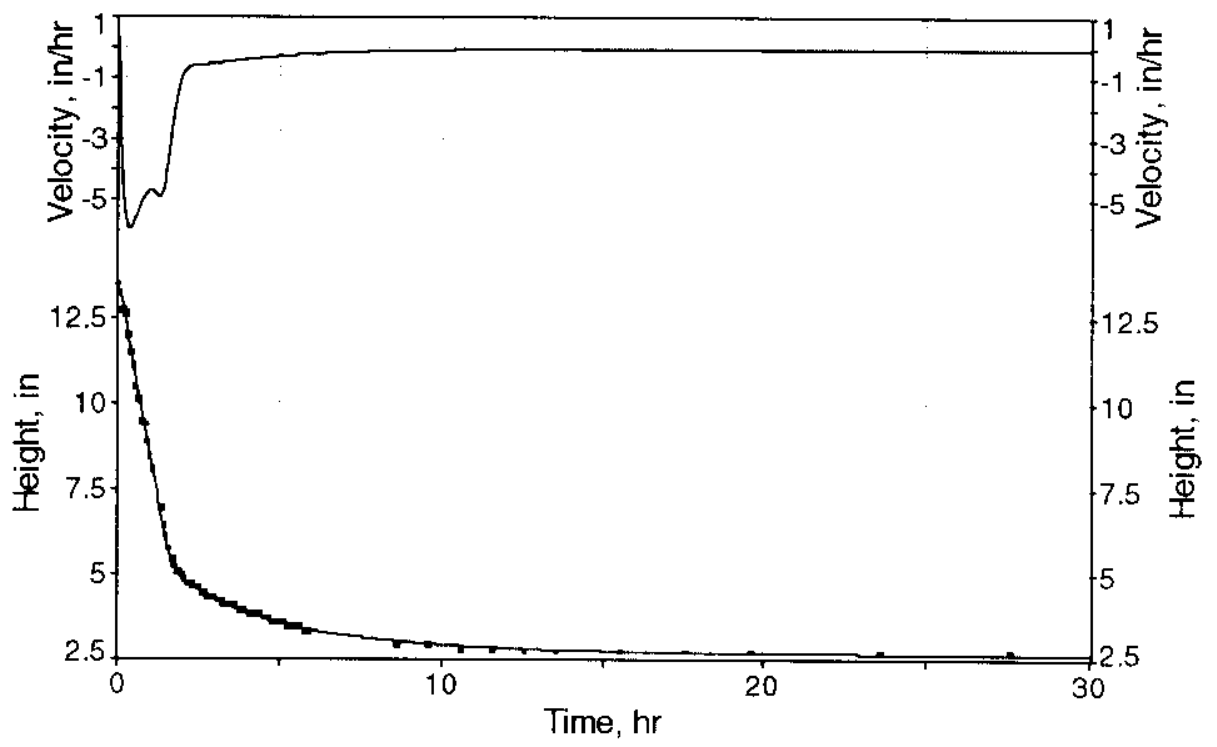

C-107 Wash 2, 4.5\% Solids, $50 \mathrm{C}-2750 \mathrm{ml}$ 
HNF-5177, Rev. 0

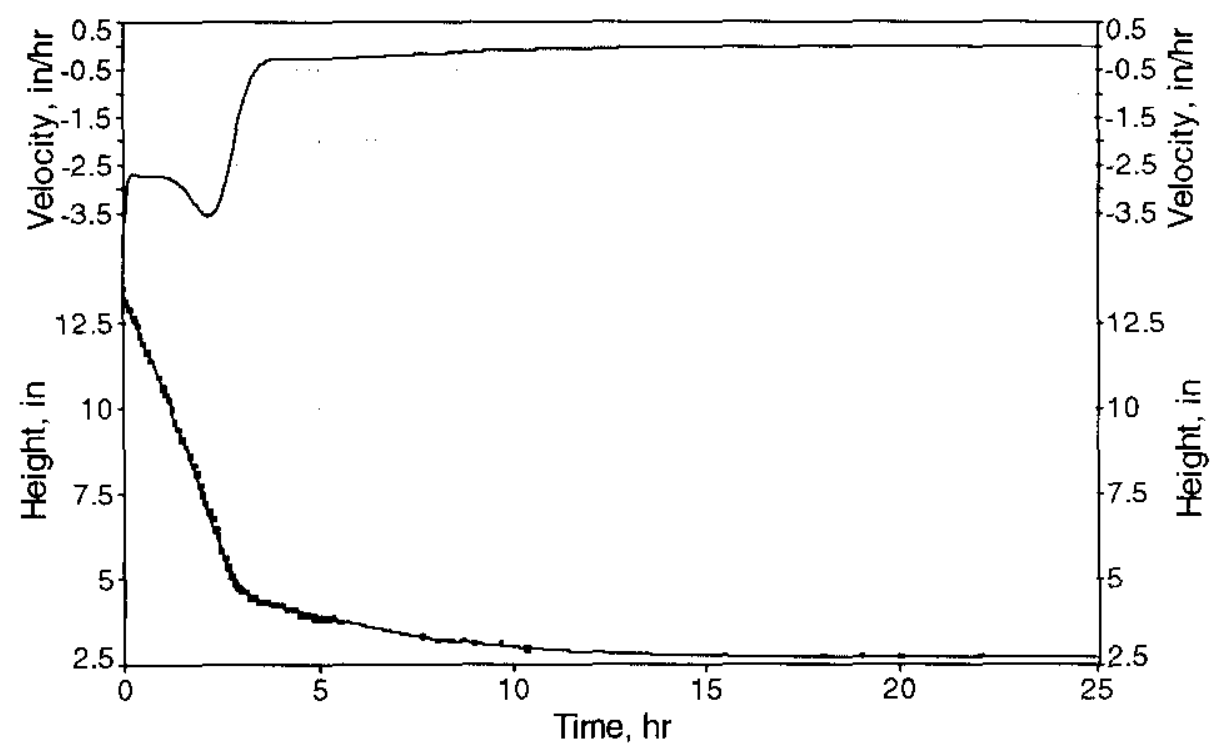

C-107 Wash 2, 4.5\% Solids, 25 C - $2750 \mathrm{ml}$

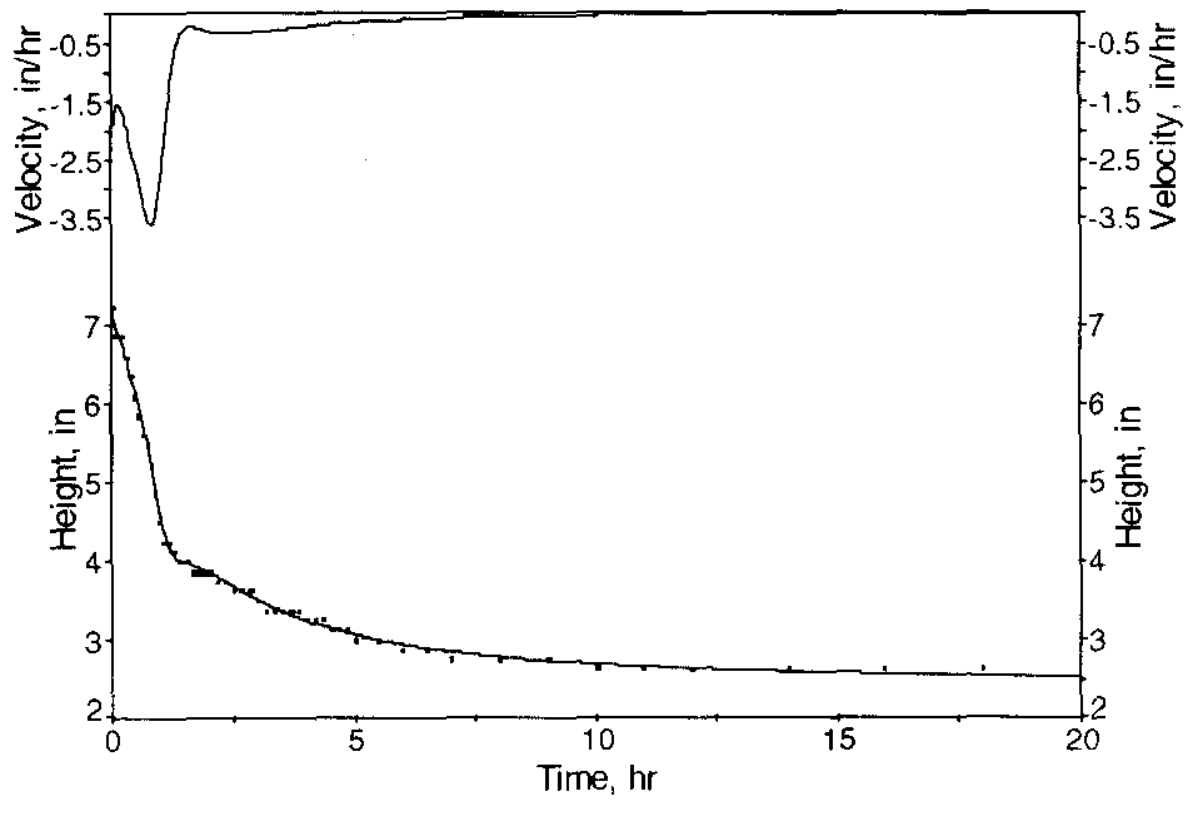

C-107 Wash 2, 8\% Solids, $50 \mathrm{C}-1478 \mathrm{ml}$ 
HNF-5177, Rev. ()

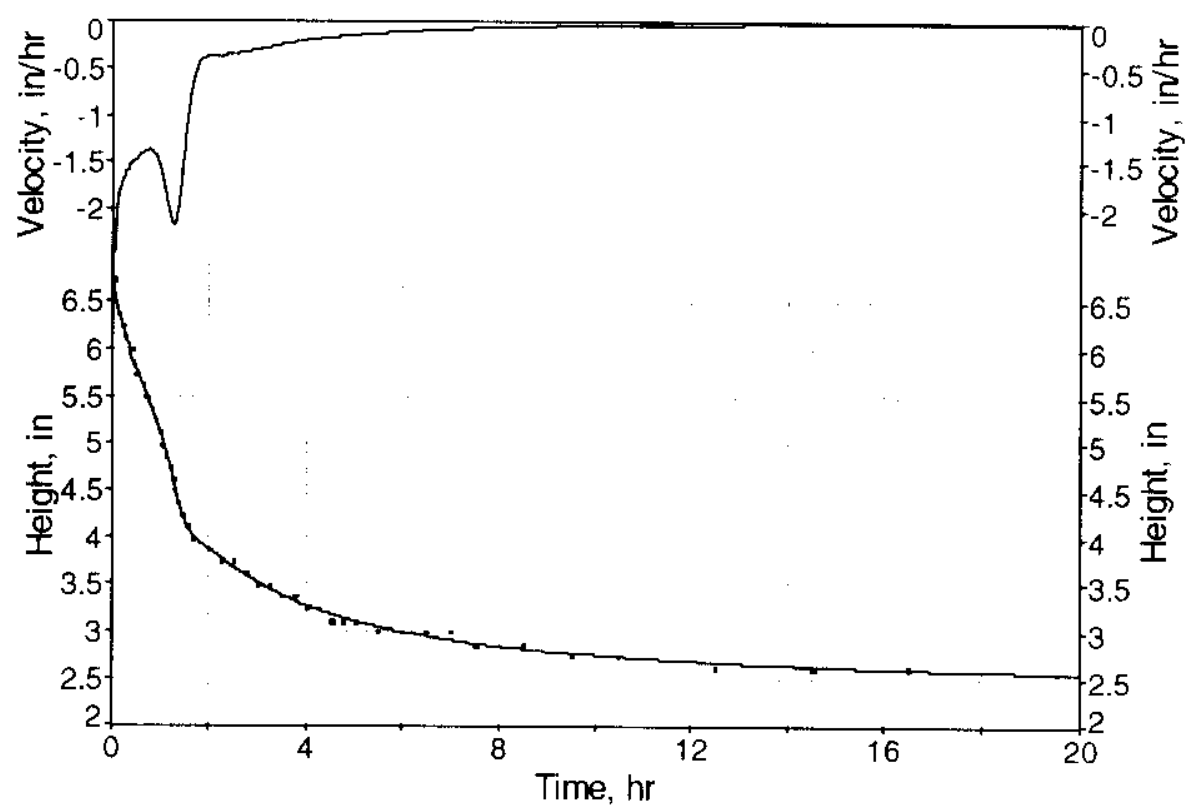

C-107 Wash 3, 9\% Solids, 25 C $-1376 \mathrm{ml}$

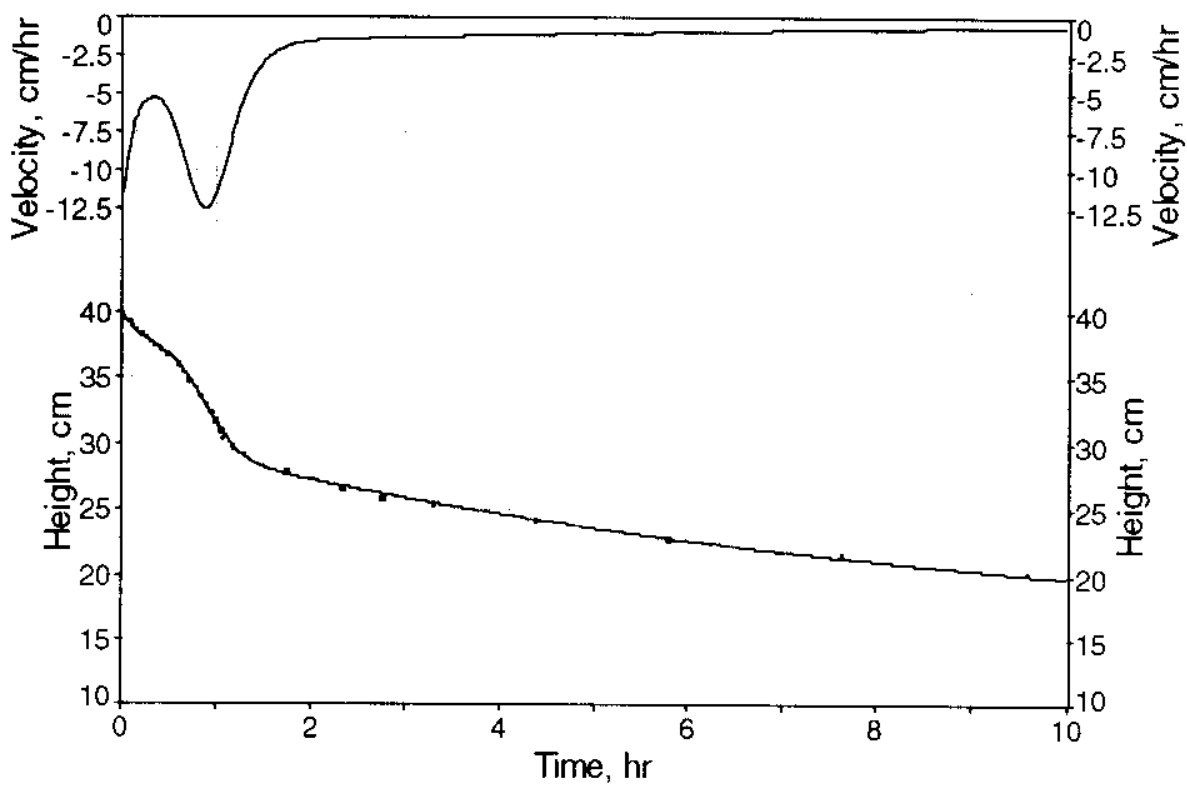

S-107 Retrieval Wash 1 - miniplant 
HNF-5177, Rev. 0

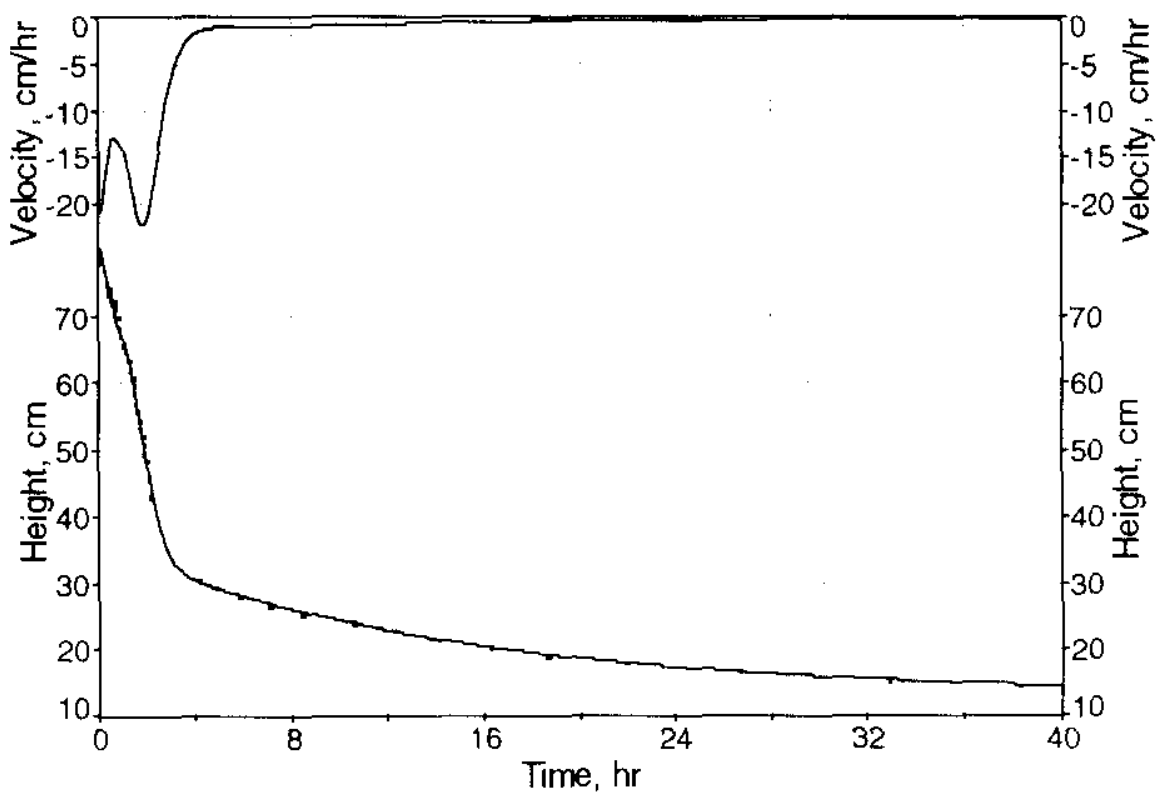

S-107 Retrieval Wash 2 - miniplant

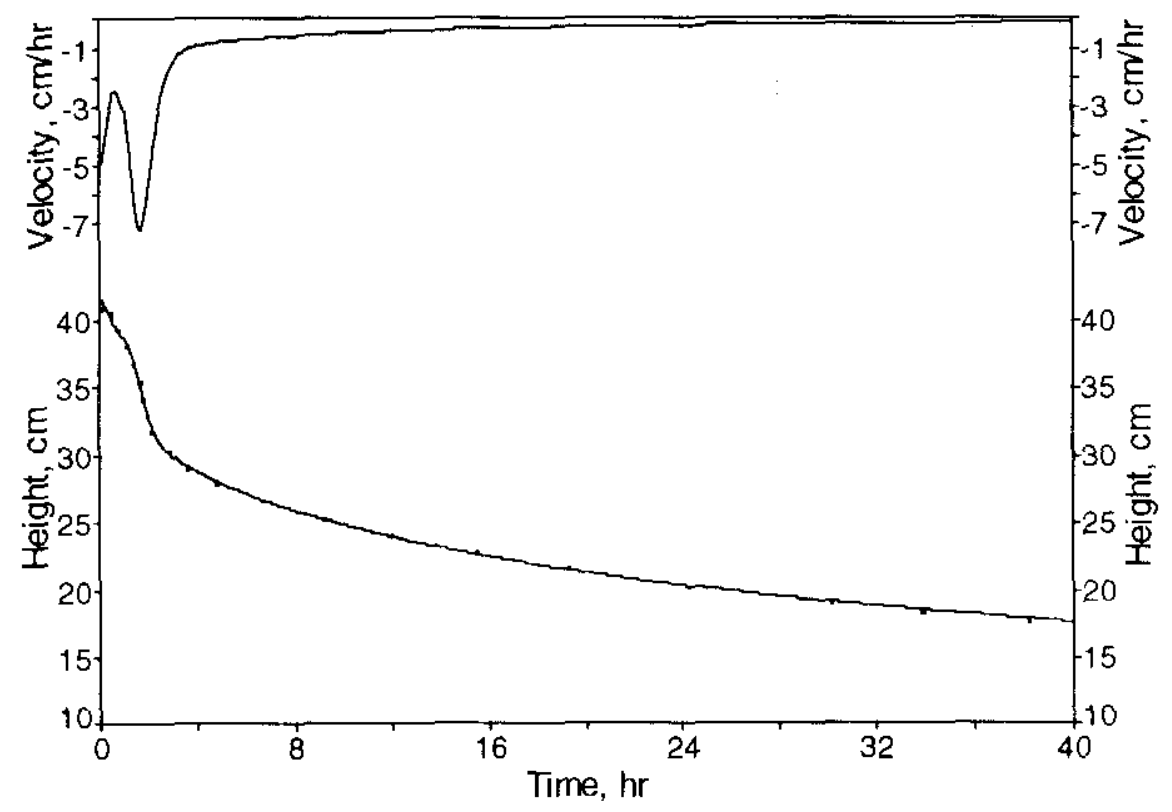

S-107 Caustic Leach 1 - miniplant 
HNF-5177, Rev. 0

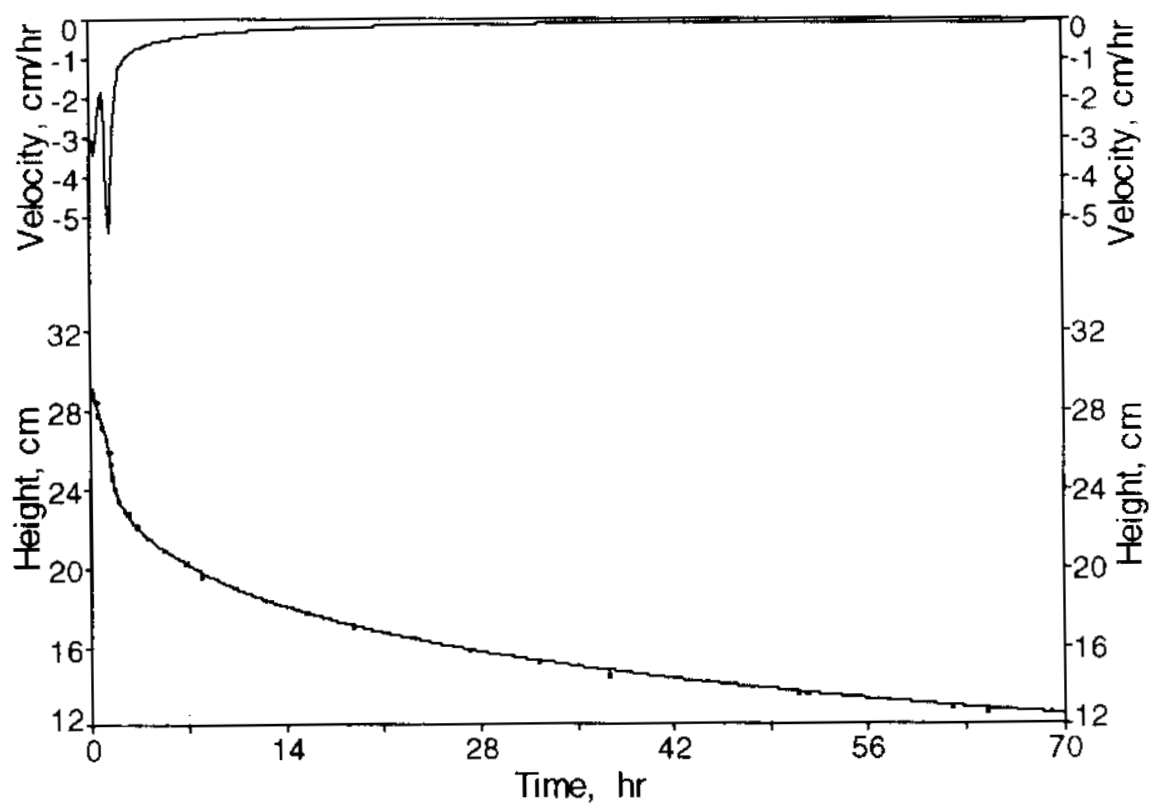

S-107 Caustic Leach 2 - miniplant

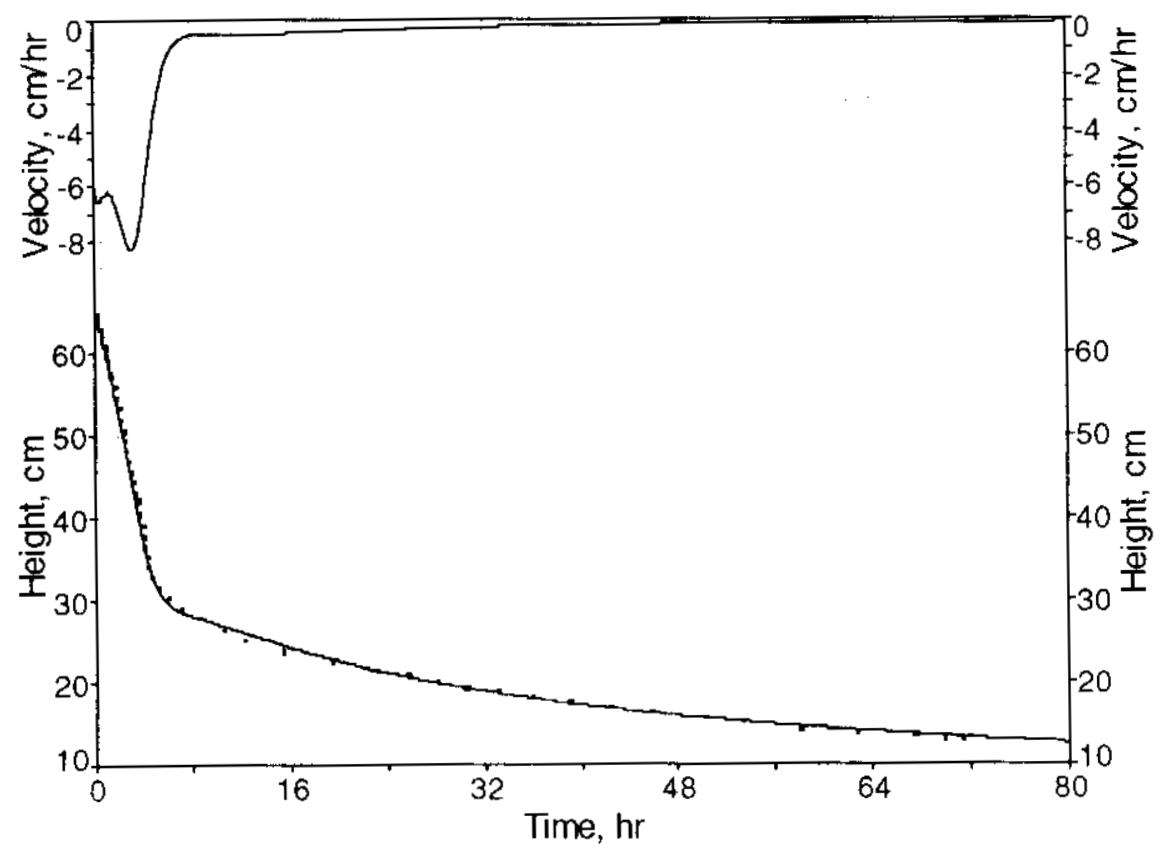

S-107 Caustic Leach 2, Part 2 - miniplant 
HNF-5177, Rev. 0

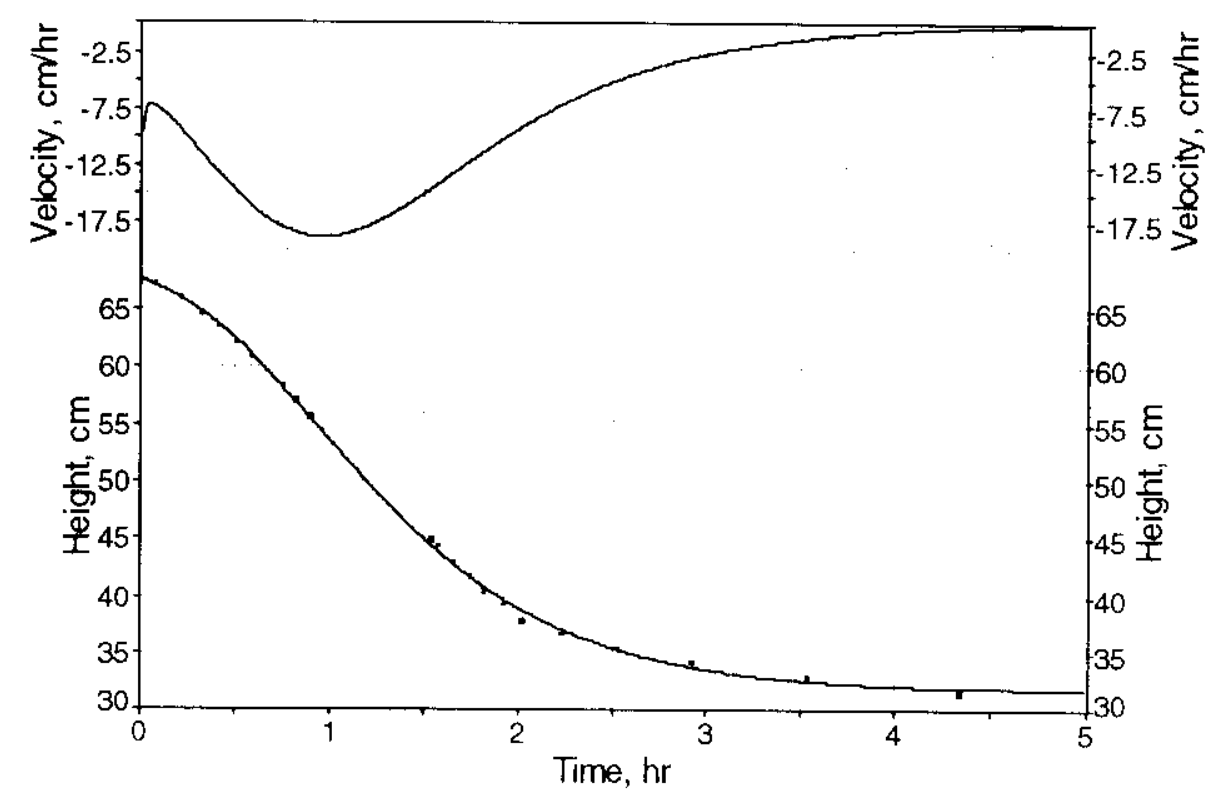

S-107 Water Wash 1 - miniplant

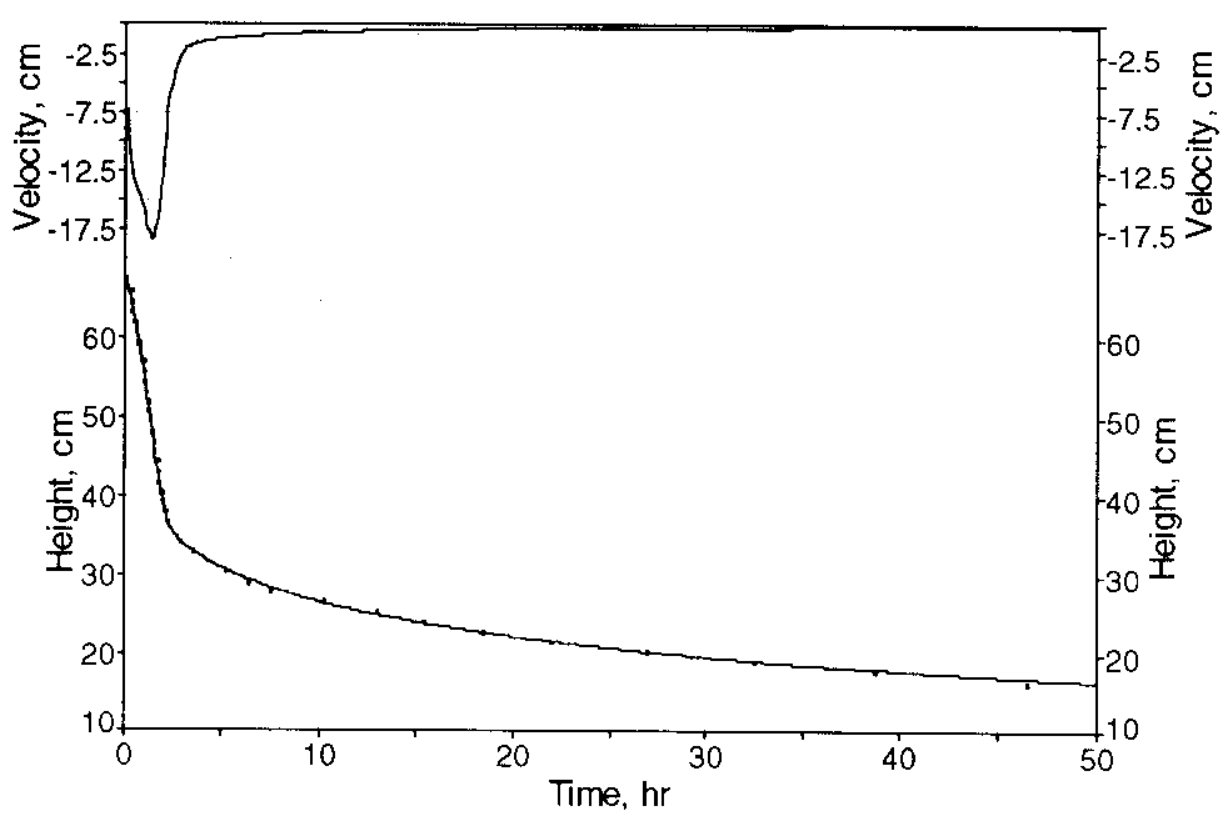

S-107 Water Wash 1 Restirred - miniplant 
HNF-5177, Rev. 0

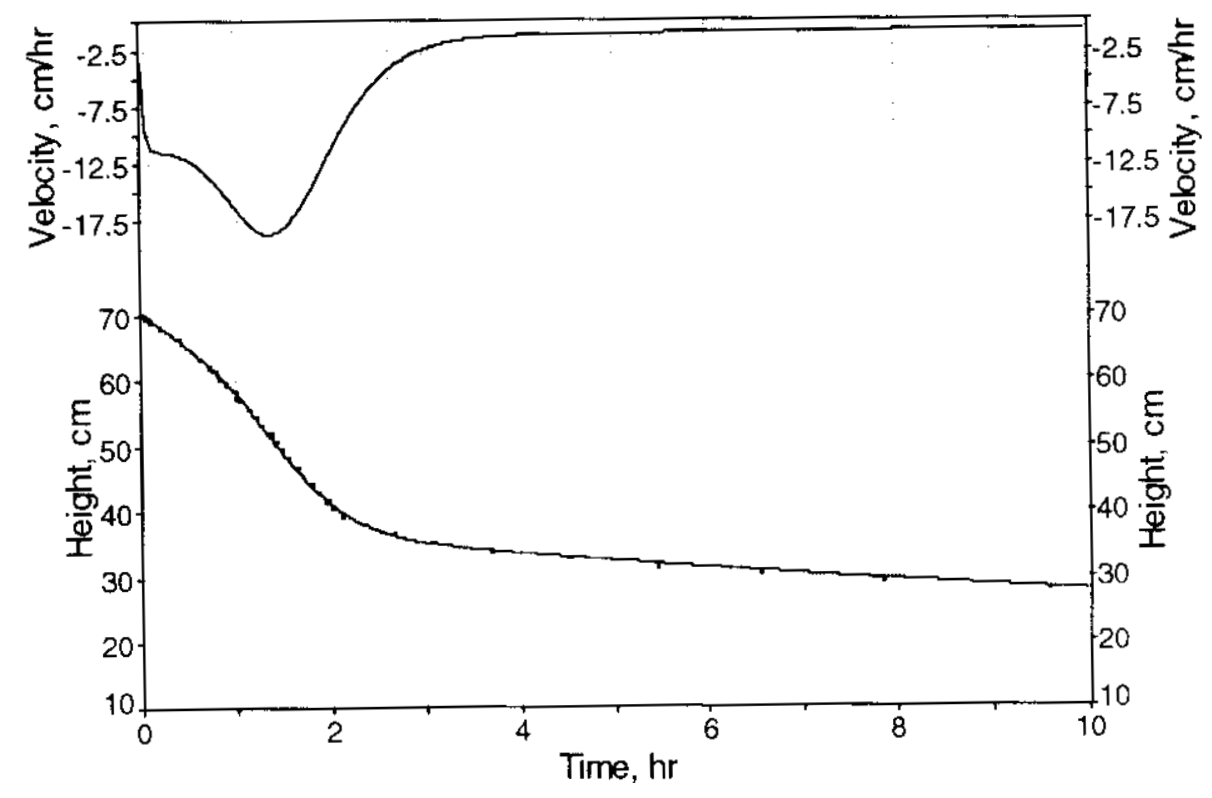

S-107 Water Wash 2 - miniplant

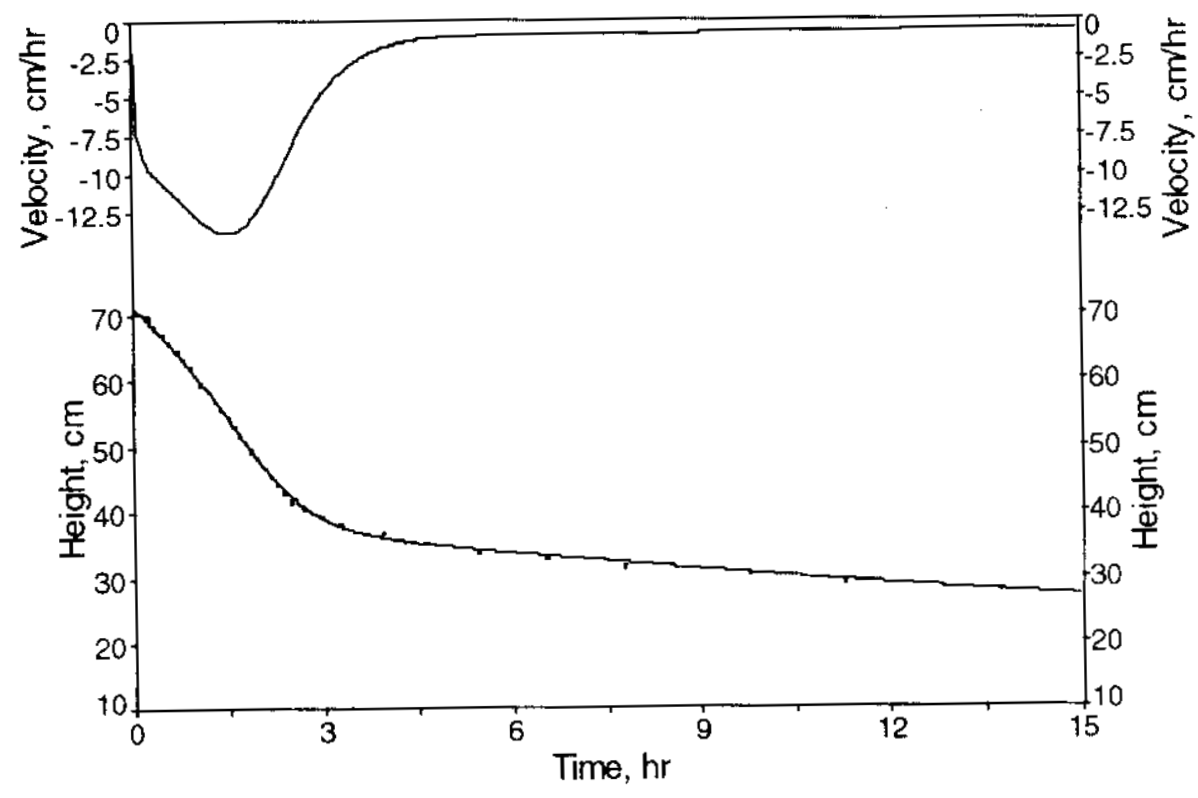

S-107 Water Wash 3 - miniplant 
HNF-5177, Rev. 0

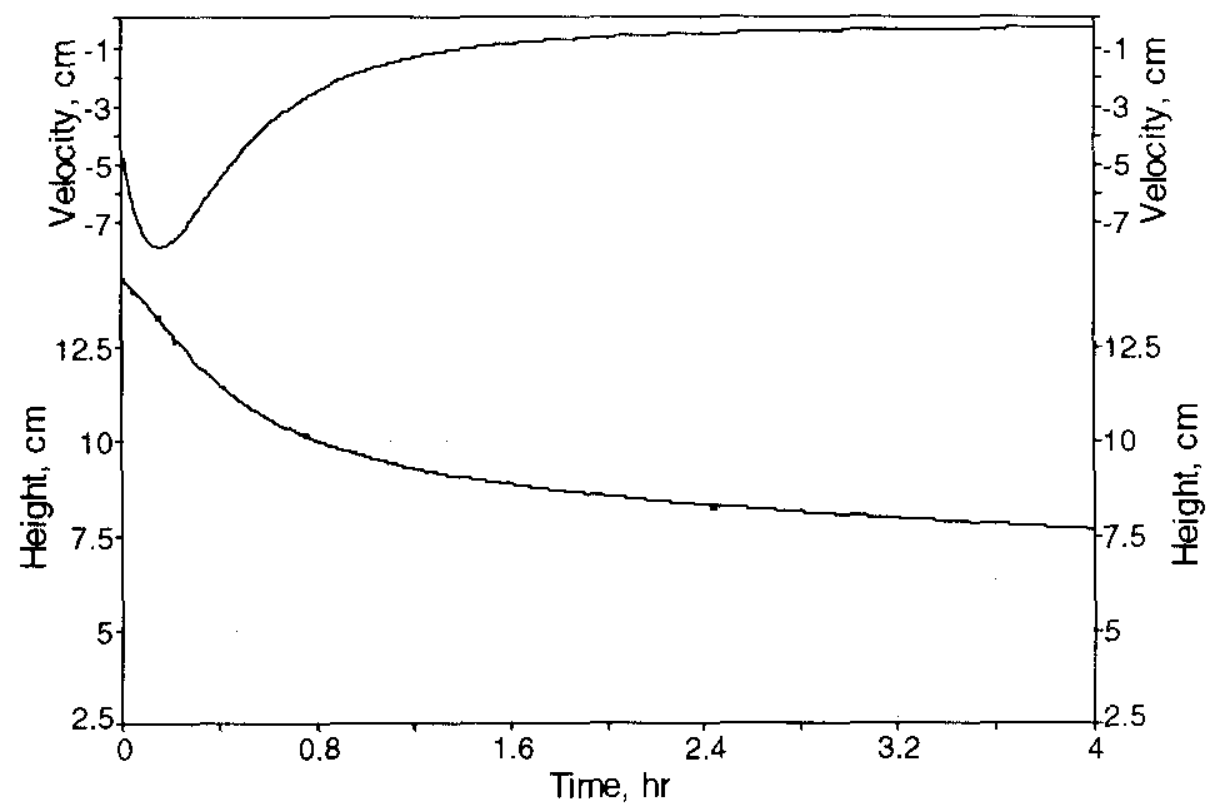

S-107 Extended Caustic Leach - miniplant

B-12 
HNF-5177, Rev. 0

\section{APPENDIX C \\ TANK WASTE SETTLING TESTS \\ PACIFIC NORTHWEST NATIONAL LABORATORY SMALL SCALE}


HNF-5177, Rev. 0

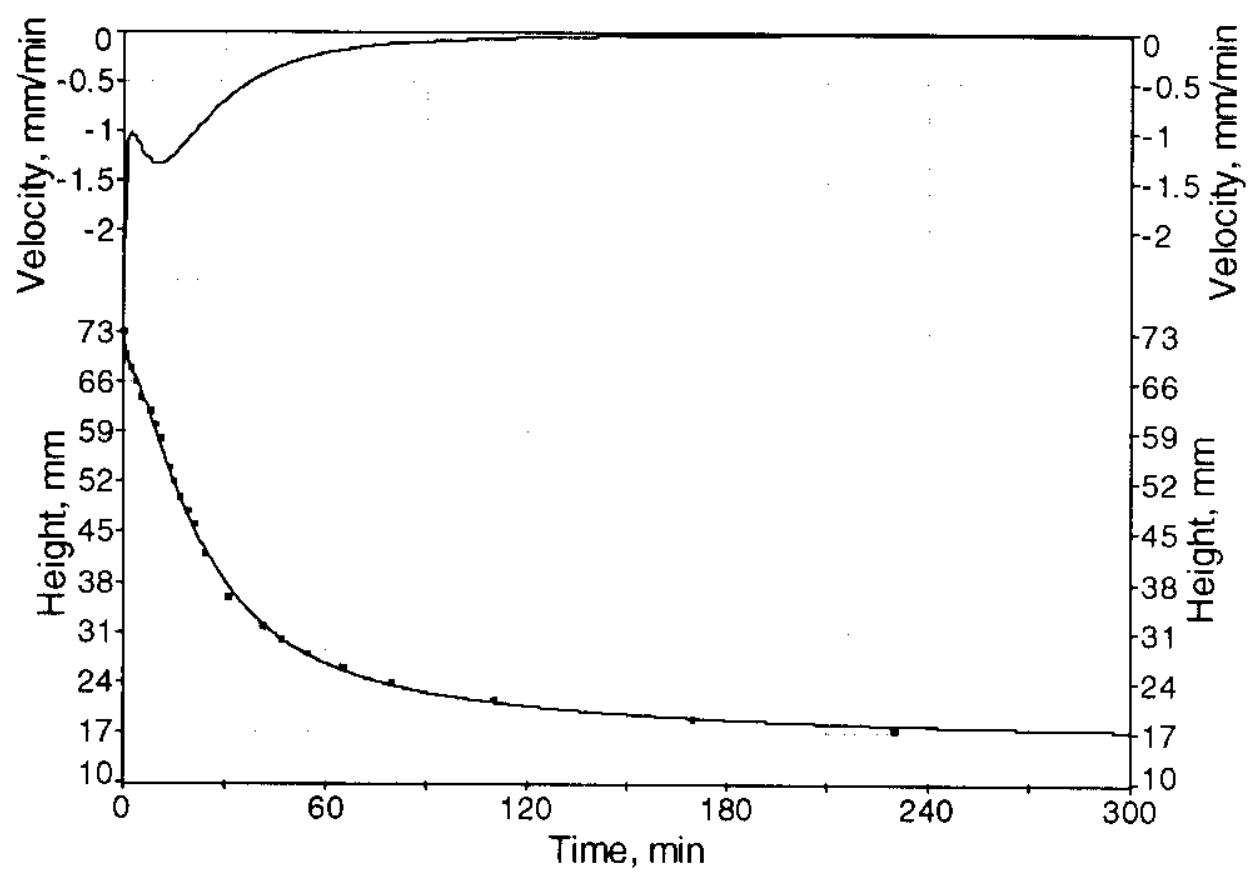

AZ Sludge 1M Caustic Leach - small scale

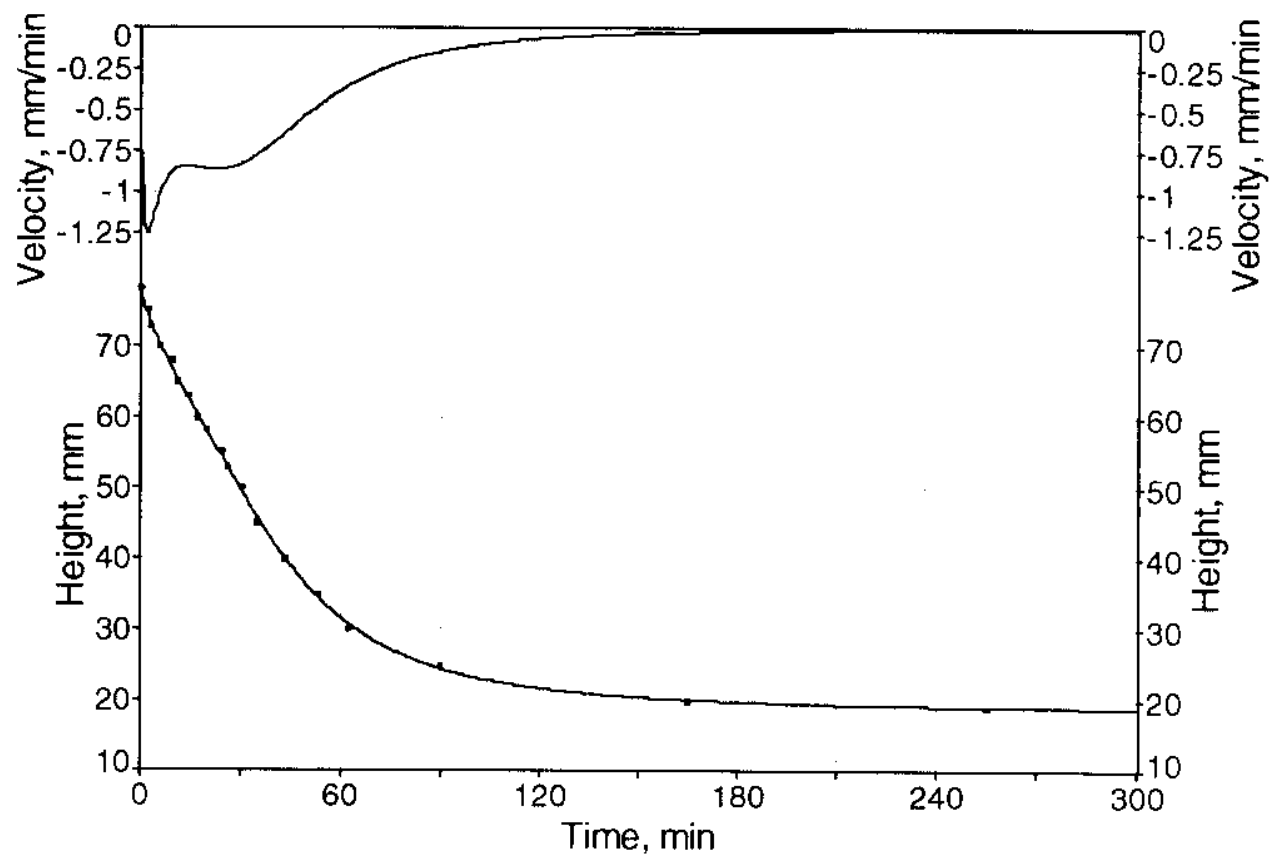

AZ Sludge 2M Caustic Leach - small scale

C- 1 
HNF-5177, Rev. 0

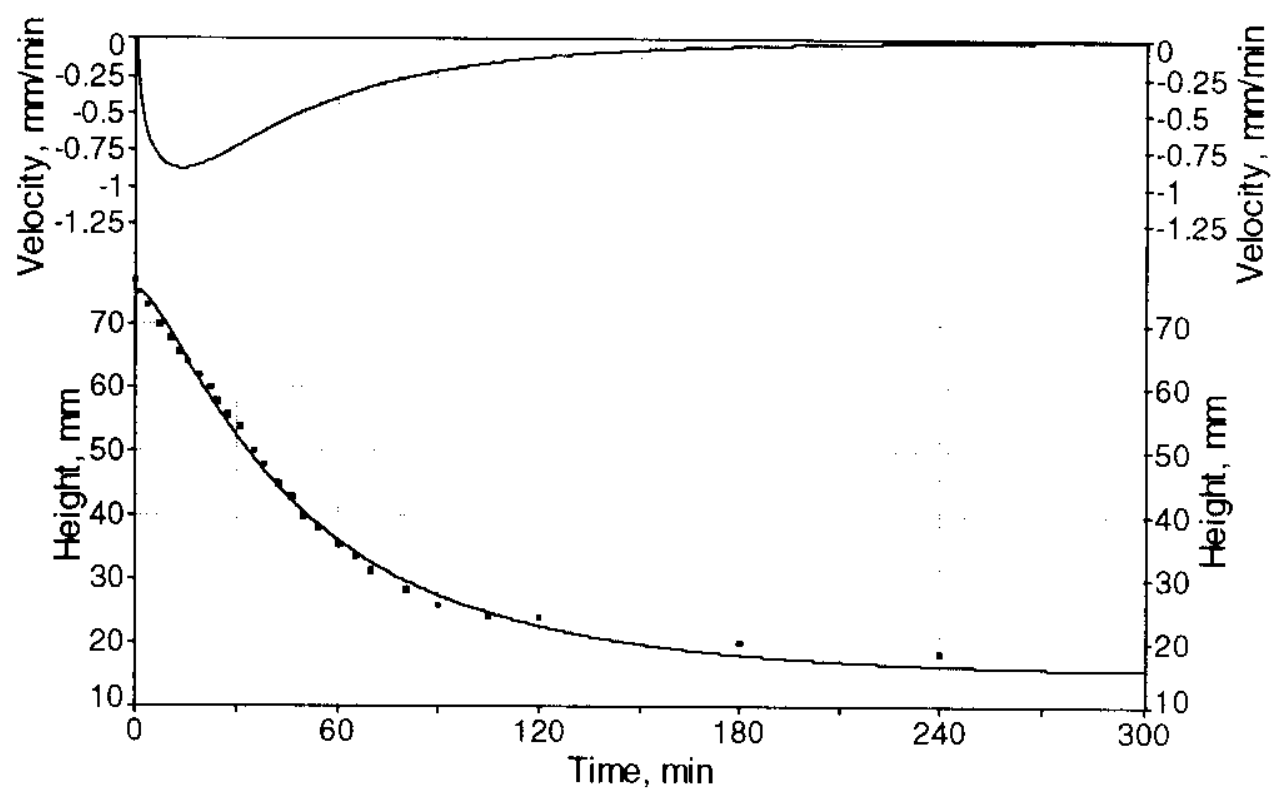

AZ Sludge 3M Caustic Leach - small scale

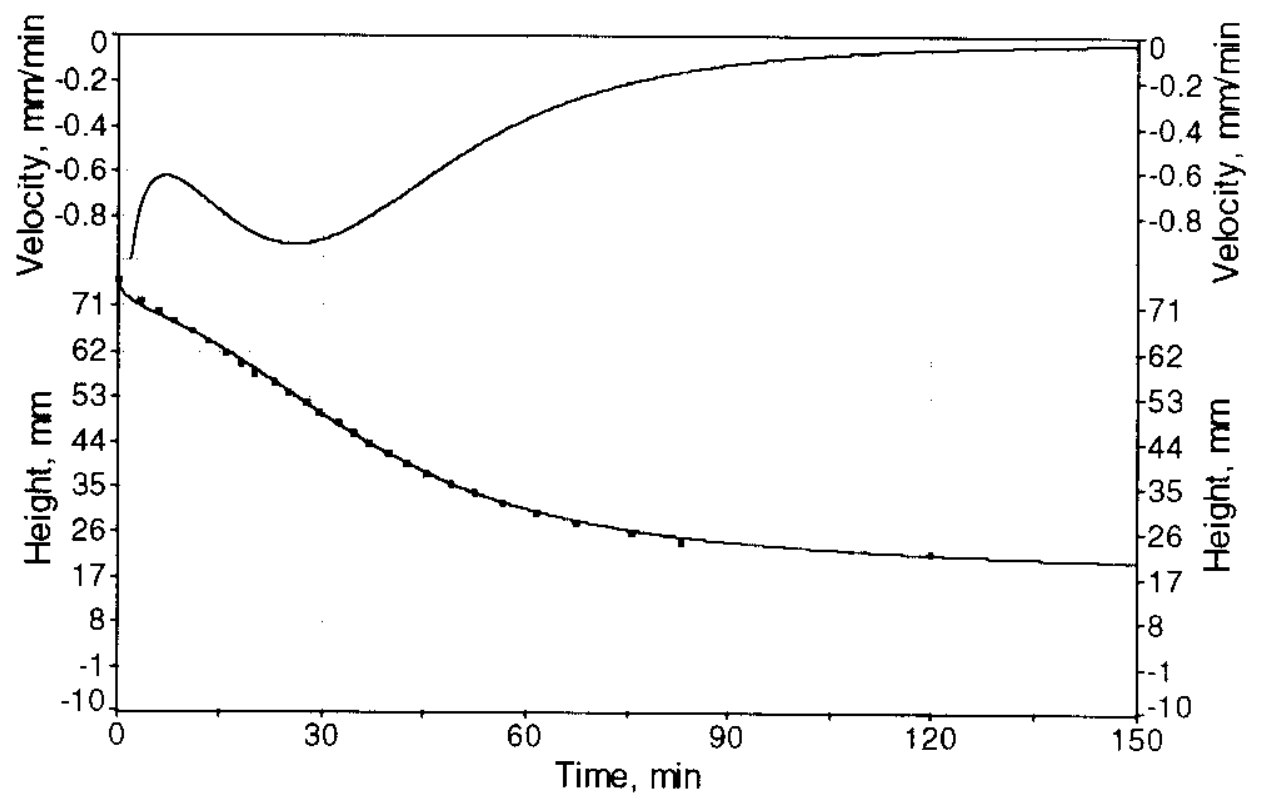

AZ Sludge Second 3M Caustic Leach - small scale 
HNF-5177, Rev. 0

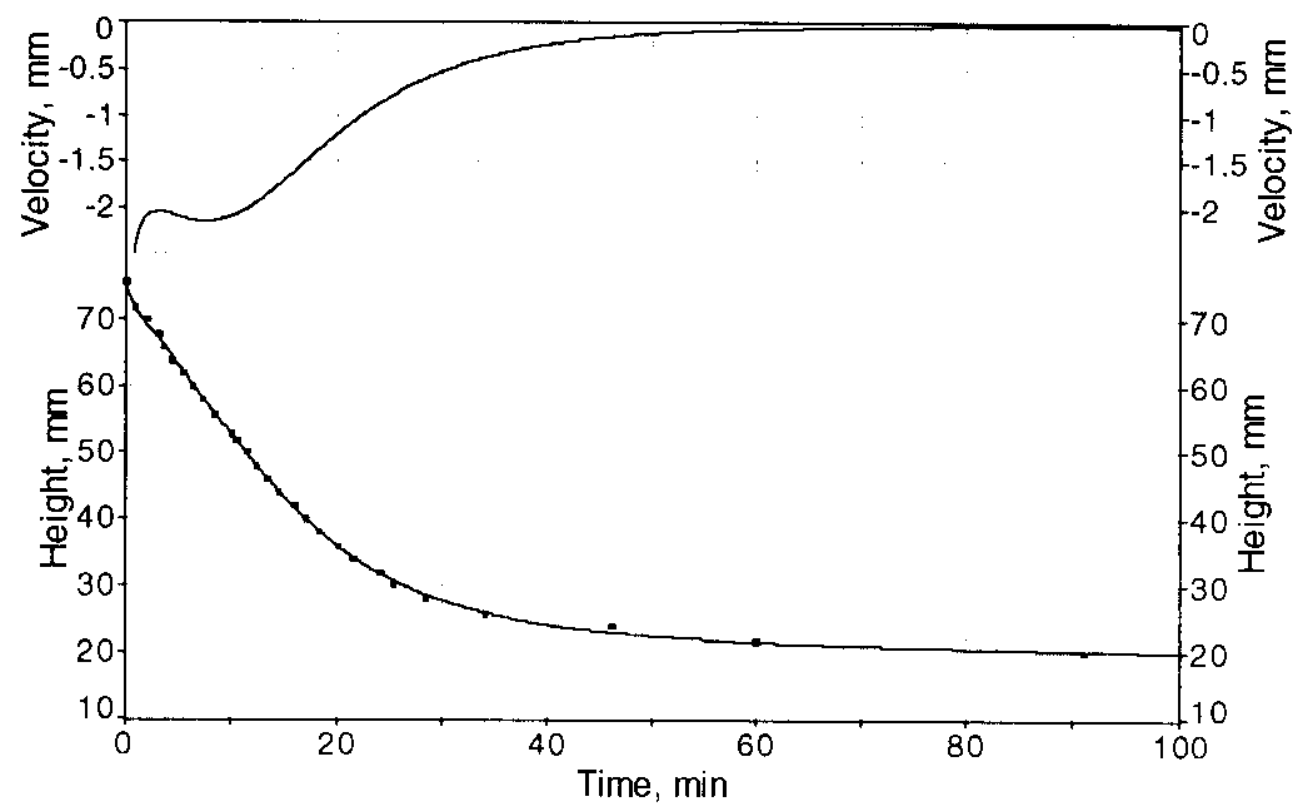

AZ Sludge First Water Wash - small scale

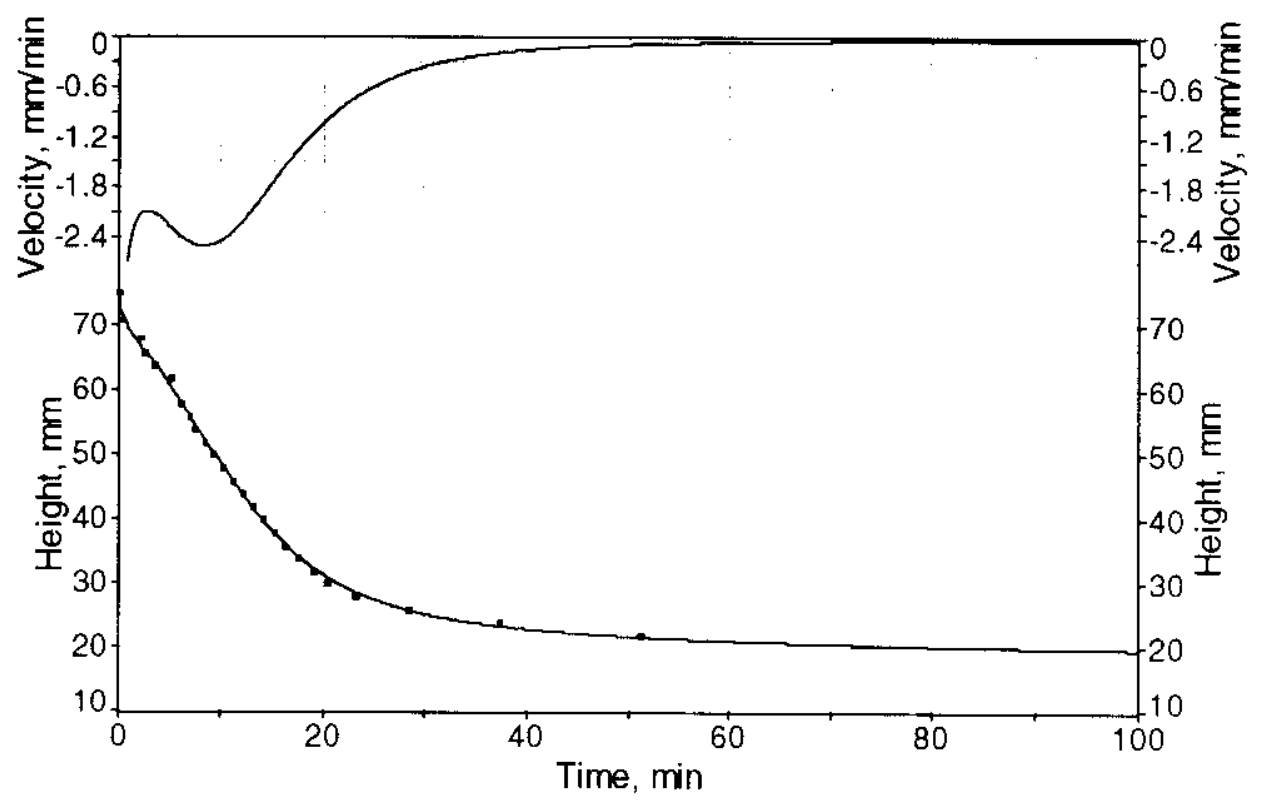

AZ Sludge Second Water Wash - small scale 
HNF-5177, Rev. 0

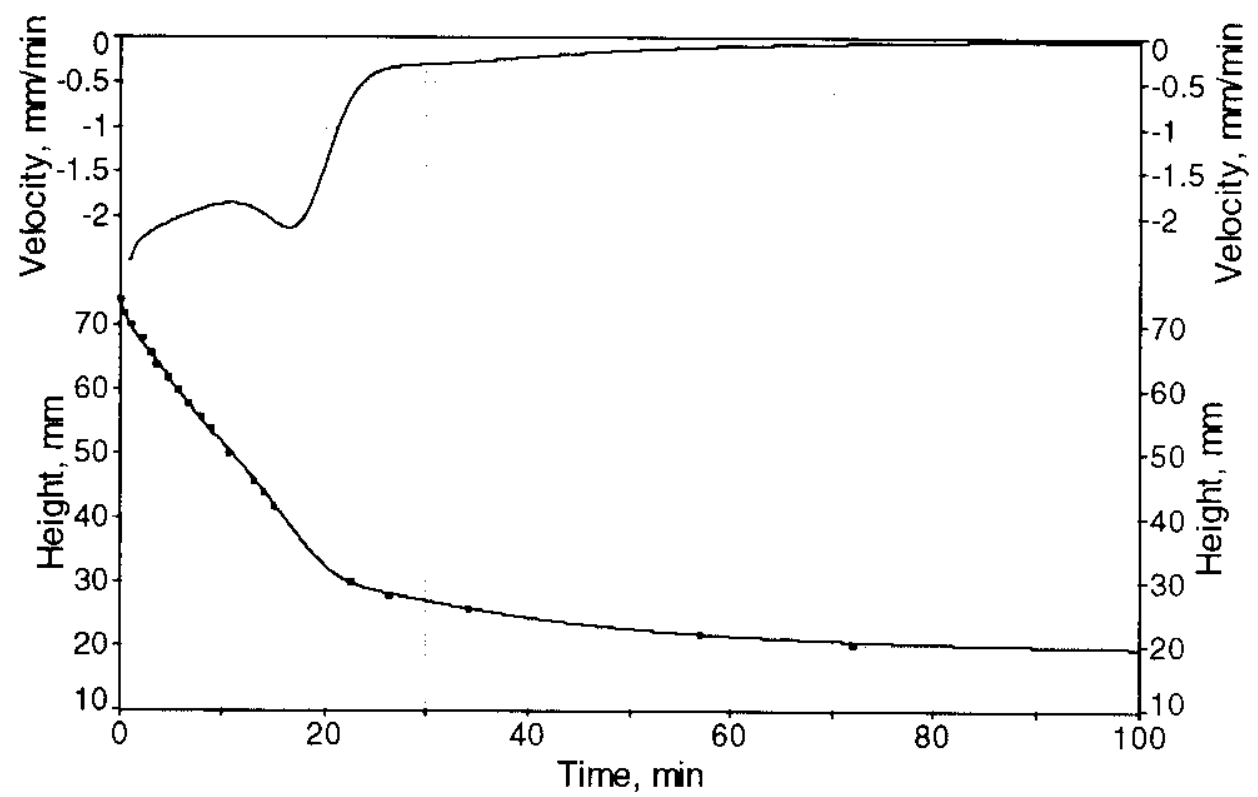

AZ Sludge Third Water Wash - small scale

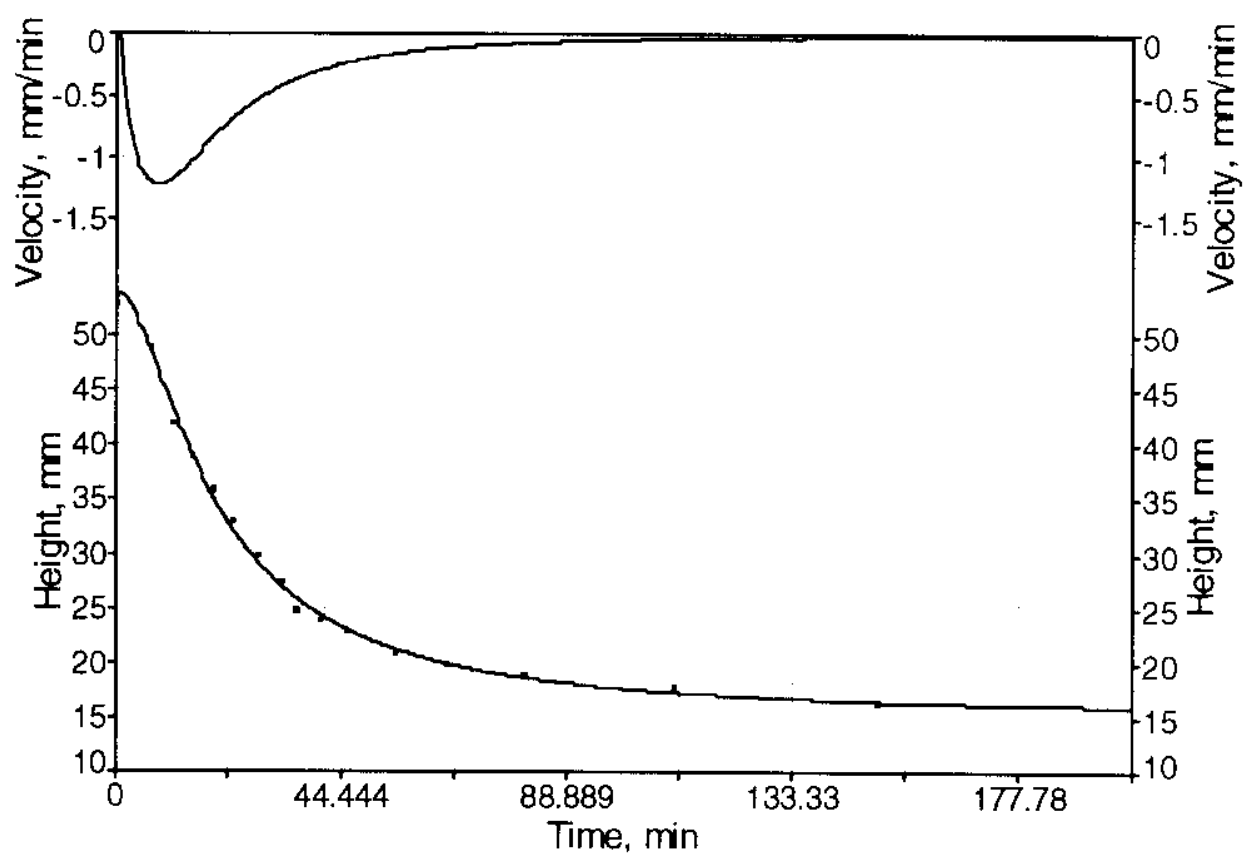

BY-104 First Caustic Leach - small scale 
HNF-5177, Rev. 0

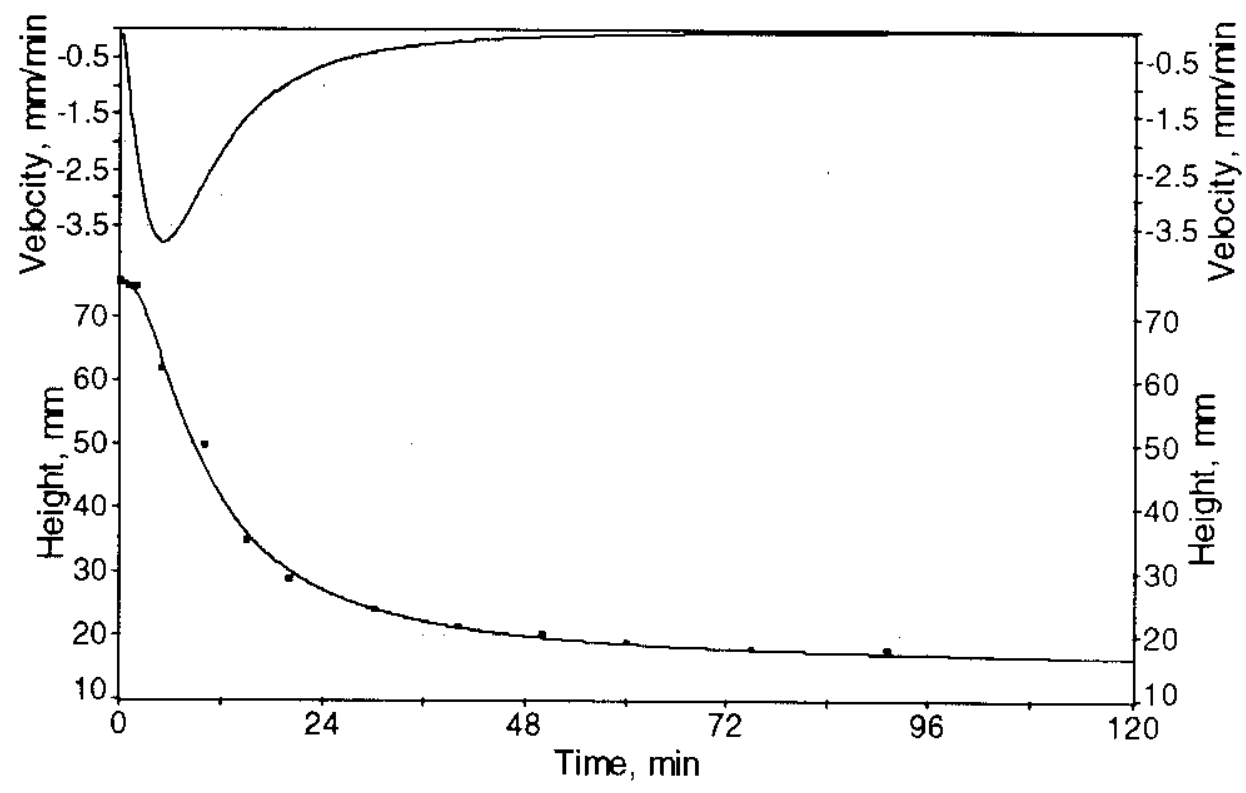

BY-104 Second Caustic Leach - small scale

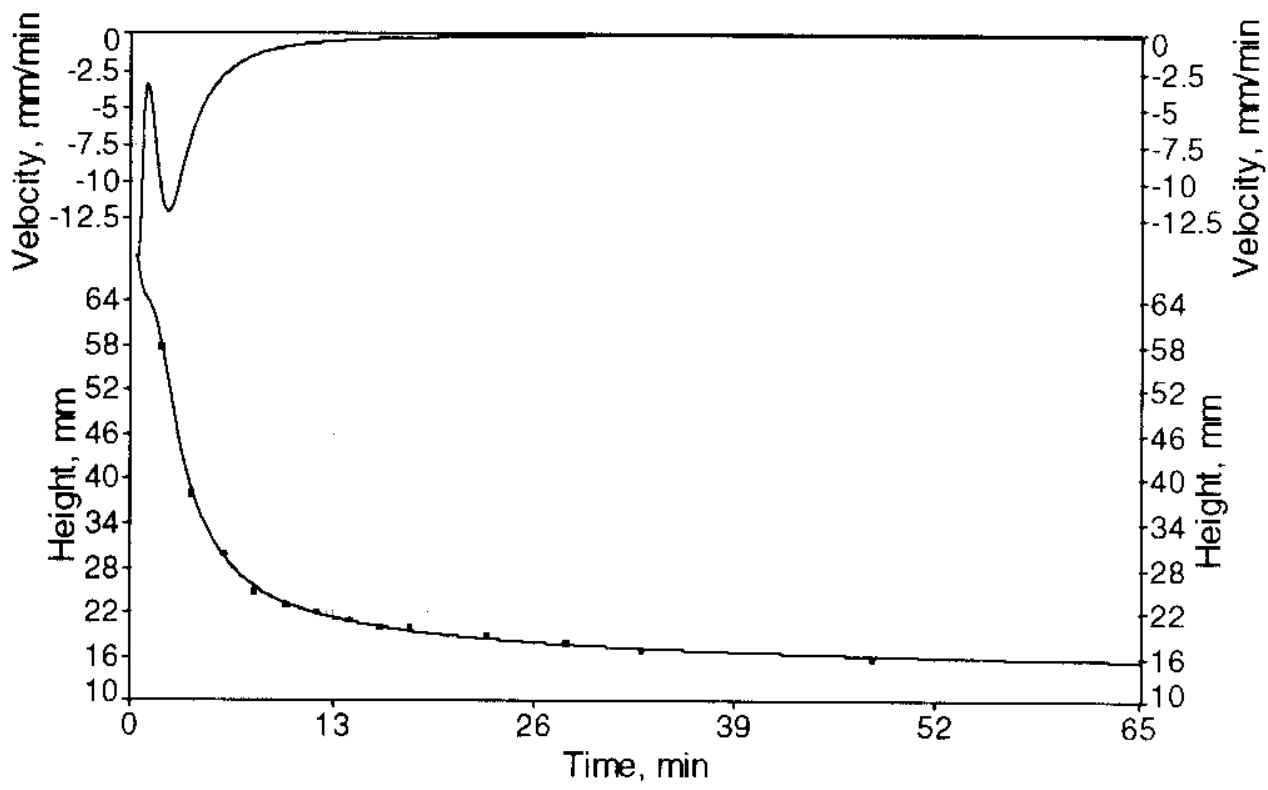

BY-104 First Water Wash - small scale 
HNF-5177, Rev. 0

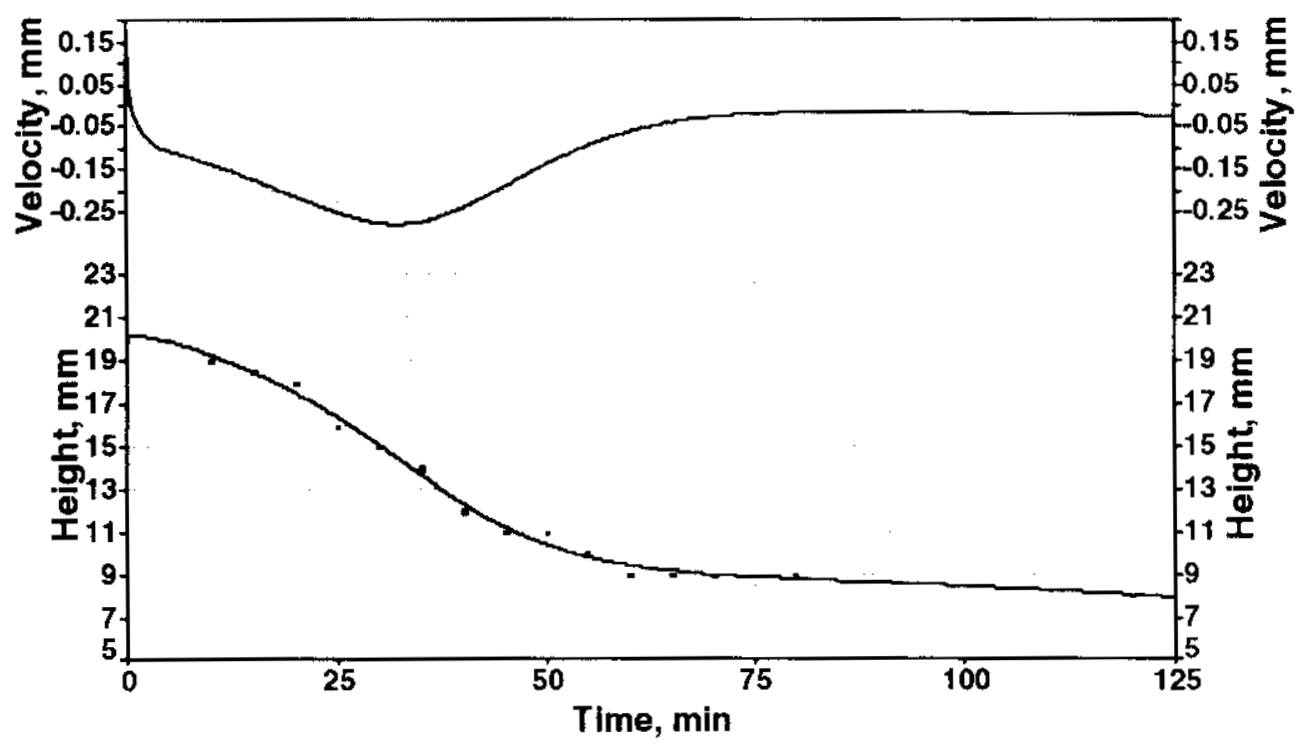

BY-110 First Caustic Leach - small scale

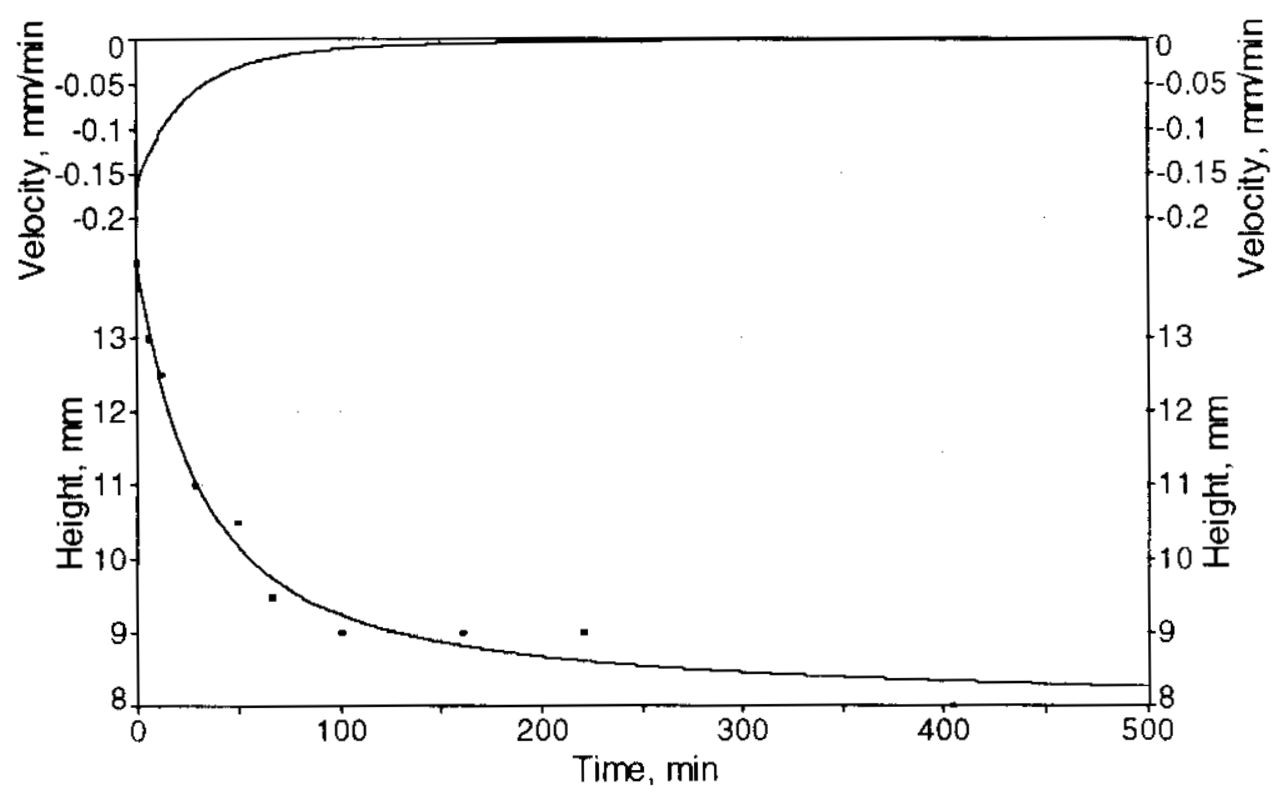

BY-110 First Water Wash - small scale 
HNF-5177, Rev. 0

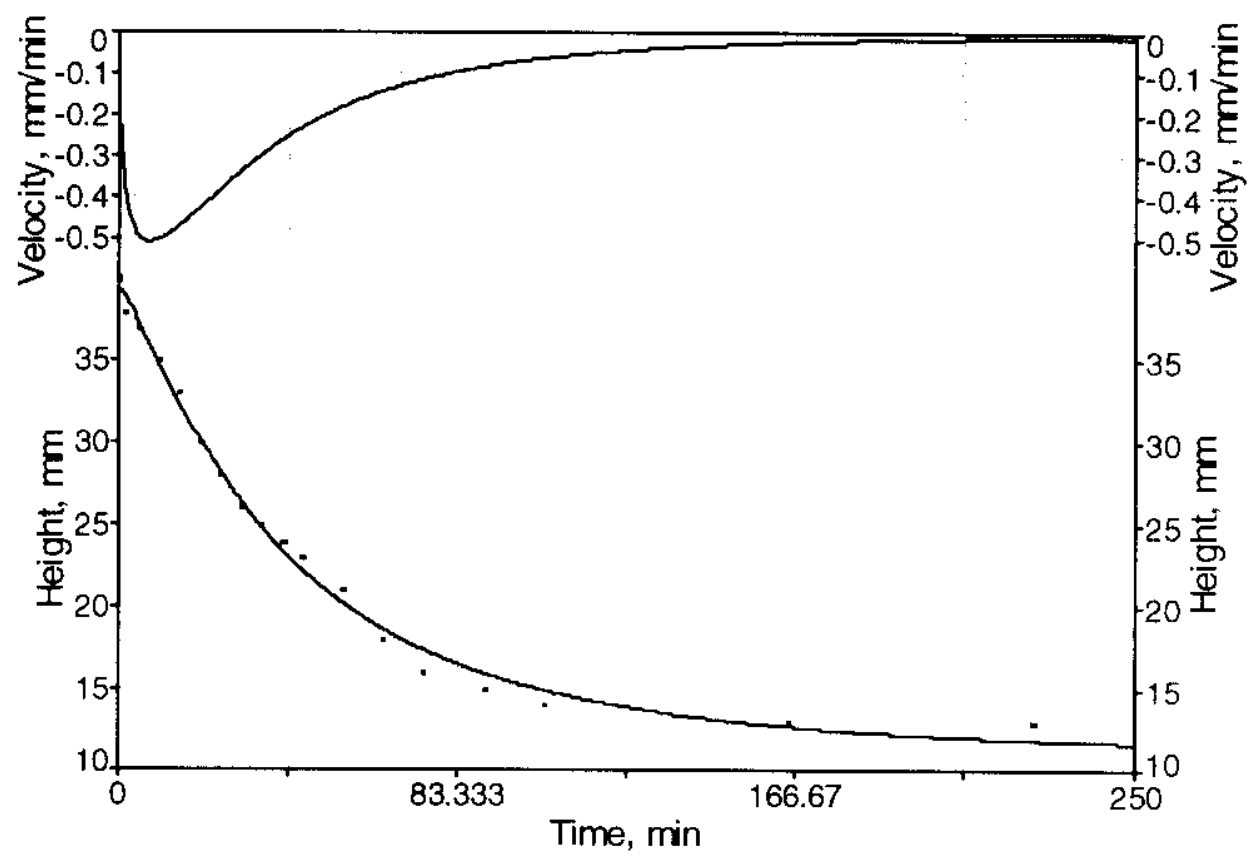

C-106 Second Caustic Leach - small scale

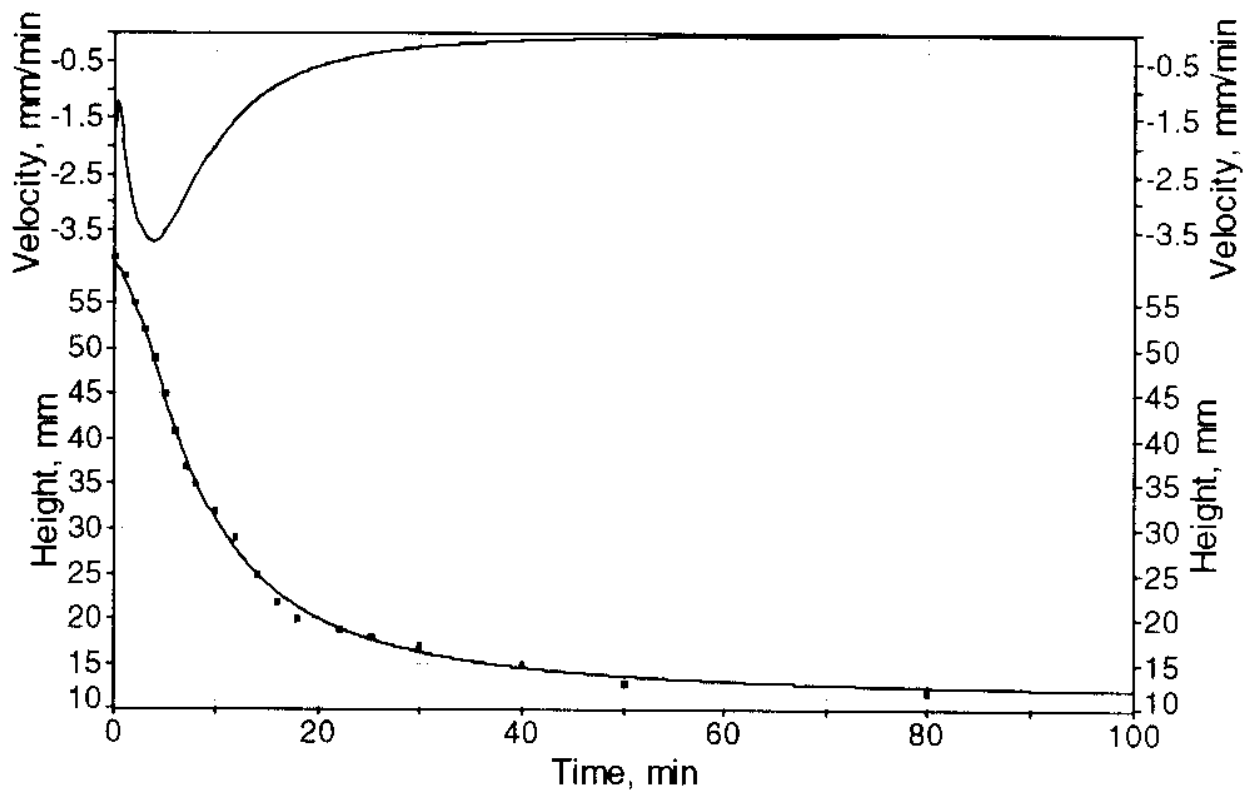

C-106 First Water Wash - small scale 
HNF-5177, Rev. 0

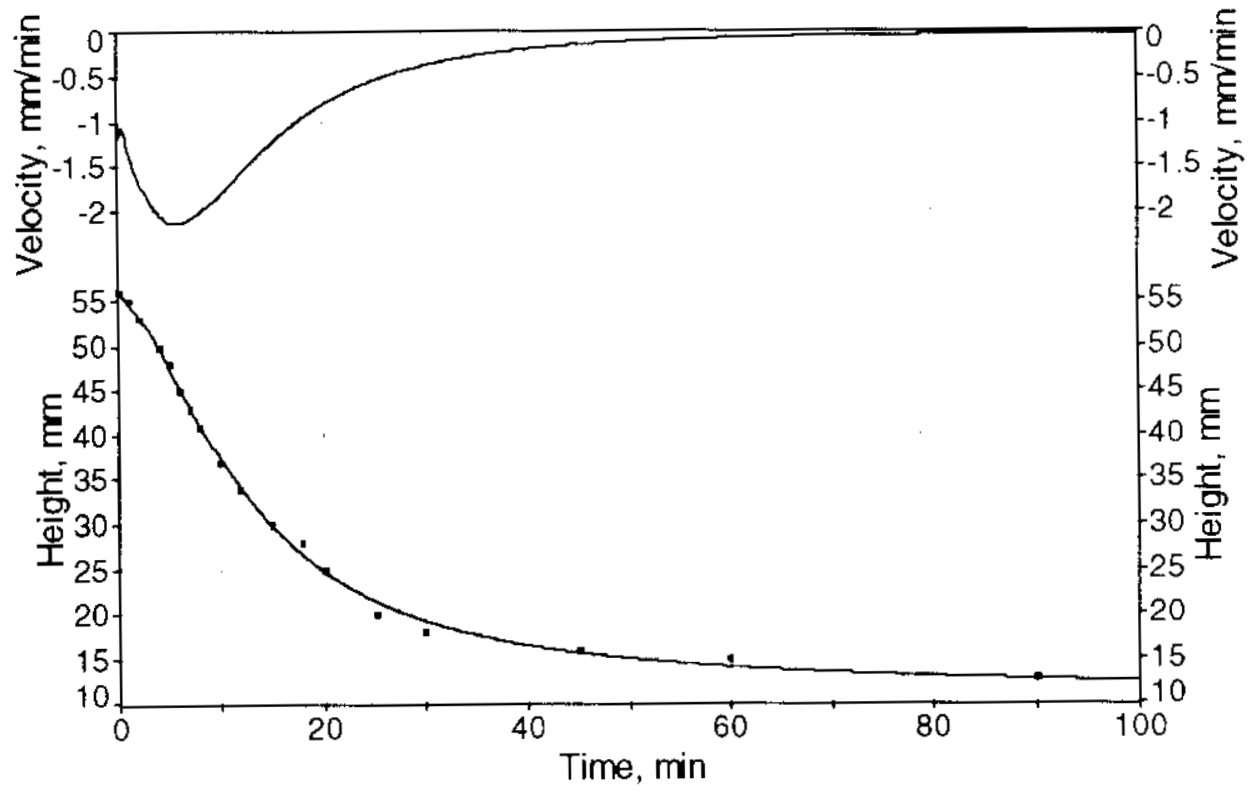

C-106 Second Water Wash - small scale

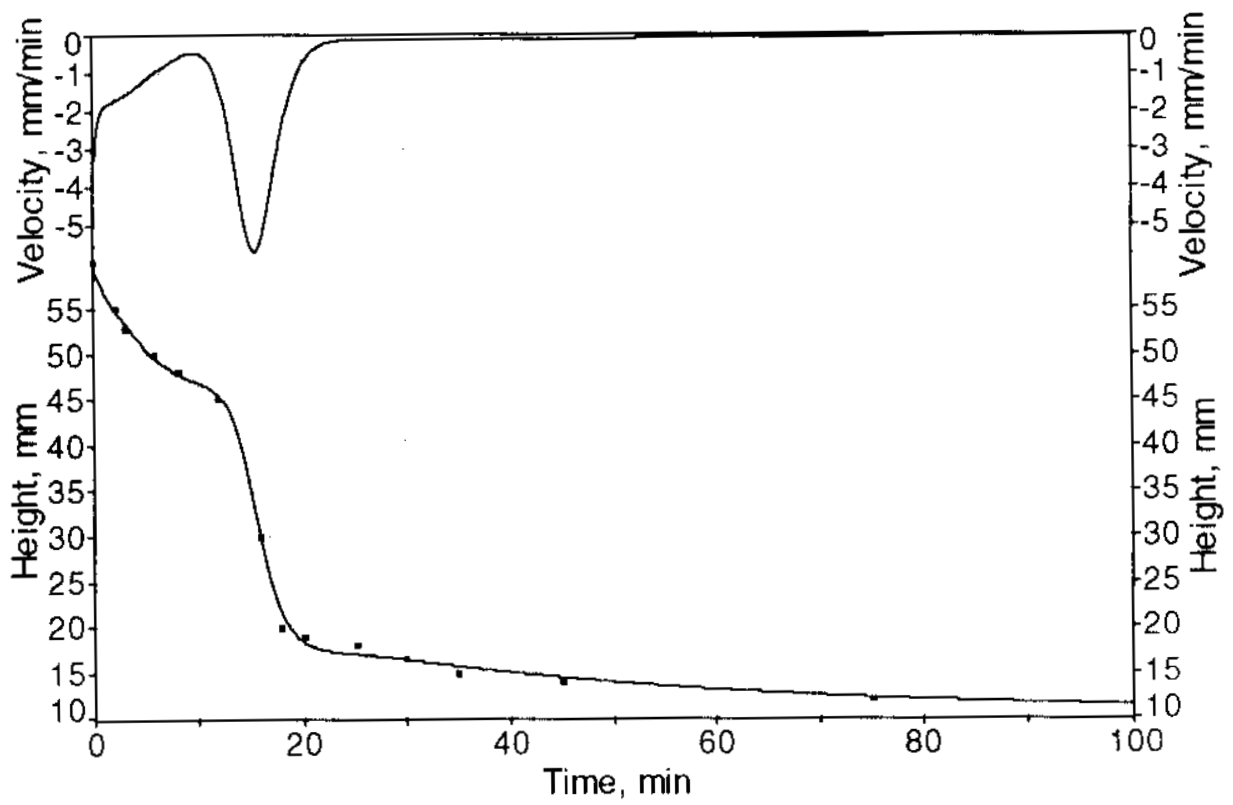

C-106 Third Water Wash - small scale 
HNF-5177, Rev. 0

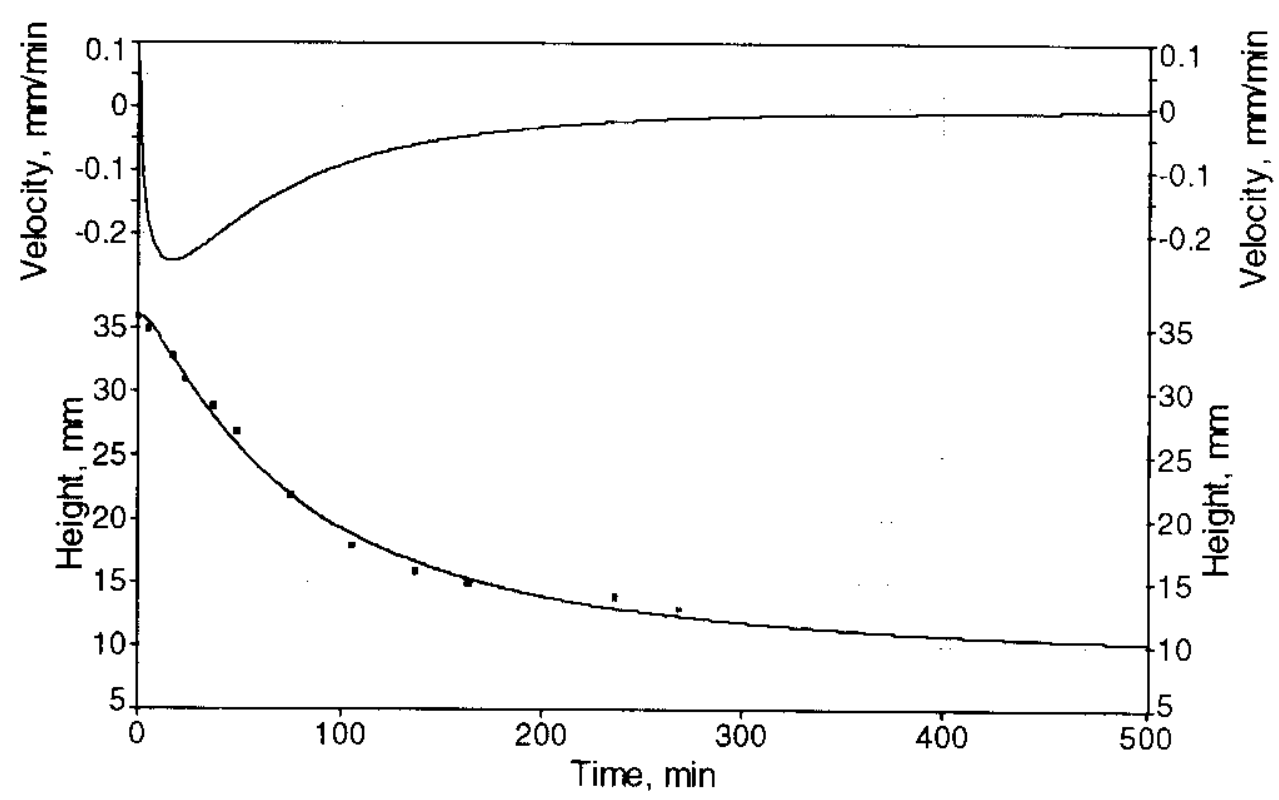

S-107 First Causlic Leach - small scale

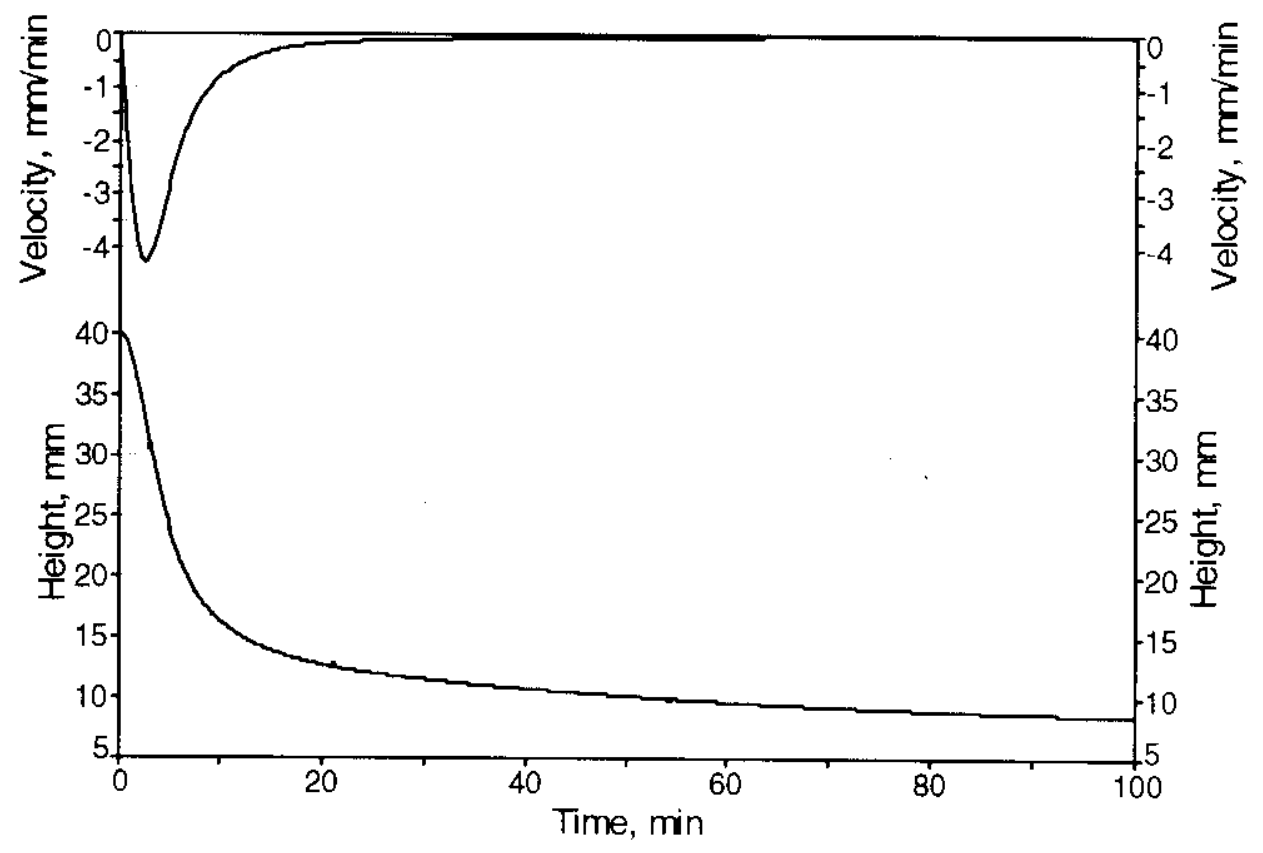

S-107 First Water Wash - small scale 


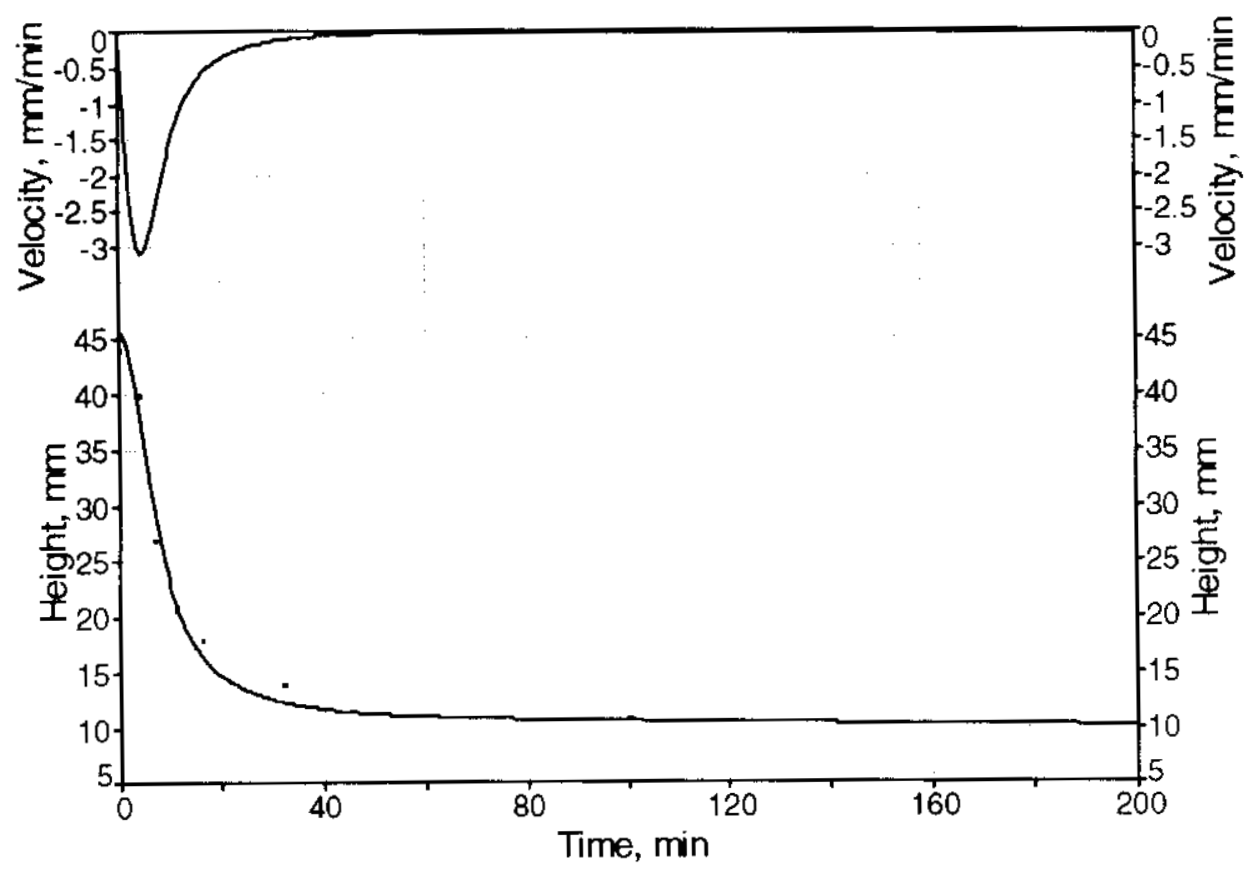

S-107 Second Water Wash - small scale

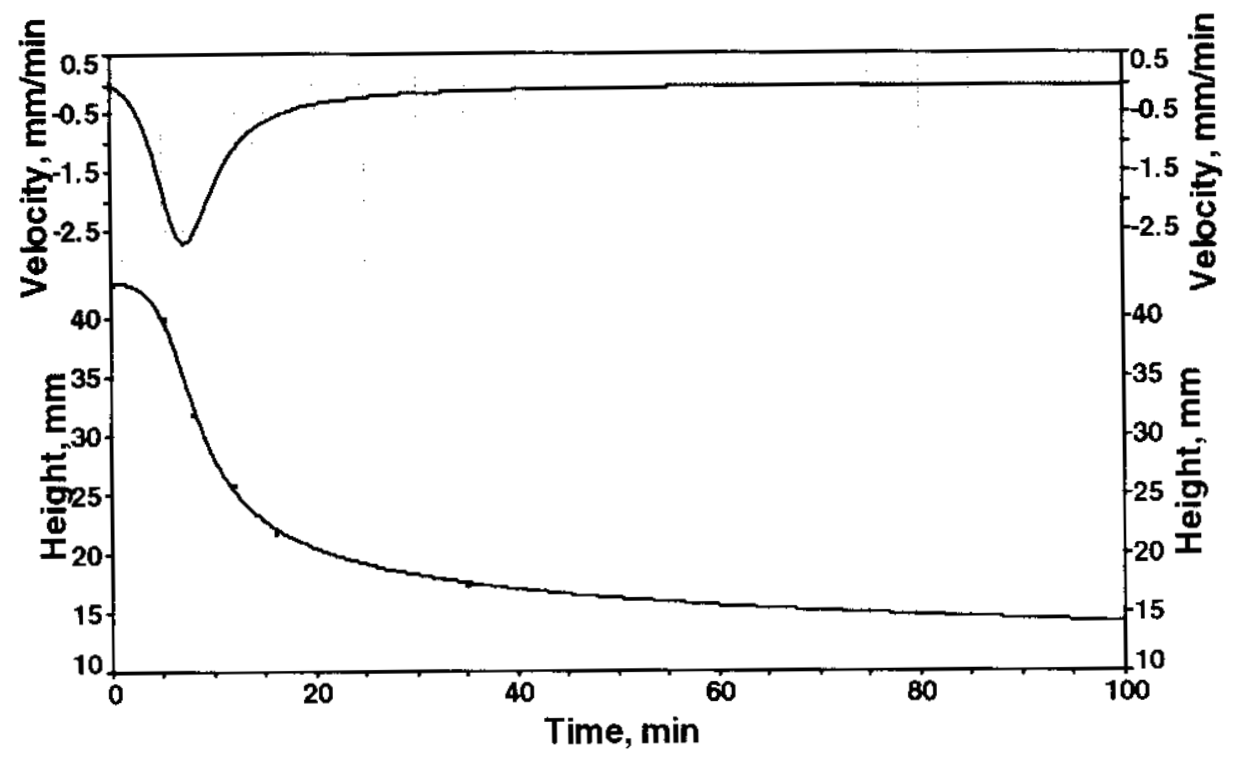

S-107 Third Water Wash - small scale 
HNF-5177, Rev. 0

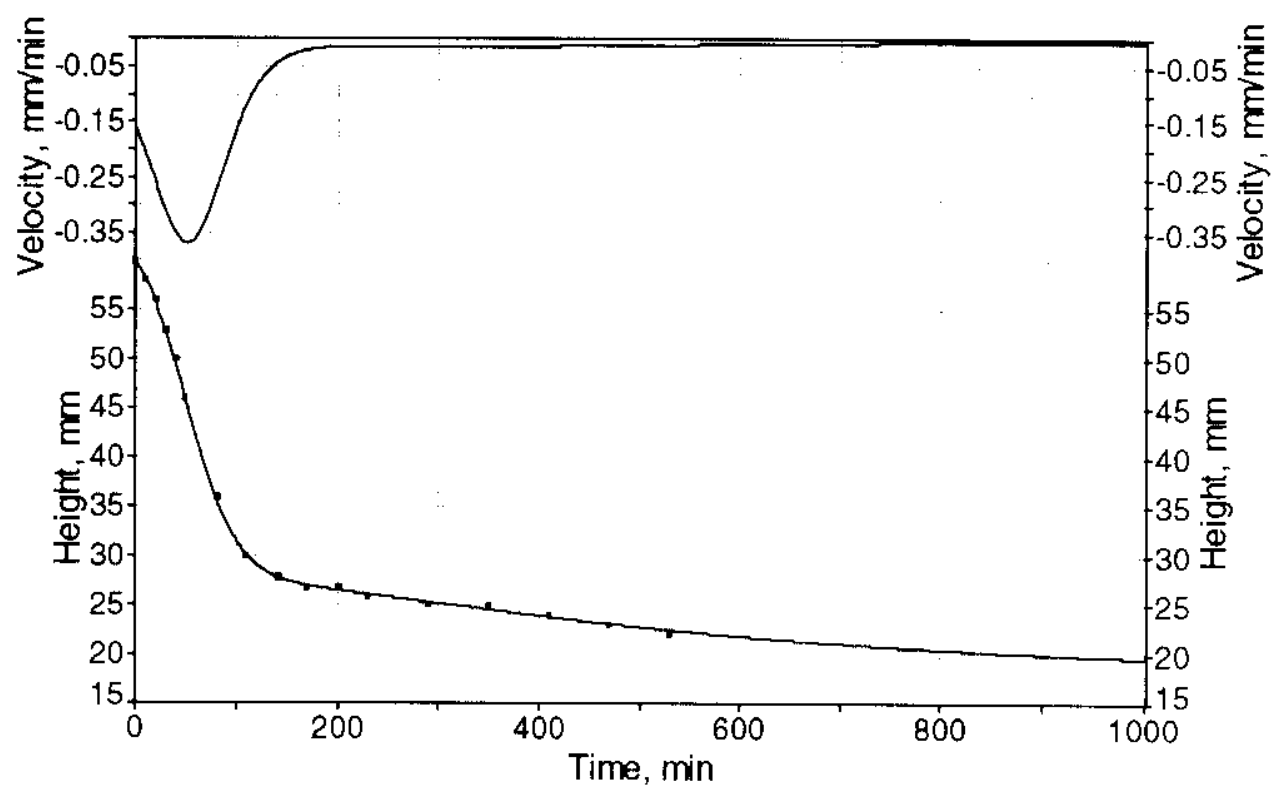

SX-108 First Caustic Leach - small scale

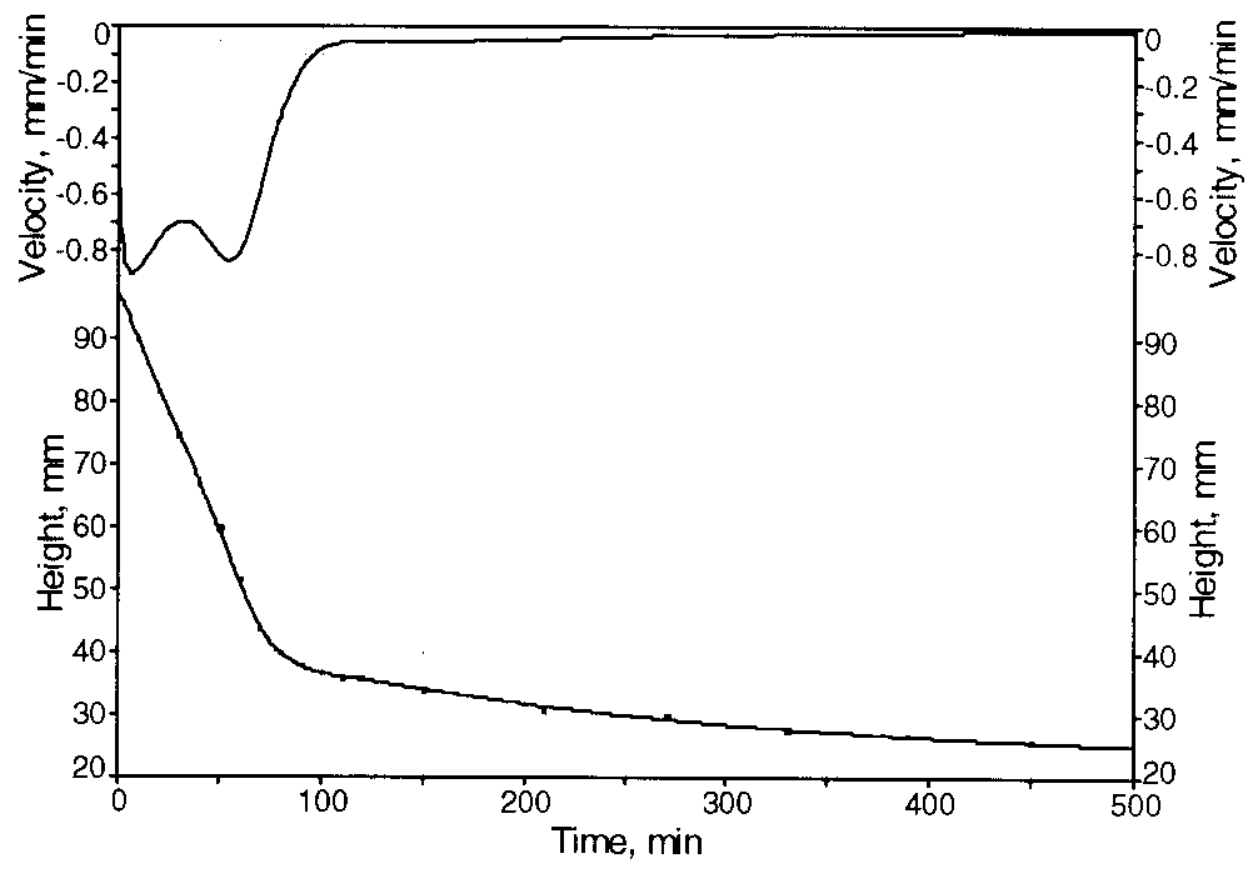

SX-108 Second Caustic Leach - small scale 
HNF-5177, Rev. 0

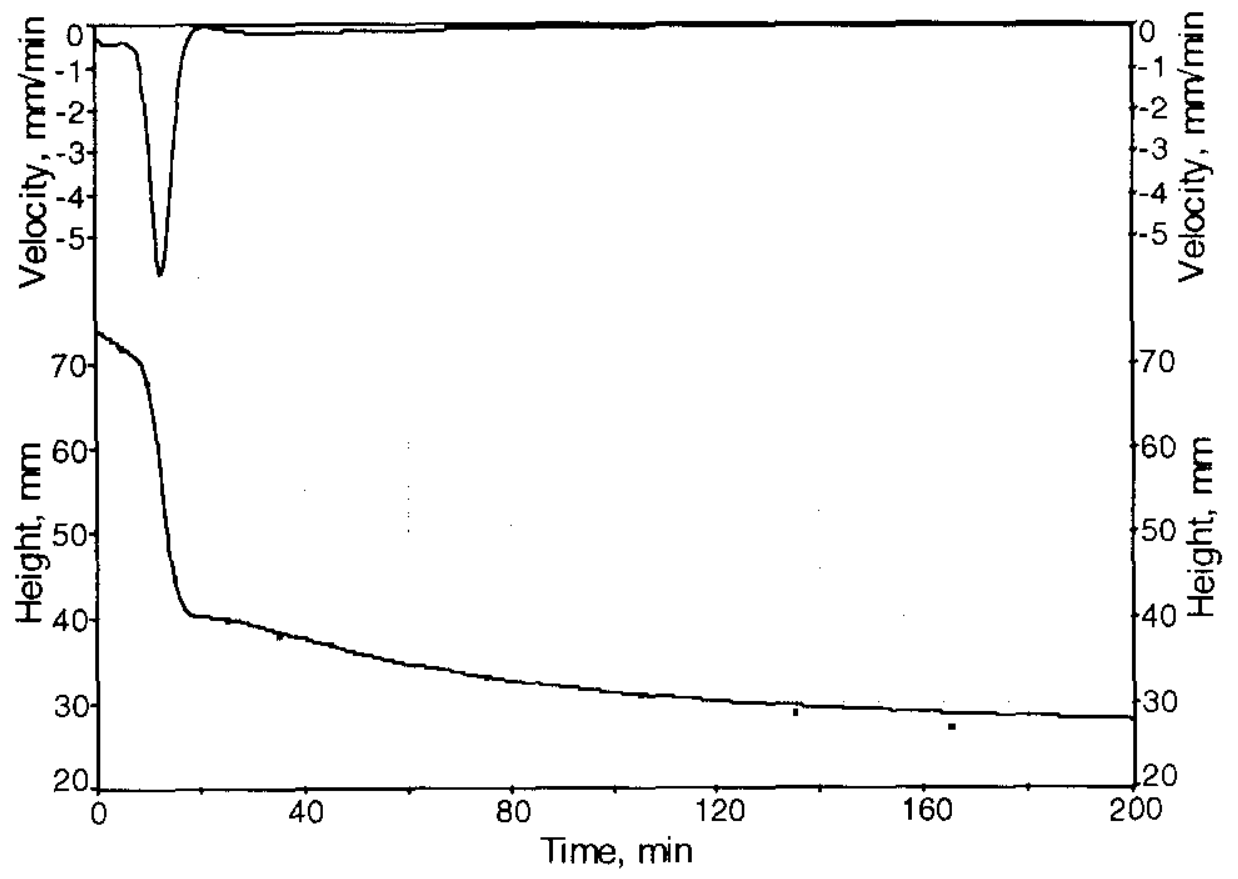

SX-108 First Water Wash - small scale 



\section{DISTRIBUTION SHEET}

To

Distribution

Project Title/Work Order

The settling and Compaction of Nuclear waste slurries, HNF-5177, Rev. 0

\section{Name}

ONSITE

Central Files

DOE Reading Room

DIMC

E. G. Baker

J. H. Baldwin

W. B. Barton

K. P. Brooks

A. B. Carlson

P. J. Certa

A. F. Choho

J. R. Frederickson

D. E. Gana

J. S. Garfield

P. W. Gibbons

D. B. Graves

D. L. Herting

K. M. Hodgson

T. M. Hohl

N. W. Kirch

R. A. Kirkbride

W. L. Kuhn

G. J. Lumetta

R. M. Orme

D. E. Place

B. M. Rapko

D. R. Rector

D. A. Reynolds

K. Sathyanarayana

M. J. Schiebe

\section{From}

G. T. MacLean

MSIN

Text

\begin{tabular}{|c|c|c|c|}
$\begin{array}{c}\text { Text } \\
\text { With All } \\
\text { Attach. }\end{array}$ & Text Only & $\begin{array}{c}\text { Attach./ } \\
\text { Appendix } \\
\text { Only }\end{array}$ & $\begin{array}{c}\text { EDT/ECN } \\
\text { Only }\end{array}$ \\
\hline
\end{tabular}

Page 1 of 2

Date October 28, 1999

EDT No. 625294
EDTNo. 6

\begin{tabular}{|c|c|l|l|l|} 
& & & & \\
\hline B1-07 & $x$ & & & \\
\hline R2-53 -41 & $x$ & & & \\
\hline
\end{tabular}




\section{DISTRIBUTION SHEET}

\begin{tabular}{|l|l|}
\hline To & From \\
Distribution & G. T. MacLean \\
\hline
\end{tabular}

Project Title/Work Order

The Settling and Compaction of Nuclear Waste Slurries, HNF-5177, Rev. 0

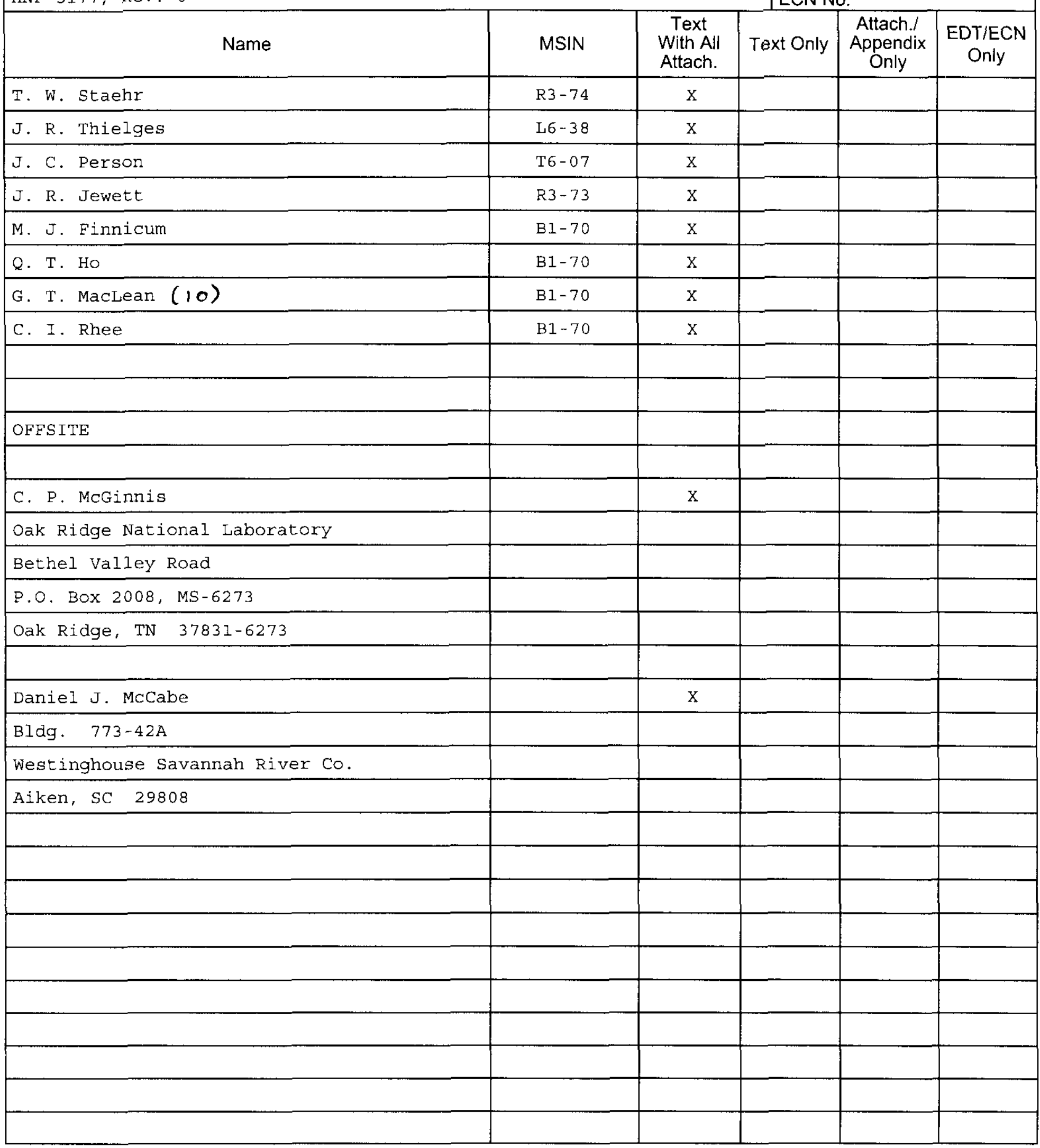

